\title{
EL CONCEPTO DE PODER EN EL NUEVO REINO DE GRANADA EN LOS SIGLOS XVII - XVIII
}

Trabajo de investigación

HISTORIA DE LAS IDEAS

Diana Milena Cárdenas León Universidad Santo Tomás

Facultad de Filosofía y Letras

Maestría en Filosofía Latinoamericana

Bogotá, Diciembre 2016 


\title{
EL CONCEPTO DE PODER EN EL NUEVO REINO DE GRANADA EN LOS SIGLOS XVII - XVIII.
}

Trabajo de investigación

\author{
Tutor \\ Álvaro Acevedo \\ Universidad Santo Tomás \\ Facultad de Filosofía y Letras \\ Maestría en Filosofía Latinoamericana
}

Bogotá, Diciembre 2016 


\section{Tabla de contenido}

Resumen

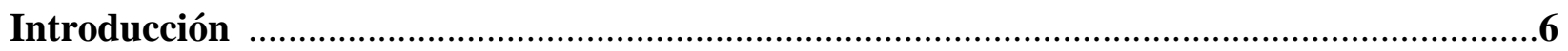

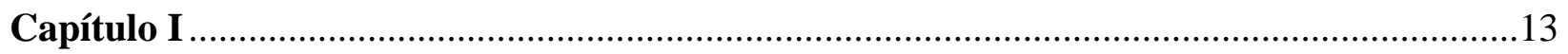

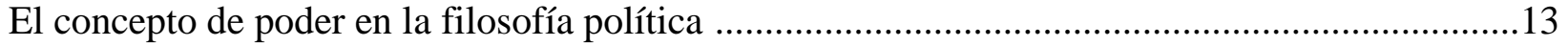

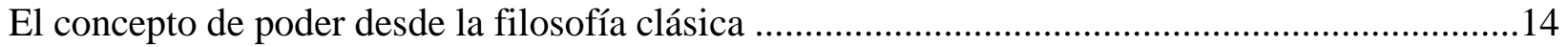

Concepto de poder en la teología medieval ......................................................................20

Concepto de poder desde la visión política medieval .........................................................24

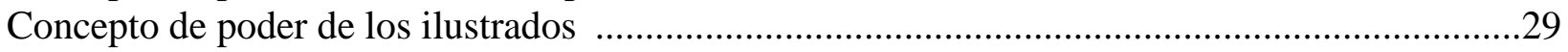

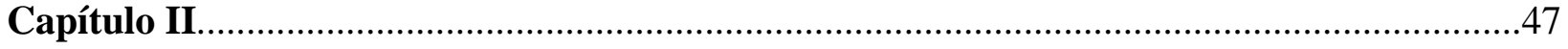

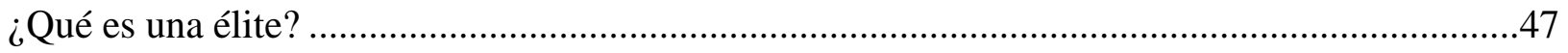

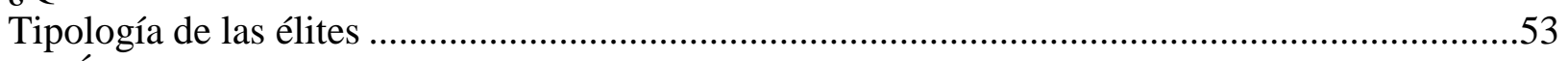

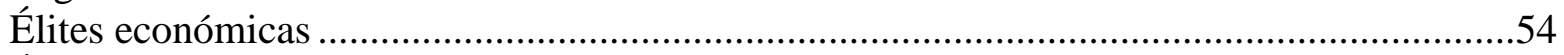

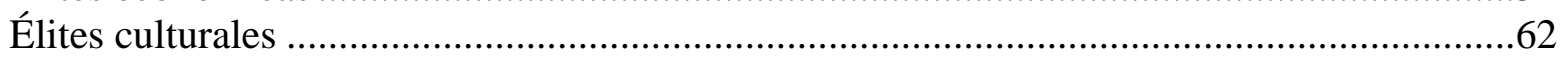

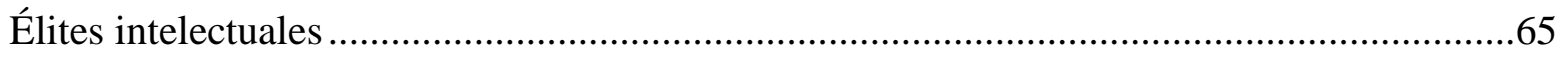

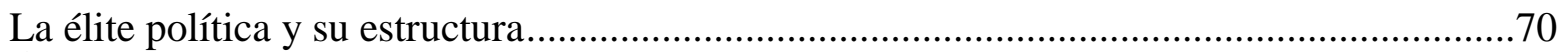

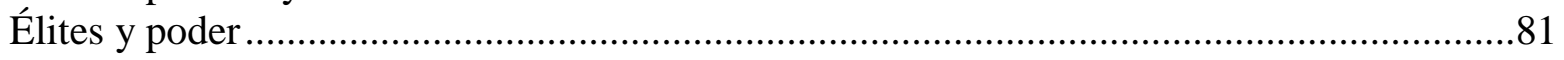

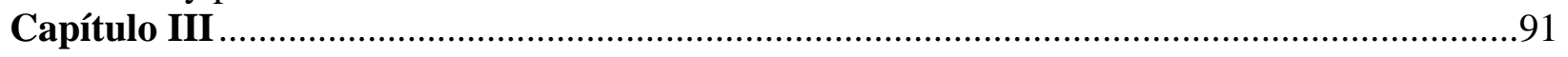

Configuración de las políticas de poder y élite en la

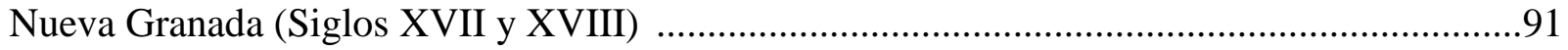

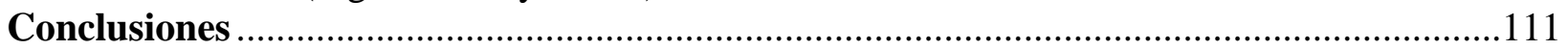

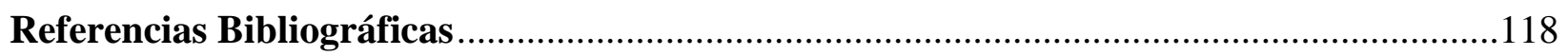




\section{Resumen}

Somos América Latina, continente regido por la historia y los hechos que en ella se han depositado, somos un mundo aparte, pero por partes. Nacimos desde la antigüedad, de una sociedad aborigen, no conocimos las eras antiguas, ni las medievales de manera vivencial, pero desde la llamada modernidad, nos apegamos a la historia de otro continente. Somos fieles a nuestro pasado, pero poco conocemos de él, por ello nos es más fácil entender las guerras médicas y púnicas que lo que eran los incas, los mayas, los aztecas, los muiscas, los aimaras y tantas otras culturas que se desarrollaron en nuestros territorios y que tenían una identidad propia.

Es un continente que ha vivido las guerras, somos el subcontinente donde el ser nosotros está supeditado al ser Europa; muestra de ello son las escalas sociales, los modos políticos, es decir, las fuerzas de poder, que no se diferencian en mayor cosa de las europeas. Nos comprendimos y nos dimos cuenta que éramos diferentes, permitimos que se nos impusieran las reglas que otros, a su parecer, consideraban acordes a nuestra realidad. Forjaron élites intelectuales, económicas, políticas, que ostentaban el poder, y fueron visibles en la Nueva Granada, élites que hicieron surgir a otras con cierto desapego de las ya concebidas desde la llegada del mundo europeo al mundo americano. Son élites intelectuales, culturales y económicas que, fermentan el ideario de que Latinoamérica no es más que lo que la historia nos ha dejado, y lo que tal historia nos ha dejado, comenzó con la llegada de Europa a América.

Palabras clave: élites intelectuales, élites económicas, élites políticas. 


\begin{abstract}
We are Latin America, continent governed by the history and the facts that have been deposited in it, we are a world apart, but in parts. We were born from the antiquity, from an aboriginal society, we did not know the ancient eras, nor the medieval ones in an experiential way, but from the call of modernity, we adhere to the history of another continent. We are faithful to our past, but we know little of it, so it is easier for us to understand the medical and punic wars than the Incas, the Mayans, the Aztecs, the Muiscas, the Aymara, and many other cultures that developed in our territories and that had an identity of their own.

We are the faithful copy of a continent that has lived wars, we are the subcontinent where the being us is subordinated to being Europe, this is shown by the social scales, the political modes, that is to say, the forces of power, which do not differ more than the European ones. We understood each other and realized that we were different, we allowed others to impose rules that they considered compatible with our reality.

These others forged intellectual, economic and political élites, who held power and were visible in New Granada, élites who raised others with a certain detachment from those already conceived from the arrival of the European world to the American world. They are intellectual, cultural and economic élites that ferment the idea that Latin America is nothing more than what history has left us, and what such history has left us, began with the arrival of Europe to America.
\end{abstract}

Keywords: intellectual elites, economic elites, political elites. 


\section{Introducción}

El presente informe de investigación tiene como fin caracterizar la genealogía de las élites y su desarrollo histórico desde la llegada de los españoles a América y su poder absoluto, hasta la divergencia entre criollos y puros, dadas sobre los finales del siglo XVIII e inicios del siglo XIX, teniendo en cuenta el fortalecimiento dentro de los contextos. Esta genealogía estará basada en cómo los llegados de Europa o los llamados conquistadores, aplicaron el concepto de poder en los diferentes espacios de la América conquistada. Es por ello que, desde una visión histórica, se busca entregar al lector una información pertinente que le esclarezca algunas de las dudas que sobre los temas abordados se han generado.

Sin duda alguna, los conceptos del presente trabajo de investigación son élite y poder, los cuales desembocarán en la realidad histórica de la Nueva Granada. La relación de estos conceptos y el análisis de las realidades concernientes a la época neogranadina son los que permiten la relación con nuestra América Latina. Sin embargo, para lograr una visión holística y fundamentada del concepto de poder en la formación de la élite en América Latina, es necesario analizar los conceptos de élite, poder y América Latina, de tal forma que el informe de la investigación está esquematizado desde el concepto de élite y los ambientes que son sinónimos de su hacer. En otras palabras, el presente informe está fundamentado en el poder, es decir, en la élite como forma de poder histórica surgida de una acción concedida por la sociedad en sus diferentes épocas, bajo los idearios que en ellas se desarrollaron.

De acuerdo con lo anterior, el presente informe de investigación se justifica en el interés por buscar y crear un espacio de referencia en el cual el tema del poder esté en relación con el de élites y políticas de configuración de poder, así que obtienen una visión diferente que permita al lector enriquecer su conocimiento y proceder a expresar su opinión bajo otros puntos de vista. 
Estos temas, tanto individualmente como asociados, son asuntos que nos competen diariamente: por una parte, el poder como término individual es visto desde la "posibilidad de que una persona o un número de personas realicen su propia voluntad en una acción comunal, incluso contra la resistencia de otros que participan en la acción” (Ferrán, 2007, p. 23). Por otra parte, el término élite, en su sentido más natural y en relación con la idea sociológica, es definido desde “quienes tenían las más altas aptitudes frente al promedio general” (Valdivieso, 2009., parr. 2). Finalmente, las políticas de configuración de poder son tan amplias en definiciones como en acciones prácticas, que plantea el ejercicio del poder en relación a un conflicto de intereses. Así, las concepciones y definiciones terminológicas de los temas a tratar, nos hacen notar la actualidad de ellos en el espacio vital en el que se mueven los países latinoamericanos y en los cuales hace énfasis el espacio académico interdisciplinario, propio de la Universidad Santo Tomás.

En América Latina la sociedad se va desarrollando en el mismo sentido que se mueve la política, y ello va acompañado de las fuerzas sociales, económicas y culturales de los diferentes países, en los cuales ciertas clases o estratos sociales son los generadores de opinión y, en tanto, de decisión. Ejemplo de ello son los cargos políticos que se ocupan en muchos países de este hemisferio, donde las raíces familiares son la base del poder y fuente de elección para estos gobernantes. Esta realidad se verá reflejada desde la época neogranadina (1719-1810), que se ve presente y analizada en el tercer capítulo del presente informe de investigación, lo cual deja entrever que la realidad que hoy tiene América Latina está basada en el mantenimiento sobre el tiempo de su propia historia. 
Los aportes significativos de este trabajo de investigación, frente a la sociedad en la que vivimos y el entorno que nos acoge, son fundamentalmente, la posibilidad de visualizar desde la argumentación ejemplificada, la realidad práctica de los elementos centrales, que son poder, élite y política. Esto implica hacer un análisis desde la historia misma de los conceptos hasta aterrizarla en lo que vive Latinoamérica, para entender la relación de los conceptos en la vivencia diaria de dicha relación entre política- élite- poder.

Ahora bien, tratándose de una propuesta de estudio y relación, es necesario identificar las fuentes bases de la teoría política que tengan un carácter histórico y propositivo, tal es el caso de La Política de Aristóteles y La República de Platón, que ilustran la idea política desde nuestros primeros pensadores en la época colonial y, que a su vez, generó una ciencia que se ha ido desarrollando con sustanciales cambios en medio de las realidades sociales de la humanidad. Por otra parte, es necesario tener en cuenta los cambios sociales relacionados con otros aspectos que tiene trascendencia en lo político, como es el caso de los elementos de influencia social, es decir, la idea de cómo los individuos desde su poder, pueden determinar y/o afectar una situación decisiva que compete a una determinada población. Em ese sentido, este informe de investigación se adentra en los ámbitos epistemológicos que justifican el poder en la edad antigua y que le dan fundamento a la ciencia política en América Latina, con la idea puntual de que, al conectar las dos realidades, sea la ciencia misma la que dé las razones de la existencia de dicha conexión.

Teniendo en cuenta lo anterior, se plantea el problema para el presente informe de la investigación, como problema que se da desde la concepción de la palabra política y su relación con el poder y las élites, para ello estos temas se relacionarán en diferentes espacios como el intelectual, el político, el económico y el cultural, los cuales confluyen en su desarrollo en la 
Nueva Granada entre los siglos XVII - XVIII. El interés del tema está dado en que se concibe como una realidad vital, partiendo de lo manifestado por uno de sus primeros promotores, Aristóteles, quien afirmaba que el hombre es un Zoon politikón, un animal político, término que utilizó en La Política. Es de entender que para Aristóteles el hombre es un animal, pero que los superamos, porque estamos relacionados con elementos políticos; en otras palabras, somos seres que tenemos un principio de relación social basada en el poder. A partir de lo anterior, se hace necesario ver cómo el hombre ha posicionado escalas sociales dominantes, todo ello bajo la normatividad de poder que da la política.

América Latina ha engendrado sus formas de gobernabilidad y orden a través de la historia bajo diversas influencias, lo que nos hace accesibles a cualquier modo de poder en sus diferentes formas. Entonces, es necesario mirar el trasfondo de esa historia que nos lleva a una realidad política basada en ciertos elementos, sobre todo aquellos que soterrados u ocultos, forman las clases sociales y las élites en América Latina. Por ello, y buscando ese trasfondo, surge el siguiente interrogante ¿Qué concepto de poder subyace en la formación de élite en América Latina en general, y en la Nueva Granada de los siglos XVII y XVIII en particular?

Con miras a obtener un resultado idóneo en el presente informe de la investigación y ser consecuente con la política de la Universidad Santo Tomás, se ha planteado como objetivo general analizar la configuración de las élites intelectuales desde la categoría del poder en Nueva Granada entre los siglos XVII y XVIII. Para lograr tal objetivo y, con el fin de concretarlo, se generan unos objetivos específicos que fungen como pasos para lograr el objetivo general del presente informe de investigación, siendo ellos, identificar la historia de la política en su relación con el poder y la élite, determinar el concepto de poder en la élite de América Latina y, 
finalmente, relacionar la historia de los conceptos poder y élite con la realidad y las vivencias de estos en la Nueva Granada entre los siglos XVII a XVIII.

En relación con lo anterior, en el proceso del presente trabajo de investigación se tendrán en cuenta dos métodos de investigación. Por una parte, el método histórico crítico, el cual permite realizar un estudio fenomenológico de los hechos del pasado y relacionarlos con el presente, entregándonos la posibilidad de encontrar las debidas explicaciones que corresponden a los intereses del trabajo. Este método permite aplicar principios epistémicos y de razón fenomenológica basados en la relación de autores antiguos y las realidades que atañen a la historia de la América hispana en la época de la emancipación, tomados como referencia, para la explicación del tránsito que ha tenido, tanto el poder como la política y la élite, dentro del contexto latinoamericano. Los aspectos fenomenológicos y epistémicos permitirán que se analicen y comprueben teóricamente los elementos expuestos en el componente del informe de investigación.

En consonancia con lo anterior, el presente informe de la investigación concierne un proceso capitular en el cual se van desglosando las temáticas que se han propuesto a lo largo de esta introducción, con ello, la distribución por capítulos se dará de la siguiente forma:

El primer capítulo considera los temas del poder como base fundamental de la estructura social y de jerarquización del individuo dentro de su ambiente social, teniendo en cuenta los aspectos culturales intelectuales y económicos. Es así, como en este capítulo se busca dar a entender que el concepto de poder se ha ido transformando desde la filosofía de manera variada con el correr de los tiempos, tomando distintos puntos de vista, que, sin embargo, convergen a la influencia del poder sobre la sociedad. De allí que es importante asumir desde esos puntos de vista, lo que significa el fenómeno del poder y relacionarlo con la realidad de la América hipana 
colonial, lo cual se hará más visible en el tercer capítulo. Para lograr lo anterior, se somete el capítulo a la teorización de los filósofos clásicos hasta los pensadores modernos, es decir desde Platón hasta Gramsci, donde se exponen los idearios tendientes a lo político lo religioso y lo social.

El segundo capítulo está relacionado directamente con la configuración de las élites, concentrándose en un prospecto de explicación en posición histórica del concepto élite. Durante el capítulo se relacionan lo cultural, lo económico, lo intelectual con el concepto de poder tratado con fundamentos similares en el primer capítulo. Así pues, el centro de discusión de élite tendrá como justificación la configuración del poder en unas clases sociales que, siendo selectas, están por encima de otras que así lo aceptan.

En este capítulo, la élite también es vista desde lo posicionalmente histórico, de allí que se esboza cómo en la antigüedad este término correspondía a las jerarquías monárquicas con carácter familiar, caso expuesto por Platón y Aristóteles, quienes lo manifiestan desde la noción de castas que no son otra cosa que generaciones condicionadas a mantener esta institución por su nombre y su historia. En la edad media, se muestra desde las jerarquías eclesiales, justificadas en su función de ser la representación de Dios en la tierra, en otras palabras, la Iglesia era el poder elitista de la divinidad. Finalmente, en la edad moderna se dieron las élites políticas, económicas, culturales e intelectuales, las cuales tienen una labor importante dentro del ejercicio de los Estados y su administración, es decir, una élite constituida en los regímenes políticos.

Para lograr lo anterior, se somete el capítulo a la teorización de los filósofos clásicos hasta los pensadores modernos, es decir desde Platón hasta Gramsci, donde se exponen los idearios tendientes a lo político lo religioso y lo social. 
Finalmente, en el tercer capítulo se relacionan las élites y sus formas de configuración de poder en la Nueva Granada, teniendo en cuenta los siglos XVII y XVIII, haciendo mayor énfasis en lo que concierne al siglo XVIII. A partir de esta temporalidad, sin dejar atrás los antecedentes dados en los demás capítulos, se busca hacer un análisis sobre cómo la América hispana colonial, a partir de la fundamentación intelectual, fue cambiando sus estructuras y concepciones de la realidad que le atañían y cómo desde una visión intelectual, la cual, al observar cómo Europa se debatía entre la guerra y la paz, tomó la vocería y teorizó nuevas formas de pensamiento y acción lo que permitió la pre-fabricación de una élite en nuestro continente, que se toma desde las bases teóricas de pensadores ibéricos como los latinoamericanos y su filosofía naciente. 


\section{Capítulo I}

\section{El concepto de poder en la filosofía política}

La filosofía política entró en la humanidad cuando el hombre cayó en cuenta de que necesitaba un orden para convivir y sobrevivir en el entorno, en otras palabras, en la medida en que el hombre sale de lo sensible y entra en lo racional. El hecho de pasar a lo racional implica necesariamente que el hombre reflexione, genere una episteme sobre el poder y el orden, que a partir de los hechos que lo rodean, fomente una organización con el fin de formar un modelo de gobernabilidad.

Si vemos la política como un elemento de orden, nos tendríamos que ir a Babilonia, donde el código Hammurabi genera el primer compendio de leyes que el hombre de la época, debe cumplir para vivir en una sociedad ya jerarquizada por los poderes, es decir, aparece la ley que viene generada de la política y con ella, aparece el poder acción.

El código Hammurabi es un compendio de leyes que parte de una jerarquización de la sociedad, en la cual existen tres grupos: los hombres libres, asilan, término que se utilizaba para referenciar a los ciudadanos que tenían libertad en todos los sentidos y que, por lo tanto, gozaban de ventajas en derechos, dado que ellos ocupaban los escaños más altos de su sociedad. Los mushkennu eran empleados con derechos y los wardu, prisioneros de guerra y deudores, quienes hewredaban su condición a generaciones posteriores, esto implicaba que sus derechos eran absolutamente restringidos y no iban más allá de lo fundamentalmente necesario, como el hecho de formar pareja (Palacios y Junco, 2002, p. 37).

Por otra parte, desde la mitología griega que estaba regida por un pensamiento religioso politeísta, indica que los dioses eran los dueños y señores del destino de los hombres y que 
además de su divinidad, eran los que generaban las leyes y las normas de convivencia entre los griegos, así, eran políticos divinos, tal y como se evidencia a continuación:

Con ella recibió el hombre la sabiduría para conservar la vida, pero no recibió la sabiduría política, porque estaba en poder de Zeus. [...] Poder y Fuerza, cumplida está por vuestra parte la misión que Zeus os encomendó y nada os retiene ya aquí. (“Tragedias”, 2001, p. $3)$.

De igual forma que acontece en obras literarias como La Ilíada (Homero, 1998), donde por medio de la literatura, se hace visible la estructura socio religiosa de una cultura en una época y, a su vez, se demuestra que las creencias y las mismas formas de vida de esa cultura dependieron de un ser sobrenatural que tenía poderes sobre los naturales, así mismo en lo político.

Con la llegada del interés por explicar el origen del mundo, caso concreto de la filosofía cosmológica o presocrática, se da inicio a las preguntas universales que incitan a distanciarnos de los dioses para entender al mundo desde otros orígenes y con ello, el postular ideas tendientes a formular un gobierno de hombres para hombres, lo que distanció al hombre del poder de Zeus y su forma de dirigir la humanidad.

\section{El concepto de poder desde la filosofía clásica}

Los pensadores antiguos que postulaban el concepto de política y con ello el de poder, se forjaron el ámbito de gnoseología y paulatinamente se separaron del marco de la mitología, como fue el caso de Platón. Para este pensador, el poder debe radicar fundamentalmente en un hombre que cuente con características sobresalientes frente a los demás; estas características que son fundamentalmente humanas, van desde lo físico hasta lo moral, por ello, para Platón, quien 
ostente el poder de gobernar un pueblo, debe ser virtuoso. Esa virtud cuenta con unas características como el buen porte físico y de carácter, que él denomina como fuerza, la sabiduría del saber ser entender y comprender, es decir, ser prudente, además debe ejercer su cargo con base en la realidad de la verdad y frente al sujeto que se aplique, en otras palabras, ser justo. Pero va más allá, al afirmar que la base de esos principios está dada en la educación, la cual forja el carácter y permite la virtud moral deseada de un gobernante.

Según Platón, la educación era superior a cualquier otro bien y para su época esta era la base de todo el poder, además, se daba a entender que cuando la educación era la fuente, la política se transformaba en un bien humano, dejando de ser un acto que generaba leyes o que dirigía ejércitos, o en el peor de los males, sostenía una religión. Así pues, la misma política vista desde el simple hecho de crear leyes era maléfica, pues "todos los llamados 'bienes' corrompen al alma y la arrancan de la filosofía: la belleza, la riqueza, la fuerza corporal, las conexiones políticas influyentes y todo lo afín a estas cosas" (Platón, 1988, p.178). De allí que la sofocracia se constituye en el sistema por el cual se encuentra un verdadero gobierno: "Que es necesario que los guardianes cuenten con la educación correcta, cualquiera que ésta sea, si han de tener al máximo lo posible para ser amables entre sí y con aquellos que estén a su cuidad" (Platón, 1988, p.289).

La educación nos hace sabios y es de sabios gobernar. Ahora bien, según el pensador griego, el don de gobernar no debe generarse en varias personas porque corren el riesgo de contradecirse y de recaer en lo que se dijo anteriormente, que el justo se torne injusto influenciado por el poder que cada uno de sus cogobernantes puedan usar.

Dado todo lo anterior, el concepto de poder en Platón y su concepción la filosofía política deja de ser una forma de dominio para convertirse en un acto de virtud donde la justicia es la 
base de tal poder y donde el elemento fuerza o azar no encuentran cabida, debido a que el gobernar es un arte y tiene, según el pensador, los mismos niveles de compromiso virtuoso que cualquier otro tipo de arte:

Pues el arte de pastor no cuida sin duda de ninguna otra cosa quede aquella con respecto a la cual está organizada, a fin de procurarle lo mejor, ya que, en cuanto a si misma, el arte del pastor ya está suficientemente provista mientras nada le falte para ser arte del pastor. Del mismo modo estoy convencido de que es forzoso estar de acuerdo en que todo gobierno, en tanto gobierno, no atiende a ninguna otra cosa que al sumo bien de aquel que es su gobernado y está a su cuidado, trátese del gobierno del Estado o de ámbitos particulares (Platón, 1988, p. 87).

Por su parte, Aristóteles asume la concepción política de Platón en el sentido de que el gobernante debe ser una persona virtuosa. A partir de esta concepción de virtud, Aristóteles trabaja sobre el individuo y no sobre una forma de poder que sea en particular a la que el individuo tenga que someterse, por ello en su texto La Política define al hombre como: “el hombre, por su naturaleza, es animal político o civil, y que el que no vive en la ciudad, esto es, errante y sin ley, o es mal hombre o es más que hombre..." (Aristóteles, 1935, p. 9). Dado esto, el hombre se define dentro del contexto de ciudad, y la ciudad en el contexto de la poli, pues para Aristóteles la ciudad es un plural de ciudadanos por encima de la individualidad, "porque la ciudad es una multitud de ciudadanos" (Aristóteles, 1935, p. 109). Para Aristóteles, la ciudad debe tener hombres con diferencias, es decir, que no todos tengan las mismas virtudes, con ello deja claro de que existen diversas formas de gobernar y por ende diversas formas de poder. Sin embargo, Aristóteles mantiene la idea de un modelo de virtud fomentado por su maestro Platón. Esta virtud aristotélica, es vista en el libro La Política y se hace latente en el 
transcurrir del texto, la cual es virtud referida a la acción. Esta acción está mejor explicada en otro texto del mismo pensador que es la Ética de Nicómaco:

La virtud es una disposición adquirida de la voluntad, consistente en un justo medio relativo a nosotros, el cual está determinado por la regulación recta y tal como lo determinaría el hombre prudente...porque el ejercicio que conforme a virtud se hace, propio es de la virtud (Aristóteles, 1985, p. 168).

Aristóteles genera un concepto de virtud a partir de la voluntad y el obrar. Esta voluntad y obra la manifiesta en la felicidad, en cómo el hombre busca ser feliz; es allí, en la Ética de Nicómaco, donde el pensador divide dos grupos de elementos que nos hacen llegar a la felicidad. Uno, las cosas internas y otro, las cosas externas; sin embargo, deja claro que en ocasiones, las externas nos hacen ver la felicidad utilitariamente. Lo particular de esta posición es que entre las externas está el poder político:

Pero es evidente que la felicidad necesita también de los bienes exteriores, como dijimos; pues es imposible o no es fácil hacer el bien cuando no se cuenta con recursos. Muchas cosas, en efecto, se hacen por medio de los amigos o de la riqueza o el poder político, como si se tratase de instrumentos; pero la carencia de algunas cosas, como la nobleza de linaje, buenos hijos y belleza, empañan la dicha (Aristóteles, 1985, p. 146).

De tal forma que para Aristóteles el poder político no es una cosa desligada de la praxis de la virtud, por el contrario, la relación poder político y virtud está en que el primero es un acto del segundo; dicho de otra forma, el poder político en buenos quehaceres es un acto de virtud, al punto que nos es útil para alcanzar la felicidad, siendo este un medio dentro de los fines del hombre. Con ello, es plausible entender la relación entre virtud y poder político en este pensador. Desde la Ética de Nicómaco, tenemos una visión más amplia de lo que significa el concepto de 
poder en Aristóteles, pero no basta con eso, pues debemos saber quién es el portador de ese concepto, de allí que surge la siguiente pregunta: ¿en quién está el poder desde la perspectiva de Aristóteles?

En la antigüedad babilónica, el poder estaba basado en un grupo social definido, casi de la misma manera acontece en Platón: la diferencia es que este filósofo insiste en el nivel de educación como forma única de poder para gobernar a los individuos. En Aristóteles se hace notable su insistencia en que la virtud es la base del gobierno o mejor, de quien corresponda gobernar, virtud que va casi siempre referida al hombre.

Aristóteles es claro en su definición del hombre, al llamarlo un animal político; afirma que es un ser social que en parte necesita de los demás para sobrevivir y que vive aun cuando esté distante de ellos, pues no lo determina como hombre el hecho de estar en sociedad, lo que lo determina como hombre es su naturaleza, dado "que el que no vive en la ciudad, esto es, errante y sin ley, o es mal hombre o es más que hombre” (Aristóteles, 1995, p. 18). La idea del hombre como ser social radica en que, para Aristóteles, el hombre siendo un animal, se diferencia de los otros por ser racional, esto quiere decir que es el único ser que conforma sociedad con unos parámetros determinados y no por simple asociación. Dichos parámetros se ven instaurados en la formación de poder político, ese poder que otras especies no tienen.

Aristóteles, además de definir al hombre como un animal político, lo posesiona como el principal constituyente de la ciudad, entendiendo la ciudad como un grupo de barrios que no se constituyen por simple asociación sino por la necesidad de la compañía: "mas la compañía que se compone de muchos barrios es la ciudad, la cual, hablando sumariamente, es para sí perfecta y bastantemente suficiente, y se juntó por fin del vivir con mayor comodidad" (Aristóteles, 1995, p.35). 
Para Aristóteles, el individuo es componente de la sociedad y la sociedad prima sobre el hombre, con ello indica que la sociedad es una necesidad del hombre por naturaleza, en otras palabras, la sociedad es el resultado de la unión de los hombres que vivían en libertad y que, dadas las falencias que esto conllevaba, decidieron unirse en mutuo acuerdo. Al mismo tiempo, afirma que el hombre forma el principal núcleo de cualquier sistema político, que es la familia, la cual no antecede a la ciudad, sino que la ciudad es anterior a ella; pero más allá de esto, la ciudad y la familia son semejantes pues su administración depende de los hombres. Siendo así, el hombre inicia su papel político y de poder en el seno de la familia entendiendo que ésta, como la ciudad, deben reconocer los espacios y las labores de cada uno de sus miembros. Estos espacios y responsabilidades están dadas con detalles, como es el caso de la edad y del género. En cuanto al género, se resalta la labor del poder del hombre en relación con la mujer:

Porque el varón ha de tener señorío sobre la mujer y los hijos como sobre personas libres, pero no con una misma manera de gobierno, pues con la, mujer ha de tener señorío civil, y sobre los hijos real. (Aristóteles, 1995, p. 117).

Se entiende como señorío la autoridad que se tiene sobre determinado elemento o persona. En este caso, el señorío civil corresponde a la idea de que los hombres, frente a las mujeres, tienen partes iguales en la construcción de la familia, sin embargo, el hombre debe fijar las normas a vivir dentro del núcleo familiar. Por otra parte, el señorío real corresponde a la autoridad total sobre los hijos y la aceptación sin mérito de duda de sus hijos sobre su padre.

Finalmente, para Aristóteles el concepto de poder está vinculado con la capacidad que los ciudadanos tienen de gobernarse a sí mismos y deben ser llevados por los hombres que sean capaces de mantener la paz en su ciudad, afirmando que no es una tarea fácil, pues se debe entender que cada individuo piensa diferente y exige diferente de acuerdo a su necesidad. 


\section{Concepto de poder en la teología medieval}

En la alta edad media surgieron nuevos visones del hombre y del mundo. Surgió el cristianismo como modo de pensamiento alternativo, pero que iba enmarcado por una fuerte influencia creacionista y desde la cual parten todas las ideas de un poder supremo. En el cristianismo, la idea de poder no era una cuestión del hombre como había acontecido en Platón y en Aristóteles, sino un poder sobrenatural. Son muchos los representantes del pensamiento cristiano mediaval, sin embargo, son dos los que sobresalen: uno apegado a Platón, San Agustín y otro a Aristóteles, Santo Tomás.

En San Agustín no se presenta de manera directa una forma de política. Sin embargo, el concepto de poder está presente. Es preciso comprender que San Agustín se inclina por una perspectiva cristiana del mundo. Cualquiera pensaría que La Ciudad de Dios es una obra relacionada con Platón o Aristóteles, y puede que sí, en el sentido de que trata la composición de la sociedad a partir de lo apologético. Como bien se sabe, el padre de la iglesia concebía dos ciudades: una la ciudad de la salvación, el cielo, y otra la ciudad de la perdición, el infierno.

La ciudad del cielo o mejor, la que nos da a conocer San Agustín, es dirigida por el poder de Dios de manera directa. Ahora bien, existe Roma, la ciudad terrenal que representaba el poder y la misericordia de Dios, sin embargo, la desobediencia del hombre y el olvido que tuvieron sobre dicha misericordia, los hizo frágiles y mundanos. El imperio perdió su don y con ello su buen espíritu, por eso propone un renacimiento del imperio, pero en lo espiritual propone "una renovación del Imperio, no histórica, sino espiritual y mística” (Roche, 2010a, p. 17-40). Esta sería la segunda Roma: "su modelo sustitutivo de origen divino de la vieja Roma pagana no es la nueva Roma imperial cristiana, sino la civetas Dei, entendida como cuerpo místico y ciudad espiritual que no es de este mundo" (Roche, 2010a, p. 29). 
Con esta concepción, también se entiende que la idea política de Agustín está condicionada por su religión y preceptos, pero más allá de eso, ubica a los hombres como los encargados de Dios para gobernar la ciudad. Así pues, el concepto de poder cambia radicalmente: el poder ya no es una situación terrenal, pasa a ser un fin en sí mismo, el cual es alcanzar la paz y la salvación. Para ello, Churquinos deja claro que no está determinando un modelo político o poder político:

En efecto, los términos precisos de esta paz no son importantes, es decir, las formas políticas no son especialmente relevantes. Lo único realmente significativo es el asegurar la posibilidad de este peregrinaje a través del establecimiento de la paz terrena (Chuaqui, 2005, p. 275).

Finalmente, y a sabiendas de que el poder político no está en los hombres, es necesario dejar claros los fines de la política en la tierra. Estos están basados en una característica divina, siendo ella, la justicia, de tal forma que los hombres que hacen parte de la ciudad de Dios, deben ser justos, en ello acoge la idea platónica y aristotélica de lo justo como virtud del hombre que gobierna, teniendo en cuenta que el poder humano no está en el mismo de Dios y menos sus leyes. Las leyes humanas participan, entonces, de la ley divina o natural, pero no son equivalentes ni están relacionadas directamente. Las leyes humanas y lo político están, como todas las cosas humanas, contaminadas por el pecado, pero, como partícipes de la divina providencia, su propósito genuino debería controlar los efectos del pecado y ser un remedio para el desorden y el conflicto inherentes a la condición pecaminosa de los seres humanos.

Más allá de lo anterior, el concepto de poder en Santo Tomás viene influenciado por Aristóteles, teniendo en cuenta que Santo Tomás le da su tono cristiano, en el sentido estricto de hacer política: el Aquínate plantea la idea a partir de la moral, pues la política tiene la labor de 
hacer un papel donde el hombre y la sociedad puedan ser felices sin atropellarse entre ellos, para lograr la satisfacción de sus necesidades, de allí que el bien común es la base del todo lo que se refiera a lo político en este autor (Larraín, 2011, p. 95).

Iniciando, Santo Tomás no plantea un modo de gobierno o forma de poder, pero sí muestra posiciones contrarias, algunas ya existentes como es el caso de la tiranía, la cual constituye el fin natural de la política que es la unión y la hermandad de los hombres. Conociendo las ideas tomasinas de negación hacia una sociedad determinada por un tirano, es pertinente entender que el poder del tirano está en contra del concepto de poder que proponía el Aquínate.

Por ello, lo manifiesta Roche, para Santo Tomás "la causa eficiente de la comunidad política estaría, en el carácter cívico del hombre. La naturalidad cívica del hombre se revela en la naturalidad del lenguaje" (2010a, p. 17-40). El sentido del lenguaje es la comunicación que se debe dar en un grupo de hombres que hace parte de una misma sociedad, en otros términos, un lenguaje que unifique criterios sociales: "El segundo principio de la filosofía política de Santo Tomás puede enunciarse así: La finalidad principal de la comunidad política es la defensa y el desarrollo de la perfección de cada persona, que la integra.” (Roche, 2010a, p. 473).

Cabe resaltar también que en Santo Tomás la ley puede verse de diferentes formas. La primera, la ley eterna que se encarnan Dios y es la que rige el todo, es decir lo racional o lo irracional:

Siendo el mundo gobernado por la providencia divina, toda la comunidad del universo está regida por la razón de Dios. Y por consiguiente la misma razón que gobierna todas las cosas tiene carácter de ley, siendo de Dios como de un soberano del universo. Y ya 
que la razón divina no concibe nada en el tiempo, sino sólo en la eternidad [...], de ahí se sigue que hemos de llamar eterna dicha ley (Dri, 1999, p. 108).

La segunda forma de ley es la ley natural. Santo Tomás deja claro que la ley eterna es la ley que cubre todo, mientras que la ley natural es la ley de los hombres y que su función básica es cumplir con la naturaleza de permitir al hombre vivir en sociedad, así pues, que es un tipo de ley limitada frente al poder que Dios tiene como creador:

El hombre participa de la razón eterna, por la cual se inclina naturalmente al debido orden de sus actos y de su fin. Y tal participación de la ley eterna en la criatura racional es lo que llamamos ley natural [...] de tal manera que, la ley natural no es otra cosa sino la participación de la ley eterna en la creatura racional (De Aquino, 1996, p.8).

De tal forma que, para Santo Tomás, el poder divino guarda en si el fundamento esencial de todas las leyes y dirige la ley natural y todos sus elementos, por ende, el poder, concepto de poder en Santo Tomás, es poder divino. Según Larraín, para el Santo, el poder político corresponde a la comunidad y este es transferible a otros miembros dado que su función es gerenciar a la sociedad humana:

Ya en el ámbito de la ciudad y los hombres manifiesta que la monarquía es un buen poder, es razonable que el mejor hombre deba gobernar a los demás. Es la monarquía o el gobierno incondicional de un hombre sabio con vistas a la virtud (Larraín, 2011, p. 99). A partir de los anteriores pensadores, es claro afirmar que la filosofía política en la edad media no fue un elemento insolado o que simplemente se dio en la época y de allí no trascendió: la idea del poder divino, como fuente de gobierno, se mantuvo y se mantiene dentro de los idearios sociales de la sociedad cristiana. 


\section{Concepto de poder desde la visión política medieval}

Cuando se habla de Maquiavelo, regularmente se habla de un poder impositivo. Se utilizan términos con tendencias peyorativas como "un gobierno maquiavélico”, pero la visión del personaje escritor de El Príncipe es la de formular una forma de poder, para lo cual es válido proponer el siguiente cuestionamiento: ¿cuál es el concepto de poder en Maquiavelo?

Maquiavelo basaba su inspiración y, por lo tanto, sus teorías, en la antigua ciudad romana, en su estructura y en su forma de gobierno. No vio la posibilidad de que un Estado fuera gobernado por varios hombres, pues entre ellos se procedía a generar conflicto, que al cabo desestabilizaría a la sociedad, por ello, proponía que el gobernante debía ser uno solo; sin embargo, no se niega a las alianzas que para él son necesarias dependiendo del contexto. Tales alianzas no están sujetas a servicios entre el Príncipe y sus aliados, por el contrario, el aliarse implica que el Príncipe, con su poder máximo, someta a sus aliados a su servicio; en otras palabras, la alianza es un medio para conseguir el fin que es el poder:

El Príncipe que adquiere una provincia cuyas costumbres y lenguaje no son los mismos que los de su Estado principal, debe hacerse también allí el jefe y protector de los Príncipes vecinos que son menos poderosos que él, e ingeniarse para debilitar a los más poderosos de ellos (Maquiavelo, 1999, p. 76).

Una frase que define a Maquiavelo es "el fin justifica los medios"; sin embargo, no es de su autoría y en ninguno de sus textos existe evidencia escrita de ella, por lo que esta frase es una interpretación de su propuesta sobre cómo llegar y cómo utilizar el poder. Más allá de esta situación, el concepto de poder político en Maquiavelo se justifica en varias formas en las que el Príncipe es la autoridad absoluta sobre todos los súbditos.

El primer elemento de este concepto es que el poder puede ser hereditario: 
Digo, pues, que en los Estados hereditarios que están acostumbrados a ver reinar la familia de su Príncipe, hay menos dificultad para conservarlos, que cuando ellos son nuevos. El Príncipe entonces no tiene necesidad más que de no traspasar el orden seguido por sus mayores, y de contemporizar con los acaecimientos, después de lo cual le basta una ordinaria industria para conservarse siempre (Maquiavelo, 1999, p. 82).

En este sentido, el puede ser, implica que no necesariamente debe ser así, sin embargo, con ello demuestra que existe una buena posibilidad de gobernar sin mayores dificultades, pues es simplemente asimilar el orden de sus antepasados para determinar las leyes que a su pueblo le convienen, además de que se entiende que la humanidad es un sujeto de costumbre y siendo así, lo aceptarán como parte de esta costumbre.

El segundo elemento son los principados mixtos que son mostrados como una forma de ejercer el poder; no obstante, Maquiavelo demuestra en su texto que no son los más recomendables a menos que sean un medio para obtener el poder definitivo. Se conoce como principado mixto al nombramiento de un cierto superior, en una tierra recién conquistada que, por sus diferencias culturales o sociales, no se puede anexar rápidamente al reino conquistador; el Príncipe mixto tiene la labor de acoplar las normas, hasta que su pueblo se someta a las normas de los conquistados; sin embargo, se corren los riesgos de que aquel Príncipe mixto se intente independizar y genera inestabilidad en el reino. En este caso, se está hablando de un poder compartido, pero sujeto a las leyes del Príncipe conquistador.

En un tercer momento, el poder de la Iglesia que de alguna manera es alabado, pues Maquiavelo insiste que es una estructura fuerte e histórica donde la institución eclesiástica crea una norma tan definida que los súbditos se van a sentir conformes y el Príncipe no corre el riesgo de traición, ni de amotinamiento: 
No hay necesidad de uno ni otro para conservarlos; se sostiene uno en ellos por medio de instituciones, que fundadas antiguamente, son tan poderosas y tienen tales propiedades, que ellas conservan al Príncipe en su Estado de cualquier modo que él proceda y se conduzca (Maquiavelo, 1999, p. 116).

Por otra parte, se habla de la sociedad civil y su forma de gobernarse, entendiendo que Maquiavelo propone un principado civil. Este principado, según Maquiavelo, está condicionado a sus fuerzas electoras, que pueden ser dos. La primera, la sociedad civil, es decir, el pueblo común: si ellos lo eligen, la labor del Príncipe es defenderlos de los atropellos de quienes tienen el poder económico [una forma de expresar que tienen un poder por encima del común de las gentes]; en este caso, el Príncipe está sujeto a la desobediencia de sus súbditos, si estos se ven indefensos. Por otra parte, está el Príncipe que fue elegido por los poderosos o clases altas, en este caso, el Príncipe está sujeto a ellos y a su querer, su función es defenderles sus recursos y seguir sometiendo al pueblo a sus quereres. Aquí el Príncipe no tiene el poder, sino que es un útil del poder de la clase alta. Este modo de principado es, de alguna manera, un modelo ineficiente y que perjudica el concepto de poder que Maquiavelo quiere instaurar:

El que consigue la soberanía con el auxilio de los grandes se mantiene con más dificultad que el que la consigue con el del pueblo; porque siendo Príncipe, se halla cercado de muchas gentes que se tienen por iguales con él, y no puede mandarlas ni manejarlas a su discreción... Pero el que llega a la soberanía con el favor popular se halla sólo en su exaltación; y entre cuantos le rodean, no hay ninguno, o más que poquísimos a lo menos, que no estén prontos a obedecerle (Maquiavelo, 1999, p. 119).

En este caso, el concepto de poder se ve regido por los intereses del elector y no por el propio Príncipe que, es según Maquiavelo, a quien le compete el poder. Maquiavelo, en sus 
teorías generales, habla de los nuevos principados, los demás principados son una mención que le es útil para determinar un Príncipe real y, por tanto, un concepto de poder real. Durante la mención de los diferentes tipos de principados, lo que hace es abrir un espacio completo de las diferentes clases de principados, pero su propósito es resaltar al Príncipe nuevo, es decir, al hombre que llega al poder en un Estado, no por derechos hereditarios o de sucesión dinástica, sino por diferentes factores, que pueden ser: la propia virtud, la buena fortuna, el favor del pueblo que lo elige, la ayuda de los nobles o la colaboración militar de otros príncipes.

Para entender el concepto de poder de Maquiavelo, es necesario entender la concepción del Príncipe propuesto por él: “Todo príncipe nuevo en su soberanía nueva, se formó siempre una tropa suya" (Maquiavelo, 1999, p. 134). La primera característica es, sin duda, la fuerza militar, la cual debe ser su fuerza militar formada y armada por él, lo cual, según el mismo Maquiavelo, le da derechos naturales sobre ella. Otro elemento que define al nuevo Príncipe es su capacidad de sobreponerse a las dificultades, entendiendo que por ser nuevo y no depender de nadie, él mismo debe dar solución a sus inconvenientes y así no poner en riesgo su principado. Esto también Maquiavelo lo indica como muestra de poder: "Es incontestable que los príncipes son grandes cuando superan a las dificultades y resistencias que se les oponen” (Maquiavelo, 1999, p. 89). Sin duda, un elemento que genera respeto y poder es el de las hazañas, las cuales le dan respeto de sus súbditos, pues "ninguna cosa le granjea más estimación a un príncipe que las grandes empresas y las acciones raras y maravillosas” (Maquiavelo, 1999, p. 112).

Finalmente, el Príncipe de Maquiavelo parte del temor de sus contrarios e igualmente de sus súbditos; no es un temor fundado por el miedo dañino, sino un temor de obediencia. En este 
caso retrata lo que debe ser un Príncipe nuevo en la figura de Septimio1: "Cualquiera que examine atentamente sus acciones hallará que era, a un mismo tiempo, un león ferocísimo y una zorra muy astuta. Se vio temido y respetado de todos [...]” (Maquiavelo, 1999, p. 13). Esta definición de un Príncipe es la que le da la base a la teoría del texto, y en este caso, al contexto sobre el cual fue escrito, que como es bien sabido, fue hecho para para ser expuesta a Lorenzo II de Medici; en otras palabras, era un consejo de una forma de gobierno. consejo que tiene unos parámetros muy metafóricos, donde se basa en la naturaleza animal para exponerlos:

Maquiavelo afirma que el gobernante o Príncipe no debe ser amado, sino temido: Se presenta aquí la cuestión de saber si vale más ser temido que amado. Se responde que sería menester ser uno y otro juntamente; pero como es difícil serlo a un mismo tiempo, el partido más seguro es ser temido primero que amado, cuando se está en la necesidad de carecer de uno u otro de ambos beneficios (Maquiavelo, 1999)

Con lo anterior, es claro que el concepto de poder en Maquiavelo, no es otro que una fuerza humana distante de la bondad y la caridad y cercana al sometimiento y a la tiranía, en la que el gobernante es un absoluto señor, no solo de la verdad, sino de la humanidad y pensamiento de sus súbditos, bajo el ideal de encontrar un Estado ideal, en el cual el gobierno esté por encima de las intenciones particulares. Con ello, Maquiavelo quiebra totalmente la teoría

\footnotetext{
${ }^{1}$ Septimio Severo Emperador romano (193-211). Tras el asesinato de Pertinax, sus soldados lo proclamaron emperador en Carnuntum, y fue reconocido por el Senado a su entrada en Roma. Derrotó a sus rivales, PescennioNiger (Isos, 194) y Clodio Albino (Lugdunum [Lyon], 197). Disolvió las cohortes pretorianas y las volvió a reclutar con dacios, ilirios, tracios, sirios y africanos. Apartó a los ciudadanos romanos de los puestos en la administración y el ejército, y designó en su lugar a gente de provincias. Durante la guerra contra los partos (197-199) conquistó Babilonia y Tesifonte, la capital parta. En 198 asoció al poder a sus hijos, Caracalla y Geta. Decretó la persecución de los cristianos (202), y desde 208 combatió a las tribus montañesas de Britania. Recuperado de: http://www.biografiasyvidas.com/biografia/s/septimio.htm)
} 
de las virtudes del buen gobernante, vistas en la edad antigua con Platón y Aristóteles y en la edad media con la teología, encarnada en los padres de la Iglesia.

El concepto de poder dista de cualquier entidad democrática donde el pueblo es el beneficiado como ente social. En este caso, el concepto de poder está encaminado a lo abstracto del término Estado. Si bien es cierto, el Estado seríamos todos, también es cierto que, el Estado es regido por un poder. Dicho de otra forma, el Estado es el poder que se ejerce sobre sí mismo, sin tener en cuenta sus componentes reales que son los individuos. Al final, el poder político no es más que un servidor del poder guerrero y absolutista.

\section{Concepto de poder de los ilustrados}

"La Ilustración es la liberación del hombre de su culpable incapacidad" (Kant, 1784).

La Ilustración fue una época que no fue ajena a la política y, por ello, no pudo ser ajena al concepto de poder. Fueron varios los pensadores políticos que se aventuraron a formular nuevos visones de lo que la política debía ser y hacer. Cada uno tenía una noción aplicada desde la razón, dado que el principio de la razón surgía como la base fundamental de toda discusión en cualquier campo incluido el de la política y, a partir de ello, se puede escudriñar en el concepto de poder político en filósofos de la Ilustración.

Con el fin de encontrar el concepto de poder político en la filosofía de la Ilustración, es necesario adentrarse en sus representantes, los que generaron teorías políticas y luego, a partir de sus teorías, generar una en común que sea transversal a este concepto.

En primera instancia, Montesquieu concibe el Estado como un todo, pero en su concepción de la administración, lo ve como acción en la que debe presentarse una división 
necesaria, de tal manera que, la administración [todo], no esté sujeta a un solo individuo. El Estado repartido en poderes implica, para Montesquieu, una forma igualitaria y justa de gobernar, donde cada parte de dicha división se tendrá que responsabilizar de sus labores y de los resultados que en ellas se generen.

“Al sumar costumbres, leyes y formas de organización y de reparto de poder se conforman los diferentes sistemas socioculturales y políticos que Montesquieu resume con el concepto de espíritu general" (Martínez, 2014, p. 9).

Así pues, el concepto de poder en Montesquieu está determinado un bien compartido, lo cual no implica que dista de una cabeza superior; por el contrario, el poder debe estar sujeto a un individuo, el cual está acompañado de quienes puedan ayudar con la administración de ciertos poderes dentro el poder general. Es aquí donde surgen las llamadas ramas del poder público, dado que el "poder político comprende, por necesidad, la unión de muchas familias" (Montesquieu, 1906, p. 18).

En este sentido, es necesario saber que el término poderes se asimila en este pensador con los elementos que rigen un Estado como es el caso de quienes aplican la justica, crean las leyes y las ejecutan, para que se proceda en justicia. El concepto de poder, en Montesquieu, se encuentra encallado en el pueblo: "El pueblo que tiene el poder soberano debe hacer por sí mismo todo lo que pueda hacer bien: lo demás es preciso que lo haga por medio de sus ministros" (Montesquieu, 1906).

Dado lo anterior, sostiene Montesquieu, que la democracia es el arte de gobierno que responde a su concepto de poder, en cuanto que democracia es el gobierno del pueblo, diferenciándola de otros regímenes que podrían llegar a ser su misma función pero que no está en el mismo nivel: 
En la democracia, donde todos son iguales, y en la aristocracia, donde las leyes deben dirigir sus esfuerzos a que todos lo sean hasta el punto que la índole del gobierno lo permita, la esclavitud es contraria al espíritu de la constitución: sólo sirve para dar a los ciudadanos un poder y un lujo que no deben tener (Montesquieu, 1906, p. 351).

En su obra El Leviatán, Hobbes propone una teoría que postula de la siguiente forma: “Cómo y por qué pactos, se instituye, cuáles son los derechos y el poder justo o la autoridad justa de un soberano; y qué es lo que lo mantiene o lo aniquila" (Hobbes, 1961 p. 9). En principio, nos da una idea de lo que no es poder y que corresponde más a las ideas o idealizaciones que el hombre se hace con este término, indicando desde lo mitológico hasta nuestros días:

De esta ignorancia para distinguir los ensueños, y otras fantasías, de la visión y de las sensaciones, surgieron en su mayor parte las creencias religiosas de los gentiles, en los tiempos pasados, cuando se adoraba a sátiros, faunos, ninfas y otras ficciones por el estilo: tal es, también, ahora, el origen del concepto que la gente vulgar tiene de hadas, fantasmas y duendes, así como del poder de las brujas (Hobbes, 1961, p. 15).

Hobbes insiste en que las personas que creían en el poder mitológico sostenían una noción de castigo por parte del poder, lo cual es distante del pensamiento basado en la razón que es el que produce la ciencia, incluida la política. También, reconoce que el Estado natural no puede ser eliminado sino administrado, y que en esa administración es donde se ve el real poder político del hombre en su más pura razón: “el Estado de naturaleza es por lo tanto el escenario de igualdad y de la libertad, una libertad que cada hombre puede usar como quiera a fin de preservar su propia naturaleza" (Mattoni, 2005, p. 103). Por otro lado, se encuentra la religión, a la cual también le hace una crítica sobre el concepto de poder, que en ella se tiene. Manifiesta que el poder que la religión ofrece es un concepto basado en lo infinito y que lo infinito no está al alcance de la mente 
humana, precisamente por ser limitadas y que el concepto de Dios se torna un concepto de perfección ilimitada.

Así pues, lo que no podemos concebir, no es posible que sea verdadero, pues se sale de la ciencia y lo que se sale de la ciencia, no es fácil aplicarlo en ninguno de los campos menos, en la política. Con lo anterior, Hobbes nos demuestra que el concepto de poder debe partir de un proceso racional que solo es posible a partir de la ciencia, teniendo en cuenta que la razón es el fundamento de ella, entendiendo que la razón nos permite verlas cosas como una totalidad, “cuando un hombre razona, no hace otra cosa sino concebir una suma total” (Hobbes, 1961, p. 46). Esa totalidad y esa vista de una unidad permite al hombre entender el poder que, en términos generales, viene siendo el máximo alcance del hombre en su propia existencia:

Las pasiones que más que nada causan las diferencias de talento son, principalmente, un mayor o menor deseo de poder, de riquezas, de conocimientos y de honores, todo lo cual puede ser reducido a lo primero, es decir: al afán de poder. Porque las riquezas, el conocimiento y el honor no son sino diferentes especies de poder (Hobbes, 1961, cap. VIII, p. 18).

En este caso se refiere al poder como necesidad o afán del hombre en su interés por ser más que los otros. Plantea, también, otro poder que corresponde al poder natural y donde se puede inferir el concepto de poder político en este filósofo. En cuanto al poder natural, afirma: "El poder de un hombre (universalmente considerado) consiste en sus medios presentes para obtener algún bien manifiesto futuro. Puede ser original o instrumental.” (Hobbes, 1961, p. 32). Tales medios son las facultades del cuerpo o de la inteligencia; estas facultades son las que permiten al hombre identificarse con los demás y así formar alianzas y generar el Estado: 
El mayor de los poderes humanos es el que se integra con los poderes de varios hombres unidos por el consentimiento en una persona natural o civil; tal es el poder de un Estado; o el de un gran número de personas, cuyo ejercicio depende de las voluntades de las distintas personas particulares, como es el poder de una facción o de varias facciones coaligadas (Hobbes, 1961, p. 34).

Así pues, el poder que postula este pensador se concibe a partir de la razón. El hombre es el que tiene el poder, el cual se hace fáctico cuando, al unirse con otros, designa uno que le administre su razón, es decir, que administre el Estado. Pero al hombre que se le asigne este cargo o este poder debe ser consecuente y tener ciertas cualidades, entre las que se cuenta la reputación por sus acciones, lo cual lo hace popular y con éxito, además, debe ir acompañado de afabilidad, elocuencia, nobleza y prudencia. Estas cualidades lo hacen cercano a los hombres y respetado por todos. Lo interesante de esta visión del poder en Hobbes es que la relaciona con las creencias divinas, pues cuando un hombre cumple con dichas cualidades, está entrando en el imaginario de Dios, el cual está en la mente de los individuos a los que este hombre pretende gobernar: "Las buenas maneras son poder, porque siendo un don de Dios, recomiendan a los hombres el favor de las mujeres y extraños." (Hobbes, 1961, p. 17).

Finalmente, Hobbes deja claro que el gobernante o quien ostenta el poder debe ser un hombre sabio, y que la sabiduría se alcanza cumpliendo los preceptos presentados anteriormente, que con ellos, el que ostenta el poder dado por los otros no solamente engendra en el pueblo la confianza, sino que a sus enemigos les engendra miedo. Así pues, el concepto de poder en Hobbes es un acto de la capacidad y los dones que un hombre tiene para hacerse reconocer como representante de un Estado, entendiendo que el Estado es un cúmulo de individuos: 
Una persona de cuyos actos se constituye en auto a una gran multitud mediante pactos recíprocos de sus miembros con el fin de que esa persona pueda emplear la fuerza y medios de todos como lo juzgue conveniente para asegurar la paz y defensa común. El titular de esta persona se denomina soberano, y se dice que tiene poder soberano; cada uno de los que le rodean es súbdito suyo (Hobbes, 1961, p. 14).

Por otro lado, en la teoría de otro pensador, John Locke, el hombre está sujeto a dos formas de política, las cuales enfatizan en los derechos. Por una parte, el derecho natural, en el cual el hombre vive libre, sin condiciones, pero sin un orden establecido, es decir, sin un poder determinado que lo controle. Por otra parte, el hombre, en su naturaleza, tiene una propiedad privada: "la propiedad se entiende así ya sea en el sentido estricto de un bien objeto de la apropiación mediante el trabajo, ya sea como vida, libertad, o posiciones” (Mattoni, 2005, p. 125). Estas dos teorías parecen inofensivas, pero la primera le hace difícil el sostenimiento de la segunda: la razón es que la existencia de una libertad sin normas es causal de irrespeto del derecho del otro, por más natural que sea. De allí que surge la necesidad de un acuerdo de gobernabilidad entre los hombres.

Para lo anterior, el pensador inglés propone un modelo de gobierno en el cual el ciudadano es quien elige por convención o por pacto a unos representantes que tendrán la labor de respetar sus derechos naturales y libertades generales, creando una ley que permitan este cometido. Este pacto lo asimila a un matrimonio donde:

La sociedad conyugal se forma por pacto voluntario entre hombre y mujer, y aunque sobre todo consista en aquella comunión y derecho de cada uno al cuerpo de su consorte, necesarios para su fin principal, la procreación, con todo supone el mutuo apoyo y asistencia, e igualmente la comunidad de intereses, necesidad no sólo de su unida 
solicitud y amor, sino también de su prole común, que tiene el derecho de ser mantenida y guardada por ellos hasta que fuere capaz de proveerse por sí misma (Locke, 2012, p. 17). Sin embargo, la idea de Estado familiar es válida como Estado, no como principio de gobierno, es decir no existe un gobierno válido por herencia (Várnagy, 2000, p. 12), pues ni el mismo Adán fue colocado por Dios para tener el poder, según Locke. Todos los elementos de un Estado están sujetos a unas leyes, y todas estas leyes deben ser en común acuerdo para que el castigo de su incumplimiento sea también pactado. Enfatiza que un pueblo debe gobernarse por gente de su pueblo, aludiendo a que en ellos se concentrara el poder de manejar los derechos de sus propios conciudadanos: "En todos los gobiernos legítimos la designación de las personas que deben gobernar es tan natural y necesaria parte de la institución como la misma forma de gobierno, cuando ésta en su establecimiento viniere originariamente del pueblo" (Locke, 2012, p, 42).

Finalmente, el concepto de poder en Locke es particularmente especial en cuanto que determina la necesidad de unos gobernantes, tales gobernantes además de ser coparticipes de la generación de las leyes y de las normas, son también los encargados. También, según Locke, estos hombres deben proteger la propiedad privada que le es connatural al ser humano. Esto hace que el concepto de poder, en este pensador, esté ligado al termino de libertad; en otras palabras, el poder del individuo está ceñido en la medida que hace respetar su libertad y la de sus gobernados. Así pues, la libertad es la base fundamental de todo ser humano y la propiedad privada la demostración que esta libertad existe.

Por otro lado, Rousseau manifiesta que la libertad es un derecho natural; sin embargo, este derecho natural se ha ido perdiendo por la desobediencia de los hombres, quienes se han condenado a sí mismos y a otros a vivir esclavos. Lo anterior implica que el individuo tiene una 
libertad natural, pero la pierde porque con su llegada al mundo, ya que está sometido a una ley generada por los errores de sus mismos progenitores y demás personas.

A partir de ello, es necesario ver cómo Rousseau plantea la idea de poder, la cual no está distante de la de Locke, pues sugiere la necesidad de un gobierno que nos ayude a manejar nuestros derechos y libertades:

En una palabra, en lugar de volver nuestras fuerzas contra nosotros mismos, unámoslas en un poder supremo que nos gobierne según sabias leyes, que proteja y defienda a todos los miembros de la asociación, rechace los enemigos comunes y nos mantenga en eterna concordia (Rousseau, 1999, p. 112).

La forma en que Rousseau plantea el gobierno es, sin duda, la democracia, pues lo que la procura ante todo es la voluntad general, la cual no solamente es la base de una sociedad, sino la que determina la existencia del Estado. La democracia debe representar el poder legítimo del pueblo y por medio de él, el autor, establece las relaciones individuo - Estado, en las cuales el Estado tiene el deber de protegerlo de los enemigos que quieren desmontar la estructura establecida. Estos enemigos son la prueba de que, aun así, la democracia no es el gobierno perfecto, por cuanto no todos los ciudadanos se acogen a ella, pero es una forma de gobierno que representa a las mayorías.

De tal forma que el poder está encarnado en el pueblo y en el que escoja para ser gobernado. La idea de postular la democracia no es que Rousseau sea un demócrata, sino que en sus teorías muestran una idea tendiente a ella, pero en ningún momento la afirma como tal, puesto que "es contrario al orden natural que el gran número gobierne y que el pequeño sea gobernado" (Rousseau, 1999, p. 123). Este pensador político postula varias formas de gobierno, insistiendo que el poder debe estar en manos de quien sea capaz de gobernarlo con virtud y 
sabiduría, lo cual nos retorna a los primeros pensadores, claro está que Rousseau lo hace a su modo: "no solamente puede haber diferentes gobiernos que sean convenientes para pueblos diversos, sino para el mismo pueblo en diferentes épocas” (Rousseau, 1999, p. 100). Pero también es insistente en que el mejor gobierno es aquel que tiene la posibilidad del cambio, en la medida que este presenta fracturas. Finalmente, y casi que retornando a los antiguos, Rousseau toma una posición frente a quién debe gobernar, o mejor en quién se define el concepto de poder: “El que más sabios gobiernen la multitud es el orden mejor y más natural” (Rousseau, 1999, p. 123); y luego: "es contrario al orden natural que el gran número gobierne y que el pequeño sea gobernado" (Rousseau, 1999, p. 123).

Con los principales representantes de la Ilustración en lo que se refiere a la política, se plantea que el poder político debe ser ideado por la razón, que está sujeta a la necesidad del hombre como coparticipe del gobierno. De tal forma que el concepto de poder lleva un tránsito directo al tema del bien común, pero también, a la libertad. Para todos los pensadores ilustrados, la idea de liberarse de un esquema religioso fue fundamental. El hombre ya no debe fundar su organización en seres metafísicos, pues ellos no viven la realidad del hombre, aunque el hombre crea que de ellos depende la realidad.

Así pues, la Ilustración al dar primacía a la razón le dio primacía al poder del hombre sobre el propio hombre. Sin embargo, el concepto de poder no quedó aislado de las teorías precedentes, pues se mantuvo en casi toda la Ilustración la idea de la virtud proclamada por Platón y Aristóteles.

Finalmente, no es descabellado afirmar que para la Ilustración y para los ilustrados, por sus diversas formas de definir el poder, el concepto de poder es homólogo del ejercicio de la 
razón, pues: "La razón ilustrada es crítica en la medida en que es empírica, en la medida en que se halla ligada a la experiencia.” (Reale y Antisieri, 1995).

De esta manera llegamos a vislumbrar el problema de la configuración de poder en el pensamiento de Karl Marx en el siglo XIX. Para encontrar el concepto de poder en Marx, es necesario, adentrarnos en la lucha de clases, pues en ella encontramos una visión de lo que puede ser un poder definitivo para él: "La historia de todas las sociedades hasta nuestros días es la historia de las luchas de clases" (Marx, 2011, p. 21).

En este tono, Karl Marx es un pensador que aborda el poder a nivel del poder, poder de las clases, cómo es la clase burguesa dominante. Tal poder no es abordado en un término analítico sino en un término crítico, es decir, en el sentido de que dicho poder va por encima de las leyes naturales del Estado: en contra de este poder se encuentra el poder común, para Marx, el poder del pueblo y el que debe prevalecer: "El objetivo inmediato de los comunistas es el mismo que el de todos los demás partidos proletarios: constitución de los proletarios en clase, derrocamiento de la dominación burguesa, conquista del poder político por el proletariado.” (Marx, 2011, p. 21). Con ello queda claro cuáles son los poderes que fomentan la lucha y también hacía cuál se inclina Marx. Para entender la lucha de poderes, es pertinente clarificar qué era para Marx tal lucha y cómo se relacionan estos dos poderes, la clase burguesa y la clase obrera, para generarla.

El poder burgués es el que se basa en el dominio y la esclavitud del proletariado. Este poder se desarrolla en una sociedad que tiene el nivel monetario suficiente para apoderase del trabajo y los frutos que el proletariado dé, trabajo que está en mano de aquellos que no cuentan con el poder económico, en este caso, el poder proletario. Ahora bien, Marx en El Capital deja 
claro que los burgueses, soterradamente, hacen ver el trabajo como un acto social, dando paso a la explotación impune sobre el proletariado:

La forma de valor que reviste el producto del trabajo es la forma más abstracta y, al mismo tiempo, la más general del régimen burgués de producción, caracterizado así corno una modalidad específica de producción social y a la par, y por ello mismo, como una modalidad histórica. Por tanto, quien vea en ella la forma natural eterna de la producción social, pasará por alto necesariamente lo que hay de específico en la forma del valor y, por consiguiente, en la forma mercancía, que, al desarrollarse, conduce a la forma dinero, a la forma capital, etc. (Marx, 1987, tomo I, p. 39).

Tal naturaleza se expresa en un elemento esencial, la dialéctica del trabajo, el cual, según el pensador, es un modo de dignidad del ser humano, haciéndolo digno de ser lo que es, además en él, encuentra el poder sobre sí mismo con la demostración de sus capacidades naturales: "El trabajo es, en primer término, un proceso entre la naturaleza y el hombre, proceso en que éste realiza, regula y controla mediante su propia acción su intercambio de materias con la naturaleza" (Marx, 1987, tomo I, p. 36). Ahora la burguesía convierte este valor natural del hombre en un valor monetario, haciéndole perder la dignidad natural y dejando al individuo como un objeto del mercado: "La forma de mercancía que adopta el producto del trabajo o la forma de valor que reviste la mercancía es la célula económica de la sociedad burguesa" (Marx, 1987, p. 9).

A partir del trabajo es que Marx define la mayor parte de las ideas sobre la lucha de clases, además de referenciar el trabajo como bien natural y como medio de explotación de ese bien natural. También se acerca al resultado del trabajo que llamamos producto, afirmando que la naturaleza de este es una extensión del hombre, mientras que el capital es una ganancia 
monetaria del burgués. De igual forma, lo relaciona con la plusvalía, en el cual el trabajo es un medio de mayor ganancia para el burgués y de mayor esclavitud para el proletario. Siendo así, el capital siempre será bien de los burgueses y el mal incubado como necesidad para el proletario. Con ello se dan las alienaciones, las cuales inician bajo el proceso de manipulación del poder burgués sobre los proletarios. Por una parte, la alienación religiosa es determinada como el opio del pueblo, pues se torna en un poder que saca al hombre de su mundo real, haciéndolo creer en un universo sobrenatural en el que se refugia con la esperanza de en ese reino, descansar de la vida que por castigo le toca en lo terrenal, evadiendo su realidad y, con ello, sometiéndose al poder manipulador del burgués.

Por otra parte, tenemos la alienación social, la cual indica la forma en que los proletarios se acostumbran al trato de los capitalistas y cómo los capitalistas los enajenan con su dinero. Luego tenemos la alienación económica, donde el proletario trabaja para su básico sostenimiento y supervivencia económica, mientras que le da un ganancial económico al capitalista, en otras palabras, el proletario trabaja para sostener su mendicidad y sustentar la riqueza del burgués. Con la anterior alienación, la económica, es que se determina la división de clases, sustentándola en un concepto, la propiedad privada:

La propiedad privada sobre el suelo, y, por tanto, la expropiación de la tierra de manos del productor directo - es decir, la propiedad privada de unos, que implica la no propiedad de otros sobre la tierra- constituye la base del modo capitalista de producción” (Marx, 1987, cap. XLVII, p. 17).

Otro pensador relevante en lo que se refiere al estudio del concepto de poder es Foucault. Es el pensador político más enfático en el concepto de poder, pues sus textos están basados en dicho concepto. Se puede iniciar indicando que Foucault visualiza al sujeto social con poder, 
afirmando que puede llegar a generar conocimiento más allá de sí mismo, pues su capacidad creativa y de hacer le permite llegar a ello. Así, el sujeto social es un sujeto epistémico y no solo un objeto de la hermenéutica. Por otra parte, frente al mismo sujeto, plantea la idea de que es necesario hacerle entender que una de sus herramientas de hacerse y de construirse es el discurso, dando una nueva visión al término y a la acción, al dejar la idea de que el discurso no es solo una fuente de palabras coordinadas, sino una herramienta de encuentro y desencuentro; dicho de otra manera, es una herramienta de poder para quien lo maneja frente a aquellos que se ven limitados frente a ella (Ávila-Fuentemayor, 2007).

Para Foucault, lo importante es que al analizar el concepto de poder, se determine un mecanismo, implicaciones, relaciones y los distintos modos de poder dados en la sociedad, de allí que el concepto de poder no es una situación social única, pues es necesario entenderlo como un concepto variable según las circunstancias y los modos. Al plantear el poder es este sentido, busca también alejarse de Marx, pues Foucault entiende que el concepto del poder puede ser de diferentes modos epistémicos, sin embargo, según él, no entraría en la parte económica, pues la economía es en sí misma, un abstracto y no una fuerza de poder. Lo anterior daría cabida a la idea de una anulación del concepto de poder en la lucha de clases propuesto por Marx.

Frente a las concepciones de poder dirimidas o manejadas por Voltaire, Montesquieu, Diderot, por mencionar algunos, y los cuales tenían en común una teoría cercana a la libertad y al individuo, Foucault cree que esta concepción tiene la siguiente visión:

Cuando se definen los efectos del poder recurriendo al concepto de represión se incurre en una concepción puramente jurídica del poder, se identifica al poder con una ley que dice no; se privilegia sobre todo la fuerza de la prohibición. Me parece que ésta es una 
concepción negativa, estrecha, esquelética del poder que era curiosamente algo aceptado por muchos (Foucault, 1999, p. 56).

Esta concepción crítica que hace Foucault de cómo no debe ser visto el poder jurídico, invita a que entendamos que el poder jurídico es de cada persona, que cada individuo lo tiene como propio y que siendo así, puede generar con él, negociaciones con tal de que se le administre por otros; es allí donde nace la política y de alguna manera el Estado. Así pues, el poder jurídico no es una negación sobre el individuo, sino un elemento positivo de este.

Por otra parte, la teoría de Foucault está en contra de las teorías de poder que están encaminadas a la represión, entre ellas, las de la economía, pues planteado de esa manera. el poder que provee la economía, lo único que generaría es guerra. De allí que el poder de la guerra no es el fin concreto del poder. En este mismo sentido, estudió el poder desde la visión de los operadores de dominación, donde el individuo no debe ser cuestionado sobre cómo y por qué aceptan ser sometidos, sino por el contrario, cómo es que ellos inician las relaciones de poder. En otras palabras, no se trata de saber lo que se sabe, sino de hacer un análisis sistemático cómo se forma aquello que se sabe de las relaciones de poder (Ávila-Fuentemayor, 2007, p. 45).

Para entender a Foucault en su idea sistemática de comprensión del poder, y comprendiendo que para él las relaciones de poder no son visibles dentro de la sociedad, pero están allí, ahora el punto es basarse en la historia para descubrirlas, pero para entrar en la historia planteó cuatro necesidades: la primera buscar en lo más recóndito las relaciones de poder, segunda, estar observando el Estado y las relaciones, tercera, comprender las formas de la economía en su estructura y la cuarta, ir más allá del Estado.

Por otra parte, Foucault trata el tema del individuo, que como ya se dijo antes, debe ser cuestionado por cómo se relaciona con las estructuras de poder. Según el mismo autor, de allí 
pueden surgir varios elementos: el primero, los intelectuales con tendencias de la derecha política como de izquierda política; de estos últimos atrae la atención que él manifiesta, se creían dueños de la verdad y por lo tanto del poder:

Durante mucho tiempo, el intelectual llamado <de izquierdas> tomó la palabra y vio que se le reconocía el derecho a hablar en tanto que maestro de la verdad y de la justicia. Se le escuchaba, o él pretendía que se lo escuchase como representante de lo universal. Ser intelectual era, en cierto modo, ser la conciencia de todos (Foucault, 1999, p. 312). Así pues, la guerra es otro punto o lugar donde se puede hacer una búsqueda del poder. Para hacer una arqueología del poder, vista como una necesidad y no como un mal: "el proceso, en el antiguo derecho germánica, no es más que la continuación reglada, ritualizada, de la guerra" (Foucault, 1999, p. 317-345). Esta situación no le es indiferente a la historia, permitiendo la justificación de ver la guerra como una forma de poder e incluso de progreso: "Uno de los medios más importantes para asegurar la circulación de bienes en la alta Edad Media era la guerra, la rapiña, la ocupación de la tierra, de un castillo o de una ciudad" (Foucault, 1999, p. 367). De tal forma que, la guerra es otro elemento en el cual, la relación de poder se justifica porque en ella se encontraba la excusa propia para mantener regulado un Estado.

Pero Foucault no se detiene allí, pues analizó el concepto de poder en la sexualidad y en la medicina; en el primer aspecto no la manejó desde las relaciones sociales y los esquemas de poder que en tales relaciones se dan, la sexualidad era el resultado de las castas y también una forma de represión por parte de las clases sobre las clases, “consideraba que una sociedad desalineada era una sociedad que daba libre cauce, por ejemplo, a una sexualidad de tipo burgués, a una familia de tipo burgués, a una estética de tipo burgués” (Foucault, 1999, p. 86). El segundo aspecto lo trata históricamente, suscitando la idea del poder de la medicina en la 
antiguiedad cuando era vista como hechicería, brujería y otros términos que solo la hacían ver como un mal social, para luego pasar a ser una ciencia económica, donde las relaciones de poder se generan en la necesidad de los sujetos y en el poder del sujeto que hace parte del selecto grupo:

El surgimiento de una medicina clínica fuertemente centrada en torno al examen, al diagnóstico, a la terapéutica individual, a la exaltación explícitamente moral y científica (secretamente económica) del <coloquio singular>. En resumen, la puesta en práctica progresiva de la gran medicina del siglo XIX no se puede disociar de la organización, en la misma época, de una política de salud y de la consideración de las enfermedades en tanto que problema político y económico que se plantea a las colectividades, y que éstas deben intentar resolver a través de decisiones globales (Foucault, 1999, p. 328). Foucault toma la idea del discurso, como representación del diálogo, la intención del logos, la formación de la palabra que transmite, de la seña que nos dice y del gesto que nos informa o nos advierte; en otras palabras, Foucault inserta el discurso, no como un acto meramente comunicativo y de expresión oral, sino como herramienta de relaciones sociales: Me parece que, si se quiere realizar la historia de determinados tipos de discursos, de discursos portadores de saber, no se pueden dejar de lado las relaciones de poder que existen en las sociedades en las que funcionan esos discursos (Foucault, 1999, p. 15). Para Foucault, el discurso era otro elemento de la historia y poder, así, como tal, también hacía referencia a una manera de entender la realidad con palabras, llevándolas a un campo de hechos:

Ahora bien, yo creo que el problema no está en hacer una separación entre lo que, en un discurso, pone de manifiesto la cientificidad y la verdad, y lo que pone de manifiesto otra 
cosa, sino en analizar históricamente cómo se producen los efectos de verdad en el interior de los discursos que no son en sí mismos ni verdaderos ni falsos. La segunda razón, el segundo inconveniente, es que la ideología se refiere, a mi parecer, necesariamente a algo así como a un sujeto. La tercera es que la ideología está en posición secundaria respecto a algo que debe funcionar en relación con ella como infraestructura o determinante económico, material, etc. (Foucault, 1999, p. 495). En conclusión, el discurso es un elemento contrayente, es decir, es un acto por medio del cual todos los elementos mencionados con anterioridad, se revelan hacia las afueras de la sociedad: a partir de él se pueden observar las acciones del Estado y con él, se puede notar la economía e incluso, se puede hacer el futurismo o el más allá del Estado, en otras palabras, el poder del discurso revela la sociedad y sus cosas ocultas y sin duda el poder velado por la sociedad.

Dado lo anterior y tras tatar las incógnitas visualidades de Foucault sobre el poder, se puede afirmar que el poder está inmerso en la vivencia del individuo, que el concepto de poder no está en cómo se ejerce, no en quien lo ejerce, sino como se ha ido desarrollando. Puede sonar poco filosófico y sí muy coloquial el ejemplo, pero me atrevo hacerlo para disipar un poco el ambiente hermenéutico que propone el pensador frente al poder, la cuestión es la siguiente:

Finalmente, entendiendo el proceso concierne al concepto de poder en Foucault, se puede asegurar que este concepto en este pensador no es una situación vista desde lo empírico, sino analizada desde lo hermenéutico y comprobada desde lo epistémico, por ello para él, el poder va más allá de ser una fuerza de dominio, gobierno, fuerza natural, es más, un bien que surge de las relaciones sociales y que se construye con ellas a su vez, forma los idearios y las ideologías para que reaparezca en las acciones sociales como es el caso de la política, donde después de haberse 
construido en el fondo de la realidad social, acoge a unos y a otros y los va ubicando en el lugar que ellos mismos fueron generando dentro de sus acciones. 


\section{Capitulo II}

\section{¿Qué es una élite?}

En el primer capítulo se trabajó el concepto de poder en la filosofía política. Este concepto se asumió desde el camino que forjaron las ciencias antiguas medievales y modernas referentes al tema tratado. El presente capítulo busca responder al cuestionamiento ¿qué es una élite? y asume el mismo camino del anterior. Por esta razón, tendrá un sentido más explicativo del concepto élite, para ello surge la necesidad de relacionarlo y tomarlo como referente frente a elementos como la economía, la política, lo intelectual y lo cultural, es decir, el concepto de élite será visto como parte del constructo social que impera actualmente, explicando las razones del por qué se da tal situación.

Se contará con teorías que sustentan la supremacía de las élites en los aspectos mencionados [economía, intelectualidad, cultura y política], cómo estas parecen ser autónomas y distantes de cualquier influencia externa, pero al mismo tiempo, cómo detrás de sí mismas actúa una élite que les da forma y las determina en su actuar y su ser:

Por definición, las élites son grupos pequeños. En sociedades tradicionales las conforman las posiciones más altas de las jerarquías de linajes, de poder canónico, de realeza o de poder económico, mientras que en las sociedades modernas occidentales las élites tienden a multiplicarse, conformando un complicado sistema de minorías especializadas, vinculadas entre sí y con el orden social de manera diversa (Diez, 2003, p. 76).

Al ser el término élite, en principio, tomado como un concepto, es lógico que la primera parte del capítulo, asuma este concepto desde la noción semántica, para luego abordarlo en la 
parte significativa práctica, es decir, en su historia, por ello se encontrará la parte histórica, para luego, hacer la relación mencionada.

Dado lo anterior, el camino de este capítulo es ante todo responder al cuestionamiento, ¿qué es una élite?, fundamentándose en la acción de la élite sobre los entornos y no solo en el concepto que la designa, sin perder la noción y continuidad histórica como bien lo manifiesta Alejandro Díez Hurtado:

Las élites tienen dos tipos diferentes de funciones: por un lado, proporcionan un “modelo" de lo deseable, lo adecuado, lo más logrado en el campo en el que se desempeñan; por el otro, las élites dirigen, toman decisiones y eventualmente “gobiernan” en su ámbito de influencia (Díez, 2003, p. 85).

Teniendo en cuenta el aporte de Díez Hurtado, el ideal del presente capítulo es mostrar los dos rostros de la élite; por una parte, el aporte que da sobre el concepto en el que se desarrolla y por otro, cómo influencia la toma de decisiones sobre ese mismo elemento, lo cual se verá reflejado dentro de la teoría del capítulo.

Este término "élite" tiene una particularidad, pues proviene del lenguaje de un país donde la revolución fue la base de unos cambios políticos que hoy nos atañen a todos: Francia y su revolución francesa fue una muestra sustancial de una oposición absoluta a la élite política que dominaba la época y, al mismo tiempo, el surgimiento de otras que habrían de tomar el poder para configurar lo que hoy tenemos dentro del contexto político (Richet et al., 1996, p. 56). Ahora bien, en cuanto a lo semántico y en relación con lo anterior, el término élite significa “minoría selecta o rectora y se pronuncia en francés [élite], se adaptó al español en la forma llana élite [élite]” (Diccionario Panhispánico de Dudas, 2005). Mientras que una definición menos semántica y más social de contexto, nos dice que la palabra viene del francés élite, que es 
el conjunto de los mejores en una comunidad. La palabra francesa élite se empleaba, en el siglo XVII para designar mercancías de especial calidad y después se amplió a grupos sociales de cúpula en cualquier actividad. Este es el origen del vocablo élite que, en sentido amplio, designa un grupo selecto de personas en el orden político, científico, cultural, económico o de cualquier otra rama del saber o de la actividad humana (“Élite”, 2007., párr. 1).

De esta manera, el termino élite genera cierta discriminación entre las líneas sociales que se ubican en un país; sin embargo, la palabra élite no está relativizada a la política. Por el contrario, está dada en los mismos sujetos y objetos sociales. Así pues, se puede afirmar que el término es sinónimo de calidad y que por su razón discriminatoria define las mejores calidades sobre las que no lo son. También, este término, en algunas sociedades y dado su mal manejo y comprensión, puede tener en la práctica connotaciones segregativas, por cuanto se sobreponen las realidades sociales, no solo por su naturaleza, sino también por su estado social. El mismo Darwin (2005, p. 394), en su teoría de la evolución, sostuvo que el ser más apto es el que sobrevive, esta alusión es una manera de entender que las élites no son solo elemento de división, segregación o clasificación, sino también, una forma de adaptación al entorno y dominio de él en todos los aspectos.

En América hispana, por ejemplo, el termino élite aparece cuando los criollos caen en cuenta de que son una raza especial, que no es tenida en cuenta y que, por su pasado y origen son valiosos para la corona española, aunque esto no se demuestre como tal. De tal forma que la primera gran élite de América fue la denominada raza pura: "no resulta difícil entrever que los ilustrados locales conformaron muy pronto élites secundarias para diferenciarlas de las otras, las principales” (Peralta, 2005, p. 20). Más allá de que el término esté referido a la edad moderna, es posible encontrarlo en los procesos históricos que han rodeado a la humanidad. 
Desde el pensamiento de la Edad Antigua, encontramos una propuesta política que hace referencia a lo que define el término élite, minoría selecta o rectora, iniciando por los mismos griegos, quienes, en su politeísmo, dejaban en la escala mayor a los dioses del Olimpo: "Los dioses se acuerdan de quienes los obedecen [...] Pero no pensó que los regalos de los dioses no pueden ser destruidos con facilidad por los mortales" (Homero, 1998, p. 287). La superioridad de los dioses da a entender que en ellos se encontraba en una clase diferente y con poder. Por otra parte, Platón ya en un ámbito más humano y terrenal, deja claro que cada deber tiene su poder y cada individuo su escala:

Porque no es natural que el piloto suplique a los marineros que se dejen gobernar por él ni que los sabios vayan a pedir a las puertas de los ricos, sino que miente el que dice tales gracias y la verdad es, naturalmente, que el que está enfermo, sea rico o pobre, tiene que ir a la puerta del médico, y todo el que necesita ser gobernado, a la de aquel que puede gobernarlo; no que el gobernante pida a los gobernados que se dejen gobernar si es que de cierto hay alguna utilidad en su gobierno (Platón, 1988, p. 280).

Estas ideas fueron asimiladas por la época y por los pensadores que continuaron después de Platón. En la Edad Media, el poder de un ser superior toma vigencia, este ser es Dios. A diferencia de la Antigüedad se habla de uno solo, en el cual, caben todos los atributos del de los griegos. La similitud está en el poder que a este se le da y a partir de él, surgen unas élites humanas dentro del vocablo iglesia. Esta élite tiene sus defensores, ellos son Santo Tomás y San Agustín, quienes formularon la idea de que la élite mayor estaba en Dios. Los Santos aquí mencionados, postulan la fe como elemento rector, entendiendo la fe como creer. Esto determina la necesidad de la existencia de un elemento terrenal que fomente la creencia, de allí la existencia de la Iglesia, la cual en su sentido semántico es eclesial, término griego que significa los 
llamados, hoy también la entendemos como pueblo. Así, la Iglesia somos todos los individuos (Diccionario Panhispánico de Dudas, 2005). Con ello, se configura la idea de dos elementos: los hombres y Dios (los hombres creemos por la fe y Dios es nuestro mayor juez y ley). Sin embargo, también se dio la postulación de las élites gobernantes y surgieron las teorías sobre quién debía gobernar y qué características deberían tener este o estos gobernantes, características que confluían en una base, el poder, no un poder simple sino un poder integral, pero ante todo de dominio.

La posición medieval, en su elitismo religioso que justificaban modelo educativo, encontró oposición muchos siglos después, cuando los ilustrados que surgían en América Latina cuestionario el conocimiento a partir del modelo escolástico y tomaron una posición más de la razón Kantiana: "Decidieron que era el momento de cambiar el modo de obtener el conocimiento sobre la realidad...un importante precedente a favor de estas preocupaciones de los "espíritus cultivados" se dio a través del combate que iniciaron contra el pilar del pensamiento clásico: la escolástica” (Peralta, 2005, p. 71).

El mismo intento de buscar un nuevo modelo educativo hizo que la religión, en su intención de catolizar la sociedad, tuviese un opositor en el nuevo mundo.

Surgieron dos vertientes, una de la élite familiar de gobernantes que dominaban, sobre todo, representada por Maquiavelo:

Digo, pues, que en los Estados hereditarios que están acostumbrados a ver reinar la familia de su Príncipe, hay menos dificultad para conservarlos, que cuando ellos son nuevos. El Príncipe, entonces, no tiene necesidad más que de no traspasar el orden seguido por sus mayores, y de contemporizar con los acaecimientos, después de lo cual le basta una ordinaria industria para conservarse siempre, a no ser que haya una fuerza 
extraordinaria, y llevada al exceso, que venga a privarle de su Estado. Si él le pierde, le recuperará, si lo quiere, por más poderoso y hábil que sea el usurpador que se ha apoderado de él (Maquiavelo, 1999, p. 56).

Otra vertiente, en la que el pueblo era partícipe, sin embargo, también debería existir un grado de poder en personas capacitadas para ello, lo cual no es otra cosa que la definición pura de élite. Esta corriente estaba representada por Rock, Hobbes y Rousseau, este último es quien más enfatizó en la libertad del individuo, más allá de la necesidad de un agente rector. Ahora bien, como los hombres no pueden engendrar nuevas fuerzas, sino solamente unir y dirigir las que existen, no tienen otro medio de conservación que el de formar por agregación una suma de fuerzas capaces de sobrepujar la resistencia, de ponerlas en juego con un solo fin y de hacerlas obrar unidas y de conformidad (Rousseau, 1999., p. 79).

En la modernidad, el concepto de élite es variado y se puede contextualizar con mayor eficacia aplicándose más a los contenidos reales donde se desarrolló. Así pues, la élite es entendida como la máxima entidad que rige los aspectos que la rodean. Como se vio, esta entidad va de lo religioso a lo que el ser humano en su diario acontecer puede generar, como es el caso de lo económico, lo político y lo cultural mismo. Sin embargo, se debe comprender, retomando las primeras líneas, que el término élite determina una escala, por lo tanto, no es un concepto vacío.

En América hispana colonial, el concepto de élite se da con ciertas variantes al que se venía conociendo de Europa, aquí la élite se definía a partir de la sangre pura, es decir, los españoles, de origen constituían la élite principal, mientras que la élite secundaria, estaba fundamentada en la posesión, en los bienes que habían adquirido por su relación consanguínea de los primeros españoles, a este grupo de élite menos o élite de posesión se le llamaba, los 
criollos: "una élite colonial se definía aquel sector de la sociedad poseedor de tierras, de explotaciones mineras y de grandes circuitos comerciales" (Peralta, 2005, p. 5). Con este tipo de élite, la configuración del concepto de élite antigua no solo se certifica, sino que varía entorno a un nuevo ideario naciente, en otras palabras, el nuevo mundo asimilaba el nacimiento de una nueva élite con unos nuevos parámetros, fundados en lo económico y en lo político.

\section{Tipología de las élites}

En una sociedad tan plural como la nuestra, es común encontrar que cada cosa que identifica al hombre tenga una división de acuerdo a los ambientes y ámbitos en que se desenvuelve el individuo, en este caso, dentro de las ciencias sociales encontramos la sociología ${ }^{2}$. Una ciencia que nos permite ver a la sociedad desde diferentes ángulos, en este caso aplicado a las élites, la podemos encontrar en diferentes campos propios del desarrollo humano.

Si se quisiera determinar las élites desde cada aspecto del ser humano, saldría un sin número de divisiones, pues de la misma forma que el hombre ha pasado por el mundo, se han cambiado los modelos de pensamiento y por lo tanto las nociones que se tienen de poder y la identificación de las élites que sostienen dicho poder, todo depende de la ideología de la época en que esta se desarrolle, sobre todo en América Latina.

Siendo una estructura de poder, la élite debe tener ciertos parámetros con los cuales regula el ingreso y egreso de agentes a su nivel, evitando así la noción liberal de la élite. Es así que la conservación del Estado de élite no podría generarse en una ideología liberal, por el

\footnotetext{
${ }^{2}$ Estudio sistemático del comportamiento social y de los grupos humanos. Se centra en las relaciones sociales, cómo esas relaciones influyen en el comportamiento de las personas y cómo las sociedades, la suma total de esas relaciones, evolucionan y cambian. Recuperado de: (http://assets.mheducation.es/bcv/guide/capitulo/8448146409.pdf).
} 
contrario, es una manera de poder fundamentada en las costumbres conservadoras, lo cual lo manifiesta el mismo Gramsci:

Las clases dominantes precedentes eran esencialmente conservadoras en el sentido de que no tendían a elaborar un paso orgánico de las otras clases a la suya, esto es, a ampliar su esfera de clase "técnicamente" e ideológicamente: la concepción de casta cerrada (Gramsci, 1932, p. 45).

Visto de esta manera, las élites no son un elemento que se da al azar o que se genera de acuerdo a una variable indeterminada, por el contrario, se genera bajo unos parámetros propios de un esquema técnico y con principios establecidos por su identidad. Dicho de otra forma, las élites son apéndice de una estructura ya compuesta.

\section{Élites económicas}

Cuando se habla de la economía a nivel mundial nos estamos refiriendo a un tema que cubre una ciencia social que estudia cómo los individuos o las sociedades usan o manejan los escasos recursos para satisfacer sus necesidades. Tales recursos pueden ser distribuidos entre la producción de bienes y servicios, y el consumo, ya sea presente o futuro, de diferentes personas o grupos de personas en la sociedad (Parkin, 2004, p. 356). Esta ciencia nos permite visualizar cómo la sociedad, en lo económico, se va configurando y tal configuración va generando unas escalas que, en América Latina, son más conocidas como estratos sociales. Ello genera, al parecer, una distribución natural; sin embargo, tiende a ser más una muestra de desigualdad económica y es aquí donde aparece el término élite económica, que de alguna manera designa a los grupos sociales que ostentan el poder económico y que se identifican, también, en modelos económicos como es el caso del capitalismo, donde la empresa y los empresarios sustentados con 
la bancarización, son los sujetos del poder y de ellos se desprende la microeconomía y la macroeconomía, elementos necesarios de la definición de la élite dentro de la economía, bajo la ceración de la percepción de un bien necesario. Según la Corporación Andina de Fomento: “el acceso a los servicios financieros constituye un factor decisivo para impulsar el desarrollo económico y el bienestar de la sociedad” (CAF, 2011, p. 104).

El argumento fundante de las élites económicas está detallado en la creación y adquisición de bienes. Estos se manifiestan de manera micro o macro y guardan una cierta relación con la definición de élites, en cuanto que se habla de una población selecta del lado de la economía. Las élites económicas se expanden a la cercanía de lo que se considera economicismo, que es un criterio o doctrina que concede a los factores económicos primacía sobre los de cualquier otra índole. Frente a esta teoría, se encuentran dos posiciones. Por una parte, la economía de élite que es valorada por el capital y las clases favorecidas de la élite, en términos más corrientes, por las oligarquías y bajo los preceptos teóricos de Adam Smith, quien supone que la propiedad debe favorecer el bien privado, lo cual sustenta la necesidad de un poder que solo la élite como tal puede alcanzar, teoría que es la favorable, como ya se manifestó, a la existencia de la élite.

Sin embargo, es plausible tratar el tema que se opone a la existencia de tal élite, siendo esta la teoría marxista, la cual considera que los bienes deben ser socializados y no encumbrados por un grupo especial con determinadas características [la élite]. Esta idea se opone al economicismo pues, Marx afirma que los bienes no deben ser privados, sino independientes. Un teórico más contemporáneo, Antonio Gramsci, contrario de que la economía determinaba la estructura social, sustenta su crítica en la plusvalía, la cual está tomada por la economía como la muestra de que existe una economía pura. Sin embargo, afirma que es exactamente la plusvalía 
la que hace que la tal economía pura se torne en un economicismo. Al validar este término, está materializando la economía y no dándole un sentido científico, siendo el mismo procedimiento que hizo Marx un siglo antes (Buci-Clucksmann, 1978, p. 67).

La postulación de Gramsci frente a la economía es claramente una fórmula por medio de la cual la élite terminaría teniendo otro punto de vista, es decir, no anula el hecho de la existencia de las élites económicas, pero reformula la función de estas en cuanto a la necesidad de que dichas élites entiendan que el fin no debe ser simplemente plusválico y que debe ir centrado en aspectos más sociales: “Gramsci critica toda concepción de lo económico como objeto separado, para escribir mejor la dialéctica economía/política en el capital” (Buci-Clucksmann, 1978, p. 16).

El término micro denota algo pequeño, lo cual es cierto en cuanto al objeto individual, pero es un sofisma en cuanto a la cantidad. Si observamos alrededor, percibimos una gran variedad de cosas que se pueden comprar y vender y a ello, aunamos empleos que se ofrecen y en tanto la rotación del dinero se torna cíclica y produce ganancia, tanto para el individuo como para el Estado. En otras palabras, la microeconomía se sostiene en la relación de bienes y servicios que generan una oferta: "cantidad de un bien que los vendedores quieren y pueden vender" (Casares y Tezanos, 2010, p. 190) y, una demanda "cantidad de un bien que los compradores quieren (y pueden) comprar en cada circunstancia posible" (Casares y Tezanos, 2010, p. 112). En esta dialéctica, entra el término mercado y con ello los términos productor [empresario-élite] y comprador, quien terminaría siendo la base de la élite.

De esta forma, la microeconomía se torna un nivel de las élites económicas, por cuanto expresa la base del mercado local, donde se dan unas élites a las que se les puede llamar naturales, pues la necesidad de un hombre que consume es satisfecha por otro que produce, siendo el directo intermediario el bien económico y el acto en si se le llama mercadeo, el cual 
genera un orden establecido que se justifica en la calidad: "una organización de servicio que lleve a cargo el mercadeo con base en asesores externos o estableciendo una estructura de mercado formal muy desarrollada, para lograr la excelencia se requiere de la creación de una organización que responda" (Kotler y Bloom, 1984, p. 214).

Ahora bien, ya que se habla de la oferta y la demanda, la pregunta que nos surge es ¿oferta y demanda de qué? La respuesta tácita es de bienes y servicios. Entendiendo bienes como todo aquello que se puede palpar y tomar como objeto, un televisor, una nevera, una casa, y servicios como aquellos que son más subjetivos, la señal de cable, la telefonía celular y otros. Sin embrago, todos tienen un fin común que es satisfacer a un consumidor. Así pues, encontramos que los bienes y servicios son elementos que determinan el mercado, la oferta y la demanda y que están encaminados a un mismo objetivo que se llama consumidor ${ }^{3}$. Este consumidor es el fin último, pero dentro de la cosmovisión de la élite económica es la fuente de todos los recursos, pues sin él no existiría tal élite.

No sería exagerado afirmar que en la economía los consumidores son otra élite, o al menos, son la base de todas las élites económicas, por cuanto el ser humano necesita siempre consumir o necesita producir. Así el ser humano, más allá de ser un útil, es un ser que exige la existencia de los bienes y servicios. El empresario no es un poder sobre el consumidor, sino que el consumidor fue el primer poder sobre el empresario que le ofrece sus bienes y servicios.

\footnotetext{
${ }^{3}$ La teoría de la demanda de consumo y el estudio del equilibrio del consumidor los desarrollaron especialmente los economistas neoclásicos utilizando originariamente el concepto de "utilidad". El consumo se concibe como una acción que reporta satisfacción o utilidad al que la ejecuta y por lo tanto se intenta asociar una determinada cantidad de utilidad por cada acción de consumir. (El consumo: importancia economica y factores determinantes Guillermo de la Dehesa). Recuperado de: http://www.guillermodeladehesa.com/files/el_consumo_importancia_economica_y_factores_determinant es.pdf
} 
Si partimos de la definición de élite, es posible afirmar que la microeconomía representa una formación de élite económica por las siguientes razones: la primera, se sustenta en que existe una clase dominante, o por así decirlo, un grupo de personas capacitadas para generar un recurso y con el poder sobre otros, poder-sujeto a dar para recibir, dicho de otra forma, un poder establecido en la capacidad de proveer bienes y servicios. La segunda, es que la élite se determina en relación con los consumidores, es decir, se hace necesario un agente consumidor para que exista un agente productor, lo que conlleva a que el consumidor someta su poder adquisitivo a la adquisición de sus bienes vitales y sus servicios esenciales, mientas el productor reciba lo económico en pro de generar más producto. Así pues, la élite está en quienes reciben la sustantivación de empresarios, la llamada élite empresarial, que no es otra cosa que una élite económica.

A diferencia del término micro, el término macro nos da noción de un elemento de mayor calado y no es para menos, pues cuando nos referimos a macroeconomía, nos estamos refiriendo a un fenómeno mayor dentro de los términos económicos. En este caso, ya no se habla de una economía interna sino de una economía externa. Si bien es cierto, también trata al individuo y al Estado en sí mismo, la macroeconomía expande su universo a las relaciones económicas entre los Estados, así pues:

La macroeconomía es una disciplina que se encarga de estudiar el comportamiento y el desarrollo agregado de la economía. Cuando se habla de agregado se hace referencia a la suma de un gran número de acciones individuales realizadas por personas, empresas, consumidores, productores, trabajadores, Estado, etc., las cuales componen la vida económica de un país. (“Macroeconomía, 2015, párr. 1-2). 
En la macroeconomía cuentan mucho los estándares de vida de un país para realizar una medición de la pertinencia económica de dicho Estado. Esto lo coloca en un posición favorable o desfavorable frente a los demás. En otras palabras y en relación con el tema de élite, los estándares de vida de una nación son los que determinan qué nación hace parte de la élite. El punto aquí es que, en este aspecto ya no se habla de pequeñas agrupaciones que dan vida a un tipo de élite económica [microeconomía], sino a un Estado que en su engranaje económico se da como élite. Ejemplo de ello es que a Estados Unidos se le llama el país élite de América dentro del contexto económico y ello tiene sus razones: en el mundo, en promedio un individuo puede llegar a vivir en un estado económico normal con 20 dólares diarios, mientras que en Estados Unidos el promedio es de 91 dólares diarios para una persona en la misma escala social (Parkin, 2004, p. 116), este ejemplo deja claro que el nivel de élite de un Estado está en el bienestar de sus individuos.

Es válido aclarar que, por más que suene muy actual la estructura de las élites, este tipo de formación basada en la economía, ya existía desde la llegada de los españoles, los cuales al tomar el poder sobre la raza habitante de América, lo primero de lo que se apropiaron fue de sus bienes, estos bienes no solo daban un estatus, sino que también fortalecían el poder de la corona y, por lo tanto, dejaban por debajo cualquier principio de propiedad de los habitantes primigenios: "la explotación inmisericorde de los recursos de la Nueva Granada por parte de la metrópoli” (Peralta, 2005, p. 4). Con esta particularidad, lo que parece moderno en la economía de las élites es un poco más antiguo, desde el punto de vista del latinoamericano, dicho de otra forma, las estrategias económicas han cambiado su proceder, pero no su génesis.

Frente a los anteriores datos, surgen manifestaciones que indican que, así como se gana, se gasta, lo cual no deja de ser cierto, pero también es cierto que cuanto se gasta es medido en 
calidad y ello determina los estándares de vida que una persona pueda medir y que un Estado pueda concebir. Así pues, en la macroeconomía se somete la relación económica del Estado frente a otros como pasa en la microeconomía. En este caso, terminan siendo los empresarios aquellos Estados con mayor pulso económico, dado en una estrategia de mercadeo globalizante (Kotler y Bloom, 1984, p. 210). Esto les permite adquirir bienes y servicios fuera de sus fronteras para luego convertirlos en opciones de venta donde fueron adquiridos, llegando así a un capital cíclico y sustentable.

En la macroeconomía también se tiene en cuenta el costo de que es la cantidad necesaria de dinero para comprar los bienes y servicios de una familia típica (Parkin, 2004, p. 118). En un país de la élite económica, el costo de vida es porcentualmente igual a la ganancia que se tiene [se dice porcentualmente igual, en el sentido de que el dinero alcanza para otros elementos, mientras que en un país que no es de la élite económica el costo de vida es superior a lo que se devenga como salario]. Esta situación en los países no élites, afectan no sólo al individuo, sino al mismo Estado, que tiene que recurrir a las élites, Estados con más músculo económico, para generar recursos en empréstitos para sostener las deficiencias de sí mismo, a esto se le llama servicios financieros que generan deudas externas (CAF, 2011, p. 79).

La macroeconomía es una élite determinada por la relación comercial entre países y también, un instrumento por medio del cual, las sociedades infieren su propio progreso. Es una élite dado que, en primera instancia, exalta el poder de los países con mayores recursos, poniéndolos a la cabeza del dominio económico frente a los demás, en segunda instancia, sin estos países la competencia, término propio de la economía, sería nula, pues entre mayores potencias y élites económicas, mayores beneficios de negociación, dado que la competencia requiere un instrumento de marketing (Kotler y Bloom, 1984, p. 207), que permita al comprador 
ver en su proveedor un mayor beneficio. Así pues, las élites económicas como Rusia, Estados Unidos y Alemania determinan el movimiento de los bienes y servicios dentro de sus continentes en un sentido macroeconómico.

Al inicio se evidencia que el capitalismo es uno de los elementos que definen a la élite económica, esto se fundamenta en que el capital se representa en varios elementos: el dinero, el factor humano y el factor material. Bajo estos elementos, el capital está dirigido por el dinero, el cual determina la posibilidad de apropiarse de bienes humanos y materiales.

Partiendo de los bienes anteriores, el capital infiere en la élite más directamente en aspectos como el intercambio, la acumulación, dirección de bienes y servicios, para ello se concentra en tres términos: el primero de ellos el libre comercio, que se entiende como un concepto económico, referente a la venta de productos entre países, libre de aranceles y de cualquier forma de barreras comerciales. El libre comercio supone la eliminación de barreras artificiales [reglamentos gubernamentales] al comercio entre individuos y empresas de diferentes países. Este término, en la práctica, es una manera en que las élites se fortalecen, pues las eliminaciones de barreras comerciales les permiten dar de su producción sin tener mayores costos y obteniendo mayores ganancias. Del anterior se desprenden dos términos, importación y exportación

La importación hace referencia a "los bienes y servicios introducidos a un país mediante el comercio internacional. Una parte significativa de la oferta total de mercancías proviene, en la actualidad, de las importaciones" (Sabino, 1991, p. 65). Este proceso incide en el poder de los países élites, por cuanto ellos son los que proveen los bienes y servicios que otros países importan, en este caso, de acuerdo a los productos que se importen, se generan pequeñas élites económicas basadas en dichos productos. Del otro lado, está el país importador quien genera los 
recursos capitales para abastecerse de lo que otro produce y así, colmar las necesidades de sus ciudadanos o de su propia industria.

La exportación se define como la "venta de bienes y servicios de un país al extranjero. Gracias al rápido desarrollo del comercio internacional durante las últimas décadas, una buena parte de la producción de casi todos los países del mundo se destina a las exportaciones” (Sabino, 1991, p. 86). De las exportaciones, suele pensarse que ellas son muestra de que el país exportador es una élite y no es así, ejemplo de ello tenemos países africanos que exportan metales y sus economías son débiles. La razón es fundamentalmente la siguiente: los países importadores llevan la materia prima y con ello crean bienes de consumo que los venden a un mayor valor, así los países exportadores venden ese bien más económico para comprar el resultado de este, más costoso. Sin embargo, las exportaciones hacen parte del flujo de capital y del libre comercio entre las naciones y es una demostración de cómo el capital genera bienes y servicios que benefician a las élites económicas.

Finalmente, el capital, el libre comercio, la importación, la exportación están condicionados con la élite, pues las élites económicas son las que controlan, restringen y modelan los términos en su práctica, pero ante todo en sus resultados. La élite económica es, entonces, aquella fuerza que ostenta el poder. Se entiende que una élite económica es una fuerza de producción de bienes y servicios, que se manejan de acuerdo a dos elementos: la microeconomía, encaminada a la satisfacción del sujeto interno, en otras palabras, determina las élites que manejan la economía de un país y, por otro lado, la macroeconomía que está encaminada a manejar el poder de los selectos a puntos externos. Todo ello caracteriza un mundo globalizado y donde el capital es el fuete de todo engranaje y movimiento económico. 


\section{Élites culturales}

Una de las formas de abordar el asunto de las relaciones entre crítica y élite es partir de la consideración de la crítica misma como un producto elitista. Pero esto sólo puede decirse en relación a un determinado tipo de crítica: la que se alinea en la franja de lo que, por obsoleto que se juzgue calificarla así, sigue en cierta manera reconociéndose como alta cultura (Echevarría, 2012, p. 328).

La cultura es definida por el diccionario de la Real Academia como un conjunto de conocimientos que permiten a alguien desarrollar su juicio. Otra definición indica que la cultura es un conjunto de modos de vida y costumbres, conocimientos y grado de desarrollo artístico, científico, industrial, en una época, grupo social (Diccionario Panhispánico de Dudas, 2005).

Estas definiciones dejan entrever que la cultura es, en sí misma, la demostración de la forma de vida de una sociedad y la influencia que tiene en su entorno. El hombre es, entonces, más que un ser político un ser cultural, donde va adquiriendo tales habilidades a partir de una enseñanza que debe ser escolar o natural, como dice Mills:

Adiestrar a alguien para que maneje un torno o para que lea y escriba, es en gran parte, educar su capacidad; provocar en las personas la comprensión de lo que realmente quieren de la vida, o discutir con ellas los modos de vivir estoico, cristiano y humanista, constituye principalmente una clara educación de valor (Mills, 1987, p. 179).

Cuando se habla de cultura, se origina el término de cultura popular. Con el surgir de este término, se da por hecho que existe otra cultura que supera lo popular, aquí es donde nace el termino cultura de élite: "La cultura elitista pasa a menudo por ser una manifestación de la alta 
cultura, cuando no se identifica directamente con ella" (Echevarría, 2012, p. 328). Esta situación nos permite ahondar en la definición de élite, pues una cosa es elitista y otra élite, el primer término, visto desde la cultura, es más relacionado con aquellas actividades culturales que por su costo y envergadura, son básicamente para personas de unos recursos superiores, ahora bien, es para la élite económica, el segundo término élite cultural, corresponde a la alta cultura. Sin embargo, la una depende de la otra pues el primer término elitista, el que define la sociedad que asiste o que da vida a la cultura de élite o alta cultura (Echevarría, 2012).

Teniendo ya claro este elemento de definición y enfoque surge una pregunta: ¿por qué se habla de élite cultural? Para responder, es necesario volver a "estratificar" la sociedad, es decir, crear niveles económicos o de educación. Con ello retomamos el término cultura popular, el cual se refiere básicamente los gustos artísticos y literarios, giros idiomáticos, gestos, modos de vestir, lugares de esparcimiento que son objeto de uso o elección por las clases pobres o de clase media de una sociedad, que no ocupan lugares considerados de élite dentro de la misma. Es la cultura del pueblo en su conjunto, de la masa, que no tiene connotaciones especiales de gusto exquisito o refinamiento. En este caso se considera al pueblo, en su conjunto, como mayoría, esto hace que el concepto de élite o lo que se entiende por élite, también se mantenga, pues si el pueblo en su mayoría, no en su totalidad, es masa, se está formando la inapelable idea de que existe un grupo selecto de la sociedad general que es superior. He ahí la élite cultural. En otras palabras, sería imposible una élite cultural si no hubiese una cultura popular (Batjin, 2003, p. 89). Las élites culturales son aquellas que están compuestas por tradiciones, ideas, lengua, arte, etc., compartidas por un grupo social. Son también, un bien del cual se ha generado una relación simbiótica. En esta relación, la cultura, aun siendo antecedente de la política, se ha emparentado con ella, como lo manifiesta Gramsci: "La conquista del poder cultural es previa a 
la del poder político y esto se logra mediante la acción concertada de los intelectuales llamados “orgánicos" infiltrados en todos los medios de comunicación, expresión y universitarios" (Gramsci, 1932, p. 34). La teoría de Gramsci es práctica por cuanto es perceptible que la cultura y el poder forman una hermandad que fundamenta a la élite y le da un ingrediente diferente a cualquier otro grupo social, simbolizado en el saber y degustar de los bienes del hombre en su creatividad. La cultura elitista está integrada por la forma de pensar, de vestirse, de apreciar la vida y las creaciones humanas o de hablar, del grupo humano compuesto por las clases altas y poderosas de una sociedad. Dado este poder por herencia en familias tradicionales, o por el dinero en aquellos que pudieron conseguirlo [por esfuerzo, herencia, suerte, o tal vez no legítimamente] y lograr escalar socialmente. Con esta definición se determina qué es una élite y se deja claro por qué la estratificación que en ellas se da.

Es necesario acercar el tema cultural, más allá de la simple acción del arte, es por eso que vale recordar que la cultura es la forma en que un pueblo se expresa en sus aspectos sociales, religiosos y mismo así políticos, esto permite afirmar que América Latina tenía en su estructura, una cultura definida que no terminó, sino que se transformó con la llegada de los españoles. De cultura general, llegó a una cultura entendida como arte y que se basaba en los intelectuales y poseedores como fuente de la denominada cultura europea: "no se puede olvidar, entonces, que el substrato de los nuevos notables estaba en la tradición y que la modernidad se sobrepuso y a veces muy artificialmente, a su matriz cultural" (Peralta, 2005, p. 21).

\section{Élites intelectuales}

En este apartado de las élites, se analizará el intelecto como fuente de una clase favorecida que se cuenta entre las ya mencionadas. Se podría afirmar que hay cinco grupos que 
reúnen algunas características para ello: los grupos de poder económico, los tecnócratas, los dirigentes, los desarrollistas y los intelectuales La pregunta que nos surge es ¿cómo entendemos la existencia de una élite intelectual? Estamos en una sociedad de conocimiento, donde los más preparados gobiernan y los menos preparados están para ser dirigidos. En este caso, la intelectualidad es directamente proporcional al poder, pues son las mentes sabias las que asesoran y guían a aquellos, por diversas circunstancias, sin ser de amplios conocimientos, ostentan el dominio en una nación. Es por ello que se plantea la existencia de una relación directa entre intelectuales y clases sociales específicas. El sector mayoritario de ellos estaría ligado a los intereses de la clase dirigente y las clases dominantes aliadas con ella. Los intelectuales actuarán como voceros de esas clases, formulando y difundiendo la ideología del estatus quo. La existencia, pues, de las élites intelectuales está relacionada con el apoyo a otras élites.

De esta manera, no es difícil entender que las élites intelectuales son individuos capacitados en el conocimiento que prevé la ciencia, así pues, las élites intelectuales son formadas por aquellas personas que mejor se han preparado en las diferentes ciencias. Ello les ha permitido convertirse en la mano derecha del Estado y de las demás élites. Un ejemplo práctico podría ser el siguiente: en la sociedad existen grandes emporios económicos cuyos propietarios son ajenos a la administración, para colmar esa necesidad está en la vía un economista que se ha preparado intelectualmente para observar analizar y actuar frente a circunstancias que puedan afectar un emporio como del que se tiene que encargar o asesorar.

Dentro del contexto de las élites queda claro que existe una élite intelectual y que tiene una función, es bueno aclarar que su existencia y su función, se ubican en un contexto y en unas ideologías. Las élites intelectuales pueden tomarse desde dos perspectivas: una aquella que apoya el capital, es decir, aquella que se une a las clases élites de la economía (como se dio en el 
ejemplo anterior), permitiendo que estas prosperen, entendiendo que su posesión del capital es altamente conservadora y por tanto desligada de los bienes comunes. En este caso, renuncian a las ideas consensuadas de la sociedad para aplicar su conocimiento en un pequeño y selecto grupo. En otras palabras, algunas de las élites intelectuales se ubican en los grupos de élites económicas para hacerlas más rentables: "Por lo tanto, y en la medida en que los intelectuales sirven directamente al poder - en una jerarquía de puestos - lo hacen, con frecuencia, renunciando a su libertad". Y para no dejar duda de ello, hoy por hoy, desde el campo de la economía política, permite vincular los tópicos y las relaciones más significativas entre los intelectuales, los tecnócratas y el escenario propio de las reformas neoliberales (Álvarez y Puello, 2005, p. 71).

Por otra parte, y en menor medida que las anteriores, encontramos las élites intelectuales históricas que se han opuesto al poder y han creado su propio bando, estas élites se les ha llamado de izquierda. Son también una minoría que, a diferencia de las anteriores, no se agrupan con otras élites, sino que buscan el aval de las masas. Podría decirse que el marxismo es un claro ejemplo de ello. Esto porque siendo un gran intelectual forjó una ideología anticapitalista, es decir una élite intelectual que se oponía a las estructuras del capital como fundamento económico, político y cultural tomando como base el factor del trabajo como elemento dignificante y la emancipación de las masas como entes de valor ${ }^{4}$.

\footnotetext{
${ }^{4}$ Marx sostiene que no se puede organizar la sociedad sobre la base de una conceptualización abstracta de los derechos naturales. El análisis de carácter abstracto debe ser reemplazado por una explicación "materialista" del orden social. Para ello, es necesario priorizar el estudio de las condiciones en las que se desarrolla el trabajo en la medida en que éste permite comprender tanto el proceso de humanización como el movimiento teleológico de la historia universal. Esto significa que la realidad del hombre y de la sociedad se manifiesta en las relaciones de producción, más precisamente en las relaciones laborales, las cuales se establecen como parte del proceso de objetivación del ser humano (Historia, poder y emancipaciónen Carlos Marx Por Walter Federico Gadea. Universidad de Huelva) proceso de objetivación del ser humano.
} 
En otras palabras, la élite intelectual es una forma diferente de ver el mundo, donde los conocimientos no fueron adquiridos para el servicio de otras élites [por el contrario, están opuestas a ellas], bajo los principios del sujeto sobre el objeto, donde ya no hay una relación social, sino una relación encaminada a la producción de la mercancía y del capital.

Según el mismo Marx, estas élites ponen al hombre una escala abajo y por lo tanto los medios de producción son parte de la élite y el hombre está condicionado a ellos. Esto no debería ser así, pues con ello se están negando los derechos humanos fundamentales, en el sentido en que el sujeto libre y autónomo, creador del mundo social, se subordina a la hegemonía de la mercancía y del interés privado. De acuerdo a ello, para el marxismo, el hombre debe estar por encima de lo que produce y, por lo tanto, el hombre vendría siendo la élite sobre lo que produce y no lo que produce la élite sobre él mismo (Marx, 1987; Marx y Engels, 2011, p. 21).

Ahora bien, los intelectuales no están sujetos solamente a las élites, pues es necesario dejar claro que el ámbito intelectual es el que da origen, por ende, si bien es cierto que sustentan las élites, también en parte sustentan las que se oponen a ellas, un ejemplo de ellos es que, cuando se habla de élites intelectuales, se está hablando de las élites del capital y frente al capital también existen opositores. Tales opositores también forman una élite intelectual; por ejemplo, Engels y el mismo Marx que innegablemente hacen parte de las características intelectuales. Ellos, desde la teoría marxista, se oponen a las élites corrientes, que durante casi todo el capítulo se han trabajado, generando incluso una clara división de las élites: "la lucha política en la fábrica porque la adhesión de los intelectuales urbanos se opera gracias a la mediación política de los intelectuales orgánicos del proletariado" (Buci-Clucksmann, 1978, p. 18).

Gramsci postula dos elementos: el primero la intelectualidad urbana, vista como aquellos que se manejan en la élite capital, y un segundo al que llama la intelectualidad orgánica, que son 
los opositores de la primera. En determinados momentos se unen para formar la élite del proletariado o que defiende al pueblo de la explotación de la élite más encumbrada:

Si las relaciones entre los intelectuales y pueblo-nación, entre dirigentes y dirigidos -entre gobernantes y gobernados, son dadas por una adhesión orgánica en la cual el sentimientopasión deviene comprensión y, por lo tanto, saber (no de forma mecánica sino de manera viviente), sólo entonces la relación es de representación y se produce intercambio de elementos individuales entre gobernantes y gobernados, entre dirigentes y dirigidos; solo entonces se realiza la vida de conjunto, la única que es fuerza social. Se crea un bloque histórico (Gramsci, 1971, p. 9).

Tomando las élites intelectuales como entidades que aportan a otras élites, políticas, económicas, e incluso culturales, y que forman también una doble vía, en el sentido de apoyar y generar ideas opositoras a las élites comunes, podemos decir que son tan esenciales y justifican su existencia en el mismo sentido que construyen un Estado o mejor, lo modelan al proceder y actualización de sus conocimientos:

El concepto de la nación como crisol glorioso de razas y naciones, sustentado por las clases medias y por los intelectuales, llegó a prevalecer sobre el anglo-sionismo de quienes se interesan por la ascendencia "racial” y los árboles genealógicos, por la sociedad "con genealogía (Mills, 1987, p. 293).

Este intelectualismo llegó a América de manera diversa. Por una parte, los letrados que tenían los españoles y que coadyuvan a la administración legal de la corona dentro del territorio del nuevo mundo, por otro lado, los nuevos ilustrados que surgían en desatención a los originarios de España, es decir, los criollos ilustrados, los cuales intentaron, por medio de teorías y apoyos bibliográficos, generar unas nuevas ideas políticas que les ayudaran a mejorar su 
estatus y, por ende, su nivel de igualdad con los españoles de sangre pura. Las dos vías posibles dieron apertura a cambios positivos dentro de las élites intelectuales, las cuales ya no se aferraban a un elemento en particular, sino a dos variables, lo cual hizo que la élite intelectual fuese más abierta, pero no menos de lo que ya era:

Nuevas estrategias de promoción social, atractivas iniciativas en el campo intelectual, una política clara y relativamente consiente para implementarlas y novedosos métodos de circulación de contenidos explican el hecho de que la vivencia ilustrada hubiera logrado tal desarrollo en tan poco tiempo, tal cohesión alrededor de unos postulados afines a una expansión geográfica tan significativa por los confines de la Nueva Granada (Peralta, 2005, p. 17).

Esta situación demuestra que la élite intelectual no fue un elemento histórico que permaneció intacto desde sus orígenes, sino que fue cambiando en la medida en que las sociedades fueron viendo tal necesidad.

Finalmente, las élites intelectuales son variadas y no están enfocadas en un mismo poder como podría acontecer con las anteriores, sino que precisamente, por sus formas de desarrollarse, se tornan divergentes, pues no dependen de un único elemento rector, sino de una variabilidad de pensamientos y conocimientos sociales que se adecúan al individuo que hace parte de una de las dos élites. Así es que las élites intelectuales determinan la relación entre el poder y las clases y entre el pueblo y sus opuestos.

\section{La élite política y su estructura}

En el capítulo anterior se trabajó el término política en relación al poder. En este capítulo se han venido analizando la relación de la élite con diferentes entes humanos, la cultura, lo 
intelectual, lo económico. Ahora se asumirá la relación de la élite con lo que se podría considerar la base y referente de las anteriores, la política.

Si acordamos que la política es la cabeza mayor dentro de las anteriores élites, es entonces de entender que la política se analiza con referencia a la élite de manera particular, en otras palabras, la política como objeto de estudio. La búsqueda central es la estructura de la élite política, entendiendo que, para comprender la estructura de la política y la élite, es necesario recurrir a la estructura social, la cual es visible como un ente común donde se dan relaciones de diferentes tipos, económicas, sociales, culturales e intelectuales. Este ente común es la sociedad y en ella se forma una estructura llamada política, la cual está dirigida por un grupo de personas con capacidades para direccionar tal sociedad plural que actúa en común.

Pero es necesario resaltar también que siendo la política una ciencia más, no es la que cubre todo el universo de las ciencias y menos de la sociedad. Insisto que siendo una ciencia más, la política como tal, es otra parte de la sociedad, por ello, es de considerar la idea de Antonio Gramsci ${ }^{5}$ en cuanto a la posición de sociedad política y de sociedad civil. El hecho de separarlas permite visualizar y centrar el tema sobre el cual se trabajará. En otras palabras, la sociedad política ejerce el control sobre la sociedad civil.

Para buscar una cronología de la formación del concepto de élite política, es necesario regresar al pasado. Se podrían tratar innumerables autores, sin embargo, basta con señalar que el

\footnotetext{
${ }^{5}$ Es importante resaltar, que la concepción del Estado en Gramsci está conformada por esos dos conceptos mencionados (sociedad política y sociedad civil) que son un binomio en la teoría gramsciana del Estado y que constituye los conceptos socio-políticos y socio-históricos, que son diferentes y a su vez equivalentes en la plena convivencia, que a juicio de Gramsci es llamado bloque histórico (es la estructura y superestructura),

En el bloque histórico el Estado pertenece a la superestructura (ordenamiento jurídico, la ideología dominante, organizaciones religiosas, artísticas, lo que se ve en el cine, la prensa, el sentido común), mientras la estructura son las relaciones económicas de producción y el intercambio que el hombre realiza en su proceso de de vida. Distinguiéndose los dos niveles mencionados, los cuales corresponden ambos a la función hegemónica del grupo dominante sobre el resto de la sociedad.
} 
filósofo griego Aristóteles fue el primer pensador en hablar de la polis, dando a entender que somos seres políticos por naturaleza (Aristóteles, 1935, p. 231). Esta aseveración permite comprender que el hombre, como ser político, fomente la creación de estamentos que representen el concepto a los cuales se les llama regímenes o formas políticas, tales como la monarquía, la aristocracia y la democracia [entre los más trajinados en la historia de la humanidad]. Todos ellos juntos son los que van dando cuerpo a una estructura de lo que es una élite política compuesta por hombres de carne y hueso con ideas diversas, pero con intereses similares encaminados al poder:

Nos referimos a un hombre que se mueve en dos círculos y quizá entre ellos -digamos el industrial y el militar- y a otro hombre que penetra en lo militar y lo político, y a un tercero que se mueve en el círculo político, así como entre los que elaboran la opinión pública. Estos tipos intermedios corresponden mejor a nuestra imagen de la estructura de la élite del poder y de su funcionamiento, incluso entre bastidores (Mills, 1987, p. 334). En primera instancia, encontramos la monarquía, régimen basado en la idea de que el poder para el gobierno de la sociedad corresponde a una persona concreta (Schröder, 2004, p. 18), con carácter vitalicio y hereditario, por demás autoritario. Este tipo de gobierno genera varias élites dependiendo de su origen, así por ejemplo, el faraón era un tipo de monarca y hoy por hoy se habla de la élite de los faraones [seres que gobernaban a su placer y que se daban así mismos el nivel de dioses], muy propio de las monarquías. Encontramos una élite política, la élite de los monarcas, pues cumplen con la función de la política dentro de nuestras realidades: administrar.

La monarquía sentada en Europa lanzó sus tentáculos a tierras nuevas. Como se sabe, llegó a tocar las tierras africanas, luego indicó su brújula de poder hacia las tierras americanas, en 
ellas ejecutó su poder por medio de la realeza española, la cual no solo gobernó estos territorios, sino que, en vista de los cambios, los apaciguó cuando vio que las clases élites surgidas en el nuevo mundo, despuntaban en derechos y reclamaban lo que les era propio:

De esta forma, Carlos IV le recomendaba el nuevo virrey de la Nueva Granada Antonio Amar y Borbón un tratamiento prudente para controlar las cada vez más frecuentes manifestaciones de descontento que se estaban verificando en algunos estratos superiores de la sociedad (Peralta, 2005, p. 1).

Esto implica que la política monárquica tenía las mismas vicisitudes en Europa que aquí en América Latina y que su historia no fue diferente.

En el caso de la democracia, esta es vista como una forma de Estado en la que gobierna el pueblo. También es vista como una forma de Estado en la que gobiernan la mayoría. Ahora bien, este concepto o definición pareciese que da el nivel de élite al pueblo. Esto en parte cierto dentro de la ideología, pero en la práctica, la democracia es una forma de gobierno que promueve las élites puras $^{6}$, por cuanto el pueblo al ser quien elige le da el dominio a las élites intelectuales, culturales y económicas para que ejerzan el poder democrático, esto por medio de un sistema de elección, es decir, que se elija a una persona que represente el sentir del pueblo.

Sin embargo, este sistema está sujeto a muchas fallas, entre ellas, la pérdida de la esencia democrática y el poder del pueblo:

Así como no hay una forma de gobierno única y óptima, tampoco los sistemas electorales son uniformes; en parte, son un producto de la historia y responden al trasfondo cultural de la respectiva sociedad o bien fueron introducidos coactivamente tras la época colonial

\footnotetext{
${ }^{6}$ La democracia exige una organización que conduce de manera necesaria a la oligarquía (Tomado del texto: Rosendo Bolívar Meza. La teoría de las élites en Pareto, Mosca y Michels IZTAMLAPA Agua sobre IUJU).
} 
para ciertos fines. Para el análisis es irrelevante que se haya deseado la democracia, o al menos una democracia ficticia, la estabilidad o el respeto a las opiniones de la minoría; lo decisivo es que algunos sistemas electorales armonizan bien con la mentalidad del pueblo y que otros son considerados extraños y rechazados (Peralta, 2005, p. 8).

Finalmente, tenemos la aristocracia, una forma de poder de las élites. Esto quiere decir que hablar de élite y de aristocracia es redundar, pues es como una forma de Estado en la que gobierna una clase alta. El modelo aristocrático está basado en la nobleza pues esta forma política es definida como una clase social integrada por nobles. Ahora bien, la nobleza o aristocracia está erotizada dentro de sí misma, pues se cuenta con la nobleza alta que es la aristocracia en sí, para seguir con la nobleza baja que estaría compuesta por los más cercanos colaboradores de la alta aristocracia y la nobleza corporativa que correspondía a los militares, cofradías y caballeros (Fuertes, 2002, p.14).

Una de las formas en que la élite política se presenta con prevalencia es la aristocracia, ejemplo de ello el movimiento dado en la Nueva Granada, cuando se tendió una lucha entre los españoles y los que aquellos que tenían sangre española, pero había nacido en América. Estos dos frentes se consideraban a sí mismos, clases privilegiadas y con derechos sobre el territorio, los españoles pura sangre tenían ventaja dado que eran reconocidos por la corona y por lo tanto se les facilitaba asumir el poder; esta situación generó conflictos, tales, que fue necesaria la participación de España y sus fuerzas militares, junto con el nombramiento de personas que gobernaran por España, Mendinueta asumió el poder y la situación se complicó, por más que representara a España, no era una autoridad absoluta pues el gobierno de Ezpeleta ya había dejado el gobierno inestable, como lo manifiesta Juana María Marín León: 
Mendinueta recibió de Ezpeleta unas directrices que abogaban por la continuidad de una política encaminada a mantener el virreinato en buen estado y en quietud y orden, tal como él lo dejaba. A pesar de esta afirmación los años finales del mandato de Ezpeleta se caracterizaron por constantes desencuentros entre las autoridades coloniales y un beligerante cabildo municipal (Marín, 2000, p. 31).

Ya hecha esta presentación de la aristocracia, es de resaltar que esta forma política resume la élite en esta ciencia y a su vez, permite visualizar el origen de las élites políticas, esto se justifica en que la aristocracia es opuesta a otras formas de gobierno tales como la monarquía, pues el individualismo de esta es contrario al componente grupal de los mejores en la aristocracia, sin duda alguna es absolutamente opuesta a la democracia por cuanto la ciencia política de Atenas le da el poder al pueblo, y no es precisamente el pueblo, una clase elegida comparada con la aristocracia que por su origen es un modelo patriarcal:

El propósito de delinear una noción de identificación colectiva que aunara diferenciación y legitimidad se aprecia, a su vez, en que tanto la concepción de aristocracia como la de patriciado incluyen de manera singular la apelación al abolengo como piedra de toque de la distinción social: ambas nociones subrayan que no son privilegios de sangre o de origen los que definen a la aristocracia o al patriciado (Losada, 2005, p. 58).

Así pues, el origen de las élites política es un gramado de circunstancias que conllevan a la formación de una clase especial que dirige un Estado; el origen de esta fuerza política en clases no es nuevo, sino antiguo. Desde la misma noción griega de política, sobre todo lo relacionado con el politeísmo, donde los dioses no eran simples personajes que habitaban los altos tronos, sino seres que desde su posición dominaban el mundo como se muestra La Ilíada y La Odisea que son un reflejo de como la sociedad griega tenía ya una élite, no tan mortal como 
la actual, pero si en relación con el hombre: "Los mortales se atreven, ¡Ay!, siempre a culpar a los dioses porque dicen que todos sus males nosotros les damos, y son ellos que, con sus locuras, se atraen infortunios que el Destino jamás decretó (Homero, 1944, p. 307).

Con lo anterior, se configura el inicio de lo que se puede mencionar como estructura de la élite política, pues al crearse formas políticas, se dan estructuras que dan cuerpo a un elemento y con ello se presenta un gramado de entidades y elementos esenciales que le dan mayor fuerza y músculo, como es el caso del poder de la economía, de alguna manera mayor que cualquier otro, y de los poderes intelectuales, ellos tratados con anterioridad en relación con la élite. Ahora se buscará encajarlos en la élite particular como lo es la élite política, aun sabiendo que la política es "la organización oficial, jurídicamente reconocida y habilitada por las funciones de la seguridad pública que se entienden como tal” (Buci-Clucksmann, 1978, p. 209).

Las ciencias económicas son ciencias, por cuanto en su trasegar han dado teorías y argumentos que le han permitido al hombre, progresar y con ese progreso se han generado los poderes y por ende las élites, las cuales están encaminadas a fortalecer las bases de las élites políticas. Así pues, que responderé una pregunta ¿cómo la economía influencia a la élite política? Como sustento de respuesta, la siguiente citación: "La idea de una élite del poder se funda en y explica: 1) las tendencias institucionales decisivas que caracterizan la estructura de nuestra época, en particular, el ascendiente militar en una economía organizada en empresas privadas" (Mills, 1987). Me detendré en las élites políticas actuales, las cuales como sabemos, están claramente enmarcadas en la democracia. Los países democráticos en América tienen dos fuentes de financiación económica, una la pública y otra la privada.

La economía pública es aquella que se encargará de atender a todas aquellas acciones de la administración pública que están vinculadas a gastos y egresos públicos justamente, tal es el 
caso de los impuestos y de los gastos en los que incurre el gobierno de turno, pero también dentro de su tarea, deberá atender los fallos de mercado que puedan producirse tras la creación y la aplicación de la política económica de gobierno. La existencia de estas son las que justifican las tasas de impuestos y la reinversión de estos en el bien del pueblo, además, el pueblo de manera regular, sostiene a las élites en la estructura del poder político, cuando estas élites fomentan el buen uso a aquello que es público.

En este caso, el mérito de lo público como medio económico, es de alta influencia en la estructura de la élite política. Tal influencia es también manejada por formas políticas, tales como el socialismo y el comunismo, regímenes que sostienen que lo público prevalece sobre lo privado: "La clase política justifica su posición mediante "principios abstractos" o una "fórmula" que es compartida y aceptada por la masa poco educada; que refleja su carácter y funciones” (Blacha, 2005, p. 86). En este caso, las élites políticas se mantienen dominando lo que es ajeno al conocimiento y la educación. También es de entender que en el mismo socialismo y comunismo, existen élites pues son esenciales los pequeños grupos capacitados para manejar las masas: "El público presupone individuos informados, capaces de tomar decisiones y defender sus intereses" (Blacha, 2005, p. 82).

Por otra parte, encontramos la economía privada, este tipo de economía es la más cercana a las élites económicas y, por ende, a la estructura de poder de la élite política, en razón de que se benefician por sí mismos, entendiendo pues, que la economía privada es parte integral de las élites que, al final de cuentas, son aportantes permanentes de los Estados democráticos. Hoy por hoy, las democracias al verse globalizadas, venden los bienes o reparten bienes públicos y privado, aduciendo que el manejo y el orden, les permite a los gobernantes de turno, maniobrar en su administración política más que en la administración de lo público. Dicho de otra forma, lo 
público, para la política de élite es, de alguna manera, incómodo y costoso; esto valida la afirmación de Mills: "Explotaban los recursos nacionales, desencadenaban entre sí guerras económicas, formaban coaliciones, convertían en capital privado la riqueza pública y empleaban todos los procedimientos para conseguir sus fines" (Mills, 1987, p. 198), esto refiriéndose a los ricos, en otras palabras, a la élite de poder.

Es indudable que la economía privada influencia a la élite política, pero ¿cómo lo hace? La respuesta puede ilustrarse con dos grandes pasos: el primero, la preparación del factor humano para involucrarlo en la política:

Excluir a los demás permite al elevado y poderoso montar y sostener una serie de mundos privados en que se pueden discutir y se discuten diferentes cuestiones con las que preparan informalmente a sus jóvenes en el temple necesario para tomar decisiones. De este modo, combinan la decisión impersonal con sensibilidades informales y moldean la estructura de carácter con una élite (Blacha, 2005, p. 137).

Esto permite que la economía privada cuente con sus representantes y, por lo tanto, con un sustento permanente en la política y en los beneficios que esta contrae.

El segundo elemento, es más de conservación de su estatus económico disfrazado de altruismo, lo que le permite favores económicos de la élite política como es la disminución de impuestos: "En realidad, la creación de fundaciones se ha convertido muchas veces en un medio cómodo de evadir los impuestos, operando como bancos privados para los donantes" (Blacha, 2005, p. 96). Podrían darse más ejemplos, pero la influencia de lo económico no solo está dada en la toma de decisiones, sino en el manejo de la misma economía.

Ahora bien, las élites políticas están relacionadas en lo privado y lo público dentro de su aspecto económico y al no poderse eliminar una de las dos por ningún régimen y menos por el 
democrático, se acuñó el concepto de economía mixta, el cual trata de fomentar la idea de que un Estado desarrollado es aquel que mantiene hermanadas estas economías. Sin embargo, una siempre estará sobre otra pues, como ya se indicó, los Estados han dado prioridad a las propiedades privadas y, por lo tanto:

Una economía mixta presupone que una porción sustancial de su capacidad productiva total es poseída y controlada por el capital privado. Puesto que el gobierno sólo dispone de fondos provenientes de los impuestos o de posibles ganancias en industrias poseídas por el gobierno, es necesario tomar en préstamo al capital privado los fondos adicionales (Mattick, 1975, p. 216).

Finalmente, la influencia de la economía sobre las élites políticas está dada ya sea en lo privado, en lo público y en lo mixto, y se da claramente en una cosa esencial, la cual corresponde a que son las élites económicas, mayoritariamente privadas, son las que están en el poder político y a su vez, los que sostienen esas estructuras de la élite política.

Hemos visto que el intelecto es una capacidad adquirida por medio de la educación y la cultura, se les llama intelectuales a aquellas personas que están preparadas en los niveles académicos y que, por su conocimiento, son aptas para ser líderes dentro de diferentes campos entre ellos el de la política.

La clase intelectual es una estructura que se reivindica con el poder y la estructura de las élites políticas. Se afirma que la estructura de la élite política se forma con los regímenes y que está apoyada por la economía entonces y surge la pregunta ¿cuáles la influencia del poder intelectual en la estructura de la élite política? Para responder este cuestionamiento: [...] autores reivindican la complejidad inherente, primero, a la conformación de un campo político y de poder desde la economía profesional y, segundo, la formación y el 
tipo de relaciones que se han consolidado entre las élites estatales y las élites intelectuales... (Pilotín 2005; Pilotín y Neoburgo 2004).

En este caso, es bueno resaltar que desde Grecia y con Platón (Platón, 1988, p. 37), se plantea que quien dirige al pueblo debe ser una persona sabia, teniendo en cuenta que da esa sabiduría a los filósofos, y los filósofos no son otra cosa que las personas letradas, hoy los intelectuales. De tal forma que la influencia de las élites intelectuales, acogiéndonos a Platón, está dada en que los intelectuales son los que dan cuerpo a la estructura de la élite política. Así pues, tal estructura de élite política quedaría entendida así, en términos coloquiales, como una obra de arte. Los materiales estarían siendo representados por los regímenes, la mezcla y la figura inicial sería la economía y la parte de detalle y terminación final, correspondería a los intelectuales.

La élite intelectual es de alguna manera la que le da clase y abolengo a la estructura de la élite política, pero de igual forma, su desarrollo en la inteligencia corresponde a la estructura de dominio, pues el acto de saber implica el acto de conocer y estas dos unidas, forman de manera ineludible la capacidad de dominar y crear dominio sobre los que no cuentan con tales capacidades. Para reforzar la idea de la influencia del poder intelectual en la estructura de la élite política, es suficiente remitirnos a la ilustración, donde aquellos que fueron y son llamados ilustrados, determinaron las estructuras políticas que hoy vivimos y con ellas, su formación de escalas, por no afirmar que fueron los que, con sus teorías, utilizaron la política. Esos ilustrados caso Rousseau, Montesquieu, Voltaire, no fueron otra cosa que teóricos políticos intelectuales.

Hoy en día en América Latina, como en el mundo, el saber está ligado a la política, pero es un saber plural, no restringido a la política. En otras palabras, el árbol que mejor sombrada, para cualquier persona que se ha preparado intelectualmente, es sin duda, la política, pues allí se 
encuentra la posibilidad de aportar y de sobresalir, por ello no es para menos que se pueda cerrar este apartado con lo que manifiesta Mills:

Así, los comentaristas y los especializados, dentro y fuera de las universidades, se concentran en los planos intermedios y dentro del equilibrio de éstos porque están más cerca de dichos sectores, ya que pertenecen sobre todo a la clase media; porque estos sectores son los que suministran el contenido "ruidoso" de la política como hecho explícito y observado; porque esos puntos de vista están de acuerdo con el folklore del modelo oficial de funcionamiento de la democracia; y porque, aceptando como bueno dicho modelo, especialmente en sus manifestaciones patrioteras habituales, muchos intelectuales pueden satisfacer con gran facilidad sus impulsos políticos (1987, p. 271). Ahora bien, el acto del ser intelectual, implica un conocimiento y un saber y por lo tanto permea una cultura, hablando de cultura en términos de conocimiento. Es así como el poder intelectual no va solo dentro de la estructura de la élite política, sino que con él, entra el aspecto cultural, ligado a lo intelectual, no queriendo decir con eso que es culto quien es intelectual. Lo que se quiere afirmar es que existen grupos culturales, en su mayoría dirigidos por intelectuales que fomentan el uso de la cultura como medio de poder y de muestra de ello.

\section{Élites y poder}

Durante el transcurso de este capítulo, se ha ido manejando el término élite y poder desde su concepto y sus relaciones dentro de su estructura. Es de entender que durante todo el proceso de la tesis, se han manejado los conceptos de élite y poder haciendo relaciones con diferentes elementos que los justifican y los relacionan. Las teorías que sustentan los conceptos de élites y poder están encaminadas a lo político. 
Retomando de manera sucinta la concepción de los términos élites y poder en el ambiente político y sociológico, es de entender que todo confluye hacia ellos, partiendo de que las élites políticas están formadas por quienes son visibles y quienes no lo son, en otras palabras, por quienes rodean a aquellos que ostentan el poder, es decir, los no vistos son los que influencian las cabezas mayores del poder político.

De esta situación nace el concepto expandido de elitista, referido a la acción de mantener una visión de poder sobre los demás, visión que acepta la concepción de clase superior en cuanto a la cultura, lo intelectual e incluso lo deportivo, de allí que no es raro entender que existen deportes de élites, tenis, golf, vela, y se les dice de élite pues son personas que cuentan con un nivel económico superior y que sus roles sociales les permiten asimilar y practicar estos deportes. El caso de los deportes, que parece irrelevante es una clara manera de entender la relación entre las élites y el poder, pues esta referencia nos permite visualizar una sociedad que se estratifica de acuerdo a sus prácticas. De allí, que las élites y el poder no son una realidad distante de las escalas sociales. Por el contrario, la relación élite poder es una relación coloquial, habitual, vital e incluso necesaria para la existencia de cualquier esquema.

Pareto (Bolívar, 2002., p. 69) manifiesta que las élites se justifican en la necesidad de encontrar alguien que dirija y alguien que se deja dirigir. Aquel que dirige, debe temer la cualidad animal de una zorra, a la cual le atribuye una capacidad inicial de astucia. Estas personas que se acoplan a la zorra, tienen mayor habilidad dentro de las élites pues manejan con facilidad a los demás; sin embargo, también existen las élites alcanzadas por la fuerza. En este caso, el animal a metaforizar es el león, los hombres que se asimilan a este tipo de animal son parte de una élite que debe sostenerse por el poder de la fuerza y regularmente, está sujeto a ciertas revoluciones y oposiciones que se reprimen con el valor de esa misma fuerza que los 
define. Según Pareto, ninguna de las dos es más que otra pues las dos son formas tangentes de concepción que una sociedad debe tener de lo que significa el poder representado en las élites.

La pregunta sobre las élites y el poder debería plantearse de la siguiente manera: ¿es posible dar un sinónimo para definir las élites y el poder de manera práctica y en conjunto? Para intentar una respuesta, es posible tomar la idea de estructura y superestructuras propuestas desde Marx y luego trabajadas por Gramsci, así pues, la superestructura sería la política en su universal y las estructuras vendrían siendo la economía, la cultura y otras que se relacionan directamente con el Estado en su hacer político. De allí que las élites políticas se ubican tanto en la estructura como en la superestructura, lo cual es viable dado que las élites son componentes:

Por poder entendemos la capacidad o la fuerza de hacer alguna cosa. El poder es en el "nosotros" -en un individuo, un Estado, etc.- en relación con el "vosotros", sobre los que ejercemos nuestro poder. Poder equivaldría pues, a coerción (Fernández, 2011, p.11). De estas, regularmente podemos relacionar las élites y el poder a partir de la política, política vista desde formas de gobierno como la oligarquía, la aristocracia, sin embargo, es más un acercamiento práctico al concepto y no necesariamente la forma absoluta y pura de relacionar los términos. Si bien es cierto, en un aparte anterior se relacionan las élites encarnando el poder en la aristocracia, esto se hace como una manera de poner al lector alerta que las élites y el poder tienen representaciones, las cuales no necesariamente las remplazan.

Ahora bien, el concepto de élites es un concepto sociológico, es decir, que se refiere de una o de otra manera a las relaciones sociales, que están sujetas a un dominador y a un dominado, dominador que es el poder sobre el dominado. Por ello, es de importancia entender el concepto desde sus teóricos, iniciando por Gaetano Mosca, quien atiende estas relaciones 
sociales que forman élites, teniendo en cuenta las escalas, y sabiendo que en su obra recupera el pensamiento original de Saint-Simón. La sociedad y las élites son definidas como:

Un sistema de dos clases con una minoría dominante y una mayoría dirigida y donde, una vez que determinada sociedad llega a cierta etapa de desarrollo, el control político, en el más amplio sentido de la expresión -la dirección administrativa, militar, religiosa, económica y moral-, es ejercido siempre por una clase especial o por una minoría organizada (Fernández, 2011, p. 35).

Esta definición no es otra cosa que el argumento de que las sociedades funcionan en la medida en que en ellas existen clases especiales que las dirigen en todos los sentidos, en otras palabras, e insistiendo en lo manifestado con anterioridad, las élites son una necesidad que justifica el poder, por más odioso que sea el escalamiento y la formación estratificada de la sociedad.

Por otro lado, está la teoría de Wilfredo Pareto, el cual teorizó su posición a partir de una oposición a la teoría de la lucha de clases de Marx. La idea de este sociólogo es que son necesarias las élites y las clases superiores, por cuanto ellas mantienen el equilibrio social y de alguna manera se genera el poder que da orden social: "La clase gobernante es restaurada, no sólo en número sino en calidad, por familias que vienen de las clases inferiores, que le aportan energía y le proporcionan elementos originales para mantenerse en el poder” (Fernández, 2011, p.23). Sin embargo, este sociólogo no demerita el valor de las clases bajas, por el contrario, asume la idea de que la existencia de estas clases son las que permiten el devenir necesario de las élites y por tanto del poder. 
Finalmente, tenemos a Robert Michaels quien también difiere de Marx y asegura la necesidad de un grupo sobre las masas y, por tanto, no deben existir elementos entre las masas que se opongan a estos grupos:

Toda organización implica especialización y responsabilidad de los líderes, los cuales se hacen expertos en conducir a las masas. Así, la democracia termina convirtiéndose en una forma de gobierno de los mejores: en una aristocracia. Tanto en lo material como en lo moral, son los líderes quienes han de ser considerados los más capaces y los más maduros (Fernández, 2011, p.63).

Para este sociólogo, los modelos o formas de gobierno no afectan las élites o no existe la posibilidad de que una sea más élite que otra. Por el contrario, cada forma, modelo o ente político, necesariamente es un compuesto de poderes a los cuales se sujetan las masas.

Las élites y el poder son dos conceptos que implican superioridad, pero es suficiente visualizar los conceptos desde lo coloquial o lo local, donde el poder es visto como una capacidad superior e incluso sobrenatural. Sin embargo, el poder es más sencillo de entender, pues es fácilmente ubicable en lo cotidiano, la familia, el trabajo, el deporte, y en otras tantas realidades que transitamos a diario:

Los poderes de los hombres corrientes están circunscritos por los mundos cotidianos en que viven, pero aún en esos círculos del trabajo, de la familia y de la vecindad muchas veces parecen arrastrados por fuerzas que no pueden ni comprender ni gobernar (Mills, 1987, p. 77).

A lo anterior lo podemos llamar poder natural, pues no se ejecuta sobre una base de elección ajena, sino de naturaleza propia, como el poder que tienen los padres sobre sus hijos. Ahora bien, del poder natural pasamos al poder adquirido, el cual es precisamente lo contrario, 
un poder que se da por reconocimiento de otros. En otras palabras, podríamos hablar de poder político. El político asume el poder porque el pueblo le dio su aval para que asuma tal posición, con ello se cumple la teoría de Hobbes (1961., p.45), que el hombre debe entregar parte de su libertad a un gobernante para evitar que los hombres se devoren entre ellos; en este último espacio, en el poder adquirido no de manera natural es donde más se encumbra el concepto de poder.

Sea cual fuere el concepto de poder, siempre se va a tener una idea tangente de una escala, es decir, que existe la visión de un sujeto o sujetos ubicados en una élite especial y que por ello puede tomar decisiones que afecten o beneficien a quien está subordinado. Sin embargo, existen teorías que distancian el poder del sujeto, como es el caso de Foucault, quien asume una posición crítica frente a la idea de que el Estado tiene el poder; para él eso no es posible, pues hasta ahora lo único que ha existido es un gramado de teorías y no prácticas consistentes. El poder, desde el punto de vista del Estado, está limitado aun creyendo que la concepción de Estado es errada. Es mismo así todo lo que sobre él se contempla, como es el caso de las élites y el poder.

En términos distintos, el Estado es un concepto en el valor de la palabra, pero no una realidad tangente, palpable, sobre la cual se puedan ejercer creaciones como son los conceptos de élite y poder:

Descubrí que, en tanto la historia y las teorías económicas constituían un buen instrumento para el estudio de las relaciones de producción, y la lingüística y la semiótica ofrecían elementos para el estudio de las relaciones de significación, para el estudio de las relaciones de poder no poseíamos en cambio ninguna herramienta. Teníamos que recurrir exclusivamente a sistemas de pensamiento sobre el poder basados en modelos legales, o 
sea: ¿qué legitima el poder? O bien a sistemas de pensamiento sobre el poder basados en los modelos institucionales, o sea: ¿qué es el Estado? (Foucault, 1995, p. 29).

La crítica, por otra parte, también se encamina a la relación de poder con otras ciencias como la economía, pues se habla de poder económico, cual si el referente fuese el poder y la economía fuera su subordinado, siendo sistemáticos, debería hablarse de economía de poder donde el referente es la economía ya que, al surgir en ciertos círculos, le da poder a dichos elementos que se constituyen en élites. Así que, para este pensador, es necesario, antes que nada, recurrir a la historia, partiendo de un método genealógico, por medio del cual se busca el referente que explica su pasado que permita el análisis desde sus orígenes, tomando como elemento el individuo.

Finalmente, y asumiendo que para Foucault, el término poder no lo podemos asimilar desde otro concepto, como es el caso de Estado, sino desde su origen como concepto y entendiendo que este pensador utilizó como medio metodológico lo genealógico ${ }^{7}$, es necesario, igualmente, asimilar la realidad de las élites al igual que la de poder como una acción indeterminada y que es posible determinar solo por medio de la historia.

Ahora bien, no es la única teoría de poder relacionada con las élites. Existen otras como la de Max Weber. Para él, el poder no es otra cosa que la capacidad de conseguir que otra persona haga algo, aún en contra de su voluntad (Rodríguez, 2005, p. 87). En este caso, observamos la visión de poder, definida a partir de la superación de un individuo sobre otro, en otro sentido, el poder es dado gracias a una relación entre individuos, donde unos que denominamos las élites están sobre los otros en el sentido de dominio, con ello anula el

\footnotetext{
7"Llamamos genealogía al acoplamiento de los conocimientos eruditos y de las memorias locales que permite la constitución de un saber histórico de la lucha y la utilización de ese saber en las tácticas actuales" (Foucault, 1992).
} 
individualismo de los sujetos, pues este individualismo no hace posible las élites ni el poder, por el contrario, los elimina.

La teoría de Weber es complaciente con las élites pues al oponerse a Foucault, nos está diciendo que las relaciones sociales parten de los individuos y que la historia existe en la medida que existen dichas relaciones. Ahora bien, aquí no se trata de un sometimiento en contra de voluntades, como lo afirma Weber, en este caso el poder surge en lo social, pues las relaciones sociales solo se dan en la medida en que los individuos lo acuerden, obviamente hablando del punto de vista positivo, pues viéndolo desde lo negativo encontramos las dictaduras, en América Latina, Rosas, Pinochet, que fueron tomadas como acciones fuera de los acuerdos de los individuos, mientras otras que son soterradas y veladas con el concepto de democracias, casos que se dan en la mayoría de países de América Latina.

Esta forma de ver el poder, que dista de Foucault, es la más común y sin duda la que nos permite analizar el Estado desde su conjunto como elemento de poder, insistiendo que el Estado somos todos y todos somos individuos en constante relación por no decir, en relación de poder:

En la actualidad, se ha recuperado la conceptualización del poder como un fenómeno que sólo puede tener lugar en una relación. El poder mismo es una relación entre al menos dos individuos. No puede pensarse que una persona aislada tenga poder en su soledad (Rodríguez, 2005, p. 76).

La teoría de poder del pensador alemán, Niklas Luhmann, quien asume el poder como un código comunicativo que permite a quien lo maneje tener poder sobre quien está limitado, de tal forma que el poder es un acto humano permitido incluso en el mismo hecho de comunicarse "el poder funciona como un medio de comunicación, ordena las situaciones sociales con una selectividad doble" (Luhmann, 2005, p. 50). 
El pensador alemán conceptúa la selectividad doble, en cuanto al código comunicativo que determina el poder en dos sentidos. El primero es que el acto comunicativo que se ejerce en el poder, el cual puede exaltar al opuesto y el segundo o puede someterlo; es aquí donde encajan las élites intelectuales, culturales, económica y políticas, pues en los dos casos el poder es visible, porque si nos dirigimos a la vida diaria, entendemos que no todo el mundo tiene el poder de levantar el ánimo de otro haciéndolo sentir poder, como tampoco todo el mundo tiene el poder de rebajar a otro volviéndolo su esclavo.

No sobra retomar a Mills como refuerzo del presente apartado y en relación con la comunicación. En este caso en un ambiente geográfico concreto, y más destinado a los medios de información que son, en realidad, los que manejan los códigos de información cuando afirma que:

Como los medios de información y poder están centralizados, algunos individuos llegan a ocupar posiciones en la sociedad norteamericana desde las cuales pueden mirar por encima del hombro, digámoslo así, a los demás, y con sus decisiones pueden afectar poderosamente los mundos cotidianos de los hombres y las mujeres corrientes (Mills, 1987, p. 88).

Frente a lo anterior es considerable afirmar que los medios de información son una muestra fehaciente de que la comunicación es un poder manejado por las élites. Finalmente, en este capítulo, en el que se ha priorizado el concepto de las élites para luego relacionarlo con la teoría del primer capítulo, que correspondía al concepto de poder, fue necesario retomar teorías y acoplarlas con otras, a fin de llegar a entender que las élites como el poder, son conceptos que no se limitan exclusivamente a lo político. Es decir que las élites y el poder son conceptos relativos a quien tiene el mando sobre los bienes sociales, económicos, intelectuales, políticos y, cabe 
también decirlo, históricos como lo plantea Foucault. Fue necesario recurrir a teóricos y sus teorías prácticas, en un recorrido histórico que se inició desde la antigüedad: Babilonia y el código Hammurabi, Egipto y los faraones, Grecia y el politeísmo junto con sus filósofos Platón y Aristóteles y, en la edad media Santo Tomás, San Agustín y, en los albores de la edad moderna con Maquiavelo, Rousseau, Hobbes, Rock, Montesquieu, y posteriormente, con Marx, y el mismo Foucault.

Todos ellos nos permiten ver que, las élites y el poder hace tiempo dejaron de ser conceptos desprovistos de contenido, para convertirse en realidades objetivas desde las prácticas más coloquiales, hasta las más epistémicas, y cómo estas élites y la formación de ellas dieron cabida a una forma de congregarse y formar identidad en América Latina. Las élites latinoamericanas se caracterizaron y se formaron en su lucha por el poder y en tal lucha fueron agregando ideas y conceptos de Europa, lo cual deja entrever de manera sencilla que, por más que sean élites que surgieron en la Nueva Granada y que se quedaron como latinoamericanas, no dejan de ser universales. 


\section{Capítulo III}

\section{Élites de poder en Nueva Granada}

Partiendo de la necesidad de aclarar que, el concepto de élite está sujeto a la escala de poder, es necesario recoger las apreciaciones históricas que sobre este concepto atañen a los países de raíz latina en su lengua, dentro del continente americano. Con el fin propuesto, es indispensable resaltar el concepto de élite desde la visión normal, el cual se refiere a un nivel de poder por poder, donde cuenta la historia de los poseedores de dicho concepto y sin duda su posición, económica, cultural, intelectual y política.

La élite, desde este sentido, es tomada como el máximo escalón de la pirámide social, es decir, dentro del concepto de élite no es válido hablar de círculos sociales. Esta apreciación que denomino corriente, resume las luchas ideológicas sobre el concepto, lo cual queda claro en lo manifestado por Peter Waldmann en el texto, Élites en América Latina, allí plantea las opciones de la élite. Por una parte, la opción de un concepto de élite por mérito y, al mismo tiempo, el poder de las élites por el origen social de quienes las ostentan.

Ya a principios del siglo XIX ciertos círculos vuélquese habían destacado que lo que faltaba era una élite de méritos y no una clase dirigente que legitimaba su posición privilegiada por razones de sangre o méritos militares de sus antepasados, sin embargo, los clásicos insistieron en que la minoría que tiene las riendas del poder político en sus manos en cualquier sociedad debe su excelencia no solo a capacidad y virtudes individuales, sino también a su procedencia social (Birle, Hofmeister, Maihold, Potthast, 2007, p. 10). 
Con lo anterior, queda sustentado que el concepto de élites emergió y se mantiene bajo un concepto dividido, al cual los mismos autores le agregan otra teoría basada en las dos visiones, por una parte, la visión clásica donde se hacía notable la homogeneidad de la sociedad y la visión moderna donde se hace patente la diversidad de la sociedad y su división por clases.

Estas dos posiciones han generado la dispersión del concepto de élite, al punto mismo que, la discusión se centró en dicho término, relajando el término gente que, comparado con el término élite, es inferior, lo cual es también tratado en el texto de Waldmann, donde se habla que el tema de la élite ha tomado tanto vuelo que, el resto de personas, que son mayoría y no hacen parte o, no caben en dicho concepto, son llamadas como masas, desligándolas, de alguna manera de la élite. El autor insiste en la necesidad de no separar los conceptos, pues son complementarios: "las masas y las élites no son entidades separadas; sobre todo en sistemas abiertos y democráticos, hay una fuerte fluctuación entre ambas” (Birle et al., 2007, p. 15). Esta fluctuación se da porque las élites no representan un universo individual de sociedad, sino que, por el contrario, las mismas élites son diversas pues "las élites representan de cierto modo los diferentes sectores del pueblo" (Birle et al., 2007, p. 16).

Al representar al componente del pueblo, es decir, de la sociedad en general, las élites son y han sido fundamentales en el cambio social, ya sea por oponerse al cambio y mantener estancada a la sociedad o, porque las élites hacen procesos casi imperceptibles que, con el pasar del tiempo, se hacen notables en los avances de la sociedad. Con ello, las acciones del concepto élite dentro de la sociedad están bajo la división del concepto, como tal, pues no es visible una posición que determine un hacer propio y universalizaste de las élites. Todo ello influye de manera directa en la política y la función de la élite, élite que en la política no es diferente a su 
historia, pues también entra en función de dos elementos: la política en el hacer y la política en el trasformar lo ya hecho.

El concepto de élite se relaciona con el concepto de democracia, términos que a simple vista son antónimos, pues élite se refiere a la individualidad y democracia a la colectividad, sin embargo, estos dos términos no se separan, al contrario, el concepto de élite, según el autor, es el que hace la labor de unificar las mismas divisiones que dentro de la democracia se dan. Así pues, la élite es un concepto que, en relación con otros, genera uniones y acuerdos precisamente por el poder que esta engendra, dado que las élites, de alguna manera, por ser grupales evitan la caída de la democracia, en cuanto no permiten el surgimiento de personas que individualicen el Estado, ni el gobierno: “constituyen la barrera más eficaz para impedir que líderes autoritarios monopartidistas tomen el poder" (Birle, et al., 2007, p. 19).

Todo el tratamiento anterior del concepto y relación de las élites, sentado al contexto latinoamericano, deja claro que la élite latinoamericana es particularmente especial, pues es una élite política basada en lo económico, que maneja un discurso agradable a las mayorías "masas" no con fines altruistas, al contrario, con fines de interés; interés en mantener su poder y que aquellos que se ven beneficiados, las mayorías, no denoten su interés. El autor manifiesta que las élites latinoamericanas se han visto sometidas a pruebas de fuerza por grupos sociales que buscan un cambio de estructura, grupos que, aunque son fuertes, no han logrado debilitar la élite ya establecida; al mismo punto que muchos de estos grupos alcanzan cierto poder y, en lugar de tomar la opción de la independencia, se unen a las élites ya existentes. Esta situación hace que las élites latinoamericanas sean una élite abierta con fines exclusivos de mantenerse. En conclusión, tales luchas contra las élites han sido estériles. 
Dos elementos son de resaltar dentro de la incoherente élite latinoamericana y su relación con el poder. Por una parte, la fuerte influencia de la Iglesia como principio rector de la moral y del hacer mismo político; otra, el alto nivel de corrupción dada la deprimente formación de los que ostentan el poder o incluso, de aquellos que luchan contra lo establecido. El resultado final de lo anterior, según Waldmann, es la inestabilidad política y pérdida de creencias en los elementos religiosos que, ahora son más bienes de manipulación que de principios democráticos o políticos, lo que conlleva a un nivel de desigualdad general: "se ha obcecado con razón que en condiciones de extrema desigualdad social, como son las características para muchos países latinoamericanos la democracia que se basa en la igualdad de los derechos tiene dificultades de arraigarse" (Birle et al., 2007, p. 32).

Finalmente, las élites latinoamericanas no se pueden unificar en criterios y en formas de aplicación, pues han existido cambios políticos sociales y económicos que, para algunas élites, han sido favorables y para otras no tanto; es así, como las élites latinoamericanas se han visto sujetas a los cambios que, en cada contexto y en cada país, se han venido dando durante los últimos años.

La primera consideración y, tal vez la que unifica el concepto de élites en América Latina, es la influencia de los Estados Unidos sobre las élites latinoamericanas. Walter y compañía manifiestan que las élites latinoamericanas se han formado con características clásicas y no con teorías modernas, además de que son relativamente nuevas en su independencia (Birle et al., 2007, p. 27). Esta teoría la sustentan en una comparación necesaria con Europa, debido a que la revolución industrial en América Latina fue tardía, en cuanto que los países latinoamericanos o mejor, los países de América asimilaron la industria mucho después que Europa, a excepción de Estados Unidos. Los países latinoamericanos eran economías agrícolas, 
lo que no es despreciable, pues de alguna forma, fueron los Estados latinoamericanos, los representantes de este tipo de economía a finales del siglo XIX e inicios del siglo XX; sin embargo, varios países emergieron con la industria y formularon unas élites más comunes a la modernidad, como fue el caso de México, Brasil y la misma Argentina. Por otra parte, una gran mayoría de países latinoamericanos aún se aferran a los medios de producción antiguos y la industria ha entrado con mayor resistencia; esta situación se expone en el texto como una justificación para la inestabilidad de las élites latinoamericanas y el surgimiento de ciertas pseudoélites como en el caso de Venezuela, Ecuador y Bolivia, denominados países andinos, lo que ha conllevado a que el crecimiento económico social y político sea necesariamente dispar en la generalidad de Latinoamérica: “América Latina ha tenido un desarrollo socioeconómico muy desigual según de que país se hable" (Birle et al., 2007, p. 28).

El texto también resalta que tal inestabilidad no ha variado, pues países que al parecer habían asumido una élite definida, hoy por hoy, se han ido transformado a élites renovadas como es el caso del Brasil y la política emergente de PT (partido de los trabajadores), el cual ha generado varios órdenes que van en contra de la universalidad de las élites. En este aspecto, tal universalidad de las élites está fundada en la variedad política y la estructura social que la globalización ha impuesto.

América Latina se ha visto abocada a un sin número de conquistas tanto políticas, como culturales y económicas, pero una de las conquistas que más fuerza hizo en la historia es la conquista intelectual.

El primer gran paso de la intelectualidad en América Latina llegó con la conquista, en este caso se dio con un intelectualismo religioso, el cual no solo se basó en teorías teleológica y metafísica, sino también en teorías humanistas, tal es el caso de Bartolomé de las Casas o el 
mismo Francisco de Vitoria, quienes fueron los grandes abanderados de la idea de crear una teoría sobre el nuevo mundo descubierto. La conquista espiritual e intelectual de las poblaciones vencidas a comienzos del siglo XVI, recayó exclusivamente sobre las espaldas de los miembros del clero católico y en muy particular sobre las del sector más propiamente letrado de la Iglesia. Estos sectores representados en las comunidades religiosas u órdenes religiosas como los jesuitas, los dominicos y los franciscanos, configuraron un cambio sustancial entre los que se concebía como creencias raizales y lo que, a partir de ahora, sería una creencia impuesta, basada en principios de conocimiento avanzado, que obligaba a demeritar el conocimiento indígena, el cual era visto como retrasado e incluso pecaminoso.

El hecho de que la sociedad española, habitante del nuevo continente, emergía a pasos agigantados, asumiendo el mundo viejo y derogando el mundo que habitaba, las tierras de América desde la antigüedad, implicaba la necesidad de la creación de las universidades con las cuales se equipararía la intelectualidad floreciente en Europa, con la naciente en América. El derecho fue la base que abrió el intelecto y el profesional del nuevo mundo, un mundo sujeto bajo las nuevas caras de las órdenes religiosas ya mencionadas. Con el pasar de los tiempos, llegó la comunicación como medio conocimiento. El periodismo, el periódico era el medio comunicativo y, al mismo tiempo, la puerta de la cultura, la cual estaba permeada del ambiente casi moderno e informativo, que reconocía al Estado como el eje central de la nueva forma de vida, al igual, aquel surgimiento necesario de una teoría económica: “el incremento del número de periódicos publicados y de su tirada [...] la lenta cristalización de un universo editorial articulado en torno a las leyes del mercado..." (Altamirano y Myers, 2008, p. 48).

Con el tiempo, y al paso del auge eclesial y cuando, de alguna manera, los del nuevo mundo asimilaban su ser, aparecieron los rasgos del nuevo intelectual latinoamericano, caso el 
poeta, el artista, el pensador, los cuales fueron los encargados de entrar en lo cultural y por medio de su arte, hacer historia y con ello, la aparición del historiador como el eje anunciador del posible futuro de los países latinoamericanos: “A partir de la década de 1830, un conjunto de tópicos discursivos enraizaba la "autonomía" del pensador del poeta, del artista en relación con las convenciones vigentes en su sociedad" (Altamirano y Myers, 2008, p. 39). Con la apertura del ideario, llega la literatura que deja de ser un acto de entretenimiento social, para convertirse en una profesión de grandes intelectuales, la cual tomaba la parte histórica y romántica de la realidad vigente para cada época: "La literatura en vez de ser un simple pasatiempo [...] era defendida como una práctica noble y exigente” (Altamirano y Myers, 2008, p. 48).

Ahora bien, todo este proceso que se abre con las puertas del ambiente religioso no se dio solo, el texto menciona permanentemente la influencia de Europa, en particular de Francia y, su ejemplo revolucionario en todo, incluido lo literario. El nivel intelectual, en cuanto a los ambientes literarios, se insiste, no estaba delegado a una acción simplemente recreativa, Latinoamérica reconocía en ello un arte y, por tanto, una acción creadora, llena de elementos técnicos que solo era posible para quienes contaban con una instrucción necesaria para lograr el cometido, el cual no era otro que hacer parte de esa gran élite intelectual de la época.

Esta nueva élite fue más allá de las creaciones fantásticas que la literatura permite, sino que se dio paso a nuevas ciencias, a nuevos saberes tales como la lengua. El español había sido determinado como el idioma dominante y el que permitía una comunicación real y, por ello, era necesario generar unas normas que lo rigieran y le dirán el valor y el orden de lengua madre. De allí se creó la gramática de la lengua española, la cual no solamente fue novedad en América, sino que también, fue la primera en España como nos lo relata el texto, teniendo en cuenta que, el español es la lengua que también define a las élites: "la cristianización de los indios, análoga a 
su hispanización, no supuso en una primera época el aprendizaje del español sino por parte de las élites" (Mazín, 2007, p. 165.).

Los géneros literarios surgieron de manera paralela al proceso de la lengua española, junto con ello, el derecho como ciencia humana y la teología como ciencia religiosa, junto con una filosofía escolástica, daban cuerpo a la nueva intelectualidad de élite de la sociedad latinoamericana. De lo humanista, también se pasó a lo científico, la química, la astronomía, la matemática, la historia natura, la cartografía, la geografía, la minería y la metalurgia cobraron un valor relevante; es necesario tener claro es que estas ciencias, en su práctica, seguían bajo los preceptos religiosos y bajo su peramente vigilancia.

Las ciencias aquí expuestas fueron parte de la configuración de la modernización de América Latina y a su vez, parte del surgimiento de las élites en Latinoamérica, esto sin perder la influencia de la Europa conquistadora. De allí que, no es para menos que donde habitaron grandes culturas indígenas, que poseían una civilización fuerte y con principios arraigados, los españoles o, mejor, los europeos profundizaran sus acciones intelectuales en estos lugares. Tal es el caso del Perú y Brasil. En el primero, la generación de la academia como sitio de intelectuales y, de alguna manera, como una manera de separar esa élite del común de las gentes, pues genera un reconocimiento frente a los poderes existentes para la época: "La existencia de la academia da prestigio a una ciudad o a una región, la legitima y le depara un lugar en el mapa letrado imperial" (Altamirano y Myers, 2008, p. 86). Este lugar de reconocimiento no deja de ser otra cosa que, una manera de hacer visible a la élite en dicho país y, a su vez, es la demostración de un dominio absoluto sobre el que, otrora, fue un imperio indígena.

En el caso de Brasil, la literatura y la intelectualidad buscaron hacer posible la remembranza de su pasado, es decir, no fue una intelectualidad encaminada a favorecer al 
conquistador, sino a dar prevalencia a su pasado, igual no deja de ser una élite que se encarnó en lo cultural y generó una existencia propia: "Los letrados del nuevo paso se empeñaron en buscar en el pasado los elemento que mostrasen las raíces de una identidad nacional" (Lemperiere, p. 248).

En comparación, por el lado del Perú con España, por el lado de Brasil con Portugal, los dos tomaron caminos diferentes, la influencia de España hizo que el país inca tomara una alternativa de mostrar a España en su poder de dominación, mientras que Brasil asumió una posición de más de identidad. En los dos casos, las élites funcionaron de acuerdo a los intereses que para el momento se estaban dando y, con ello, fueron tomando forma, esta forma que hoy nos da paso incluso para hacer análisis sociopolíticos.

Tras la independencia, llegó la fuerte influencia ilustrada de Europa, en particular de Francia. Con ello, llegaron los nuevos intelectuales que tenían una raíz forjada en el territorio donde hacían literatura y sus ciencias y, quienes no se limitan a hacer visible el universo del conquistador, sino que poseen ideas diversas con teorías nuevas, que retan a la imaginación del nuevo latinoamericano. Algunos de ellos vieron la necesidad de defender la independencia de América como una oportunidad de surgimiento y de nuevas ideas. Tal es el caso de Fray Servando Teresa de Mier, quien no solo era un hombre intelectual, sino que también, era un miembro de las altas élites mexicanas y quien se relacionó con Simón Rodríguez, el maestro de Bolívar y con el cual formó una amistad de intelectos y de enseñanzas. Junto con este personaje, aparece Antonio Nariño, quien se le da el honor de promover los derechos del hombre y enfrentar a un mundo aun españolizado y catolicista, poniendo por encima de ellos al hombre como individuo de derechos. 
Estos hombres y otros tantos que la historia nos deja, fueron significativamente relevantes para la historia, pero junto a ellos, la ciencia aportó elementos que les permitieron hacer su nombre aún más grande. Tal es el caso de la imprenta, la cual permitió a Nariño hacer más visibles sus ideas y, en parte, lo positivo de Europa, con la impresión de los derechos del hombre. De igual forma, que esta herramienta ha ayudado a la generación de los nuevos periódicos que fomentaron la intelectualidad y la necesidad de expandir la educación más allá de las clases sociales altas y, al mismo tiempo se genera un ambiente publicitario que hace posible identificar los servicios que para la época se ofrecían.

Finalmente, todo lo visto no fue más que todo un proceso de intelectualización de América, desde las humanidades, hasta las ciencias. América recogió elementos que le permitieron crear una identidad propia e ir formando una élite que, aunque no está diseñada totalmente, tiene ya, unas bases objetivas; al mismo tiempo, América, aunque continua en dependencia de Europa en ciertos aspectos, tiene un carácter más propio, no del gusto de todos, pero necesariamente reconocible de quien nos ayudó a dar tal forma como fue Bolívar.

En América, surge una nueva sociedad y con ello, unos nuevos intereses. Tales intereses estaban fundados en los recientes hechos que a nivel global se sucedían y que, de alguna manera, cambiaban la estructura social predeterminada desde la conquista. Una sociedad revolucionada en el mundo.

La independencia de Estados Unidos, la revolución francesa y la actividad partidista de los comités de propaganda, el conflicto de la corona con los jesuitas [...] "la creciente insatisfacción de algunos cenáculos del poder por las medidas adoptadas en el espectro económico y político fueron algunas de las causas que motivaron el temor de las repercusiones que se podían derivar de ellas" (Peralta, 2005, pp. 2-3). 
La división entre nativos españoles y los llamados criollos, es decir, aquellos de sangre española nacidos en el nuevo mundo, ya estaba clara en todos los aspectos, tanto en el económico, como en el político, pero la división mayor estaba en el político, la élite dominante eran los españoles de sangre pura "de treinta y dos nombramientos para puestos de audiencias solo nueve fueron conferidos a los criollos" (Peralta, 2005, p. 3).

Esta división de poder no era una división caprichosa, se trataba de mantener una estructura de pureza, donde quien manejara o representara a la corona española, tuviese un vínculo inalienable con España, de sangre y de casta, quien no lo tuviese se convertía en criollo americano y esto le indicaba menor posibilidad de progreso y poder dentro del nuevo mundo: "Una forma de probar los méritos para poder ejercer la profesión en las reales audiencias, era la práctica de adjuntar con las solicitudes la prueba de nobleza y origen legítimo de los aspirantes, así como la descendencia de una noble casa de la genealogía española.” (Fortich, 2011, p. 153).

Si bien es cierto, esta forma de selección era para los letrados o juristas de la época, era la base para todos los otros cargos públicos, lo cual, sin duda, desestimaba y menospreciaba el hecho de haber nacido en el nuevo mundo y, en parte, desconocía el puro y neto origen español. Por una parte, los criollos buscaban su independencia, mientras que los españoles se resistían a que esta se llevara a cabo, el virreinato se desarrollaba entre la libertad y la imposición. Este segundo, aspecto proveniente de España, fue el que prevaleció. La idea era controlar a los que deseaban independencia y, para ello, era necesario tomar cartas en el asunto, de allí que la fuerza militar representara el poder monárquico: "La entrega del mando entre los virreyes Espoleta y Mendinueta realizada el 3 de enero de 1797, en Cartagena, certificó la vigencia de esta política" (Marín, 2008, p. 27). 
Las dos situaciones conjuntas, junto con la represión constante del viejo mundo sobre aquellos que surgían en el nuevo mundo, generaron las fuertes revoluciones y la organización de una nueva sociedad en América. El descontento de parte de los criollos aumentó de manera significativa entre 1780 y 1810 , al punto de que ya no era una situación de simples marchas o comentarios de corrillos, sino de enfrentamientos entre las milicias establecidas por los españoles y las milicias nacientes en el nuevo mundo. Estas luchas, España las mantuvo al margen de sus políticas, pues tales situaciones estaban dadas por razones de castas, realmente una organización fuerte que lograra desestabilizar el poder español. Esta desatención hizo que se dieran movimientos comuneros como el caso de Colombia, que logró generar un cierto temor a los españoles, quienes respondieron con la negociación y dada esta, con la persecución.

El ahogamiento de estos movimientos no cumplió con la idea de pagar la idea independentista y la necesidad de una nueva élite reconocida por España, por el contrario, dio fuerzas para que dicha sociedad criolla generara una nueva élite. Tal élite, como lo manifiesta Jaime Andrés Peralta, tenía como base de reconocimiento, el poder económico, es decir, quienes tenían un pulso económico suficiente, podían gobernar tal fuerza de élite naciente, "una élite colonial se definía como aquel sector de la sociedad poseedor de tierras, de explotaciones mineras y de grandes circuitos comerciales" (Peralta, 2005, p. 5).

Frente a esta nueva sociedad naciente en América, los españoles, encabezados por su rey, Carlos IV, tomaron medidas, que proporcionaban mayor vigilancia sobre el nuevo mundo, con el fin de mantener el poder de España sobre América. Entre ellas, se resalta la creación de nuevos cargos que quedaron en manos de los españoles puros y por otra parte, la regulación del tránsito económico y de productos entre el viejo y el nuevo mundo, todo ello bajo la mirada atenta de unas nuevas estructuras con funciones de vigilancia y seguridad, "la creación de nuevas unidades 
administrativas para tener controles más directos de los inmensos territorios, el fortalecimiento de los cuerpos de milicia al servicio del rey y no de los grupos de poder americano" (Peralta, 2005, p. 12). Esta situación fue más allá, llegando al punto de eliminar, incluso, algunos derechos adquiridos por parte de los españoles americanos.

Los españoles administraban, pero a su vez veían que su potencial militar y de orden no les era suficiente, las élites sociales que representaban al viejo mundo en el nuevo mundo, se veían amenazadas por la resistencia de los criollos, una élite naciente y que deseaba el poder, la fuerza militar que también era otra élite, fue cambiando sus estrategias para entrar de manera más puntual en la población renuente a aceptarlos. El nuevo virrey abrió las puertas a otros pensamientos sin darles total cabida en los asuntos de Estado, pero sí, generando nuevas posibilidades de pensamiento: "el gobierno de Mendinueta se distinguió por la ausencia de conflictos reseñables y la buena sintonía con los miembros de las principales instituciones santafereñas" (Marín, 2008, p. 33).

De la militarización, la cual no perdió su auge, a la cercanía social. Esta situación permitió que la sociedad o élite santafereña tomara nuevos impulsos y, al mismo tiempo, nuevas formas de ver la realidad que sobre ella se desarrollaba. Tras todas las luchas y devenires anteriores, surgieron los novatores, los cuales, si bien es cierto estaban consignados en un término de poco aprecio, fueron quienes dieron inicio a una nueva idea de pensamiento y por qué no decir, de ilustración. Con ellos, las élites no estaban sujetas solamente a lo económico y a lo social, sino que también, entraban a lo intelectual. Este último nivel permitía visualizar una nueva sociedad que iba más allá de lo que parecía ser una élite: "los postulados del universo ilustrado a medio camino entre viejos esquemas y las nuevas realidades bastan para revelar sutiles alteraciones en los cánones que sustentaban la estructura social" (Peralta, 2005, p. 20). 
La Nueva Granada asumió lo que de Europa venía, es decir, las experiencias y los aportes de los novatores en cuanto a la concepción del mundo de la literatura y demás aspectos. Generó también cambios sustanciales, no solo en las ideas, sino en los comportamientos de los criollos americanos, los cuales, a partir del pensamiento novator, no solo analizaron el recorrido de su historia, sino que también, a partir de su realidad presente, analizaron la posibilidad de un futuro con cambios sustanciales.

Las ideas de los novatores fueron las que a la postre, cambiaron la noción de apego a España y la idea de que América era el componente de un nuevo mundo, con nuevas ideas y que podía extraer ideas de Europa, para lograr la igualdad con el viejo mundo; muestra de ello, la traducción de los derechos del hombre por parte de Antonio Nariño y el memorial de agravios de Camilo Torres, texto que vislumbra la idea ilustrada y de cambio que en el nuevo mundo emergía y, que se apoyaba en los medios que para la época existían:

La prensa como vehículo principal de difusión [...] le dio cabida a todas las corrientes de pensamiento ilustrado [a excepción, tal vez, de las vertientes más radicales concernientes a la vida política que se difundieron en pasquines] y sus páginas fueron fiel reflejo de la evolución con sus avances y contradicciones" (Peralta, 2005, p. 64).

El uso del medio de comunicación para la publicación del pensamiento no era suficiente, pues, si bien es cierto era una herramienta funcional era restringida, debido a que no todo el mundo tenía la capacidad de entenderla, dada la falta de educación, es así como el periódico y demás medios escritos fueron un bien de la élite letrada e intelectual, para ellos mismos. La élite letrada era compuesta. Por una parte, los letrados realistas, es decir, aquellos que tenían su intelecto en los libros y las leyes y, por otra, los letrados religiosos, los que conocían la literatura concerniente a la situación clerical, su posición los distanciaba por su concepción, sin embargo, 
también los unía en cuanto a sus objetivos, que no estaban más allá de ser la obediencia al virreinato, lo cual detenía de manera sustancial, el interés de la independencia: "hay una posición regalista y regalista ortodoxa de algunos hombres de élite en el virreinato que fue obstáculo para las revoluciones independentistas y para una verdadera formación de una comunidad de ilustrados" (Fortich, 2011, p. 162).

Lo anterior deja entrever que la élite intelectual que surgió en el nuevo mundo, en principio no se dio del lado de la independencia, más allá de las inconformidades que estos tuviesen con la corona, lo real es que esta élite dio pasos para mantener el poder de manera personal y en bien de la realeza. Así pues, el origen de los novatores y de los letrados que defendieron la independencia o que, por lo menos querían un reconocimiento más amplio para sus gentes, se dio con aquellos que vieron la posibilidad de crear un nuevo mundo a partir de leyes e ideas propias, sin tanta injerencia de España.

La realidad de América con estos personajes que constituían las élites, ya fuera a favor o en distancia de España, era que, en el fondo, tenían claro un principio, que correspondía a implicación simbólica del rey, es decir, entendían que no solo se estaban oponiendo a un esquema, sino a una figura que en sí, era un hombre con una alta representación divina o mejor, un hombre casi Dios, idea que era fomentada por el principal orden rector de la época que era la Iglesia. Este poder del rey no solo justificaba la ley, sino que también justificaba la existencia de una escala social, donde los criollos no eran más que los afortunados por tener algo de España.

Es aquí, donde el elemento religioso también entra en la formación, tanto de la élite como de la sociedad del nuevo mundo: "El poder del rey estaba legitimado en un orden espiritual, coadyuvado por la iglesia al tiempo que estaba respaldado y vinculado al saber jurídico en el que confluía su potestad temporal" (Fortich, 2011, p. 75). 
Así, con esta consideración, no podía quedar por fuera de este recorrido, el elemento religioso y su forma de entrar en los idearios de los pobladores de la Nueva Granada, lo que hacía que el proceder de la sociedad estuviera más encaminado a lo espiritual que a la ciencia; para la época, era necesario darle un cambio así que se presentó una nueva idea, que concierne a los elementos filosóficos; la intención era simple: lo clásico es decir, la escolástica debía evadirse y asumirse un conocimiento más racional, en otras palabras, menos fe, más razón: Como forma de conocer el mundo su espíritu estaba tenido de religiosidad. Por ello su tema fundamental fue la relación de la teología con la filosofía dando por lo general primacía a la primera sobre la segunda. De este proceso de reflexión madurado durante siglos surgió un cuerpo doctrinal en el que a la fuerza quedaban justificados todos los elementos de una cosmovisión que aceptara y fuera enteramente compatible con la revelación, la vivencia y la tradición cristiana. Todo lo que saliera de este parámetro se descartaba y proscribía" (Peralta, 2005, p. 71).

Esta posición de tomar como elemento no considerable la idea de la escolástica, generó nuevos cambios y nuevas acciones necesarias para la generación conocimiento, el método escolástico ya no tenía razones de existencia, de allí que se asumieron nuevos posicionamientos intelectuales que, sin duda, eran conocidos por las élites sociales y económicas, pues dado su bagaje intelectual, podía proponerlos como posibles y como válidos. "Los ilustrados de la Nueva Granada se mostraron [...] partidarios de la razón, pero apostándole mayormente a la razón Newtoniana" (Peralta, 2005, p. 79).

La aplicación de los métodos diversos distantes de la escolástica, no solo hizo que los ilustrados vieran una sociedad nueva, sino también, que notaran dos aspectos relevantes. Por una parte, la realidad en que vivían los habitantes del nuevo mundo, es decir, aquellos que están lejos 
de las élites, situación que no era otra que la de pobreza absoluta, situación fundada en la corrupción y en el mal manejo de las riquezas primigenias de los territorios. Tal corrupción se veía en el abuso de los poseedores del poder, pues disponían de los movimientos comerciales entre las regiones y en tanto, no formaban ningún medio posible para generar progreso, de allí que fue necesario que, la razón se llevara al nuevo hombre o mejor, al hombre del nuevo mundo, a priorizar elementos que permitirían el desarrollo de los virreinatos: "En el plano interno las malas vías de comunicación fueron señaladas como un obstáculo de primera magnitud para el progreso del virreinato" (Peralta, 2005, p. 86).

Es así, como la función de varios círculos sociales, no solo generó cambios de idearios, sino también, cambios sociales, económicos y políticos, lo que permitió que los llamados novatores, no solo se restringieran a una acción intelectual de análisis y critica, sino también a la idea de proponer nuevas ideas prácticas para el progreso social: "los novatores no solo presentaron críticas, sino soluciones con miras a sacar la colonia adelante" (Peralta, 2005, p. 88). En las discusiones que se tejían, unos abogaban por mantener el sistema económico basado en la dependencia, este grupo era menor, otros sometían la economía a la producción agrícola y otros, veían el camino en las manufacturas, en fin. El virreinato de la Nueva Granada estaba formando un medio contertulio de ideas que, en la práctica, solo eran posibles en la medida de que se dieran nuevas propuestas políticas.

Tales discusiones, de las cuales surgían nuevas propuestas que podían tener buena ruta dentro del virreinato, surgían de personas que tenían un conocimiento de la realidad y también, que tenían un bagaje literario y de conceptos, que podían aplicar a la práctica. De allí que estas personas, se identificaban como otra élite, como otro grupo reducido de personas con un bagaje intelectual, que formulaba nuevas ideas y que, de alguna manera, daba cuerpo político al nuevo 
mundo. Estos letrados, por sus características, eran los predilectos frente a los criollos para ocupar los cargos en el nuevo mundo, de allí que, además de generar idearios e intelectualidad, también eran causales de división, pues los criollos estaban siempre por debajo de su posibilidad de poder: "No era fácil el acceso a las plazas públicas, en tanto, los criollos no eran preferidos para dichos puestos, salvo notables esfuerzos que debían ser refrendados en las famosas relaciones de méritos y circunstancias" (Fortich, 2011, p. 149).

La historia social, la influencia de España, el descontento de los criollos, las esporádicas revoluciones, los grupos sociales con poder económico, las nuevas mentes que partir de la razón formaban intenciones de cambio y con ellos, modificación económica y social, no eran suficientes ni un orden de leyes y de políticas, para los ilustrados o novatores, la política no era un tema de simple discusión o de ubicación de piezas, era una acción que iba más allá del concepto, era una acción que tenía que ser ilustrada. Una categoría que estaba sobre las demás, “el arte de la política lo llamaron y como tal lo definieron como el de "hacer de los espíritus de la nación unos solo" (Peralta, 2005, p. 100). Es decir, hacer una sociedad homogénea, en la cual, la política sería el máximo nivel para que todo el virreinato lograra los demás cometidos, tanto sociales, como económicos.

Como ya se manifestó, la política dentro del concepto novator no fue un hecho de simple práctica, sino de reflexión, reflexión que se dio desde varias aristas relacionadas con el total de lo que concernía el virreinato. Uno de los aspectos fue la discusión entre lo privado y lo público. Frente a estos dos conceptos, se dio una amplia discusión semántica, siendo relevante el de sentido público, lo cual convergía con la idea de que todo era uno:

Lo público fijaba límites a las apetencias deseos y actos individuales, dirigía las voluntades particulares, canalizaba los esfuerzos personales, trazaban determinados 
acuerdos y prefiguraban un cuerpo de reglas que debían ser acatadas por los diferentes estamentos para que el cuerpo social funcionara en paz y armonía” (Peralta, 2005, p. 101).

Esta rama de la realidad virreinal, tenía varios ingredientes, entre los que se resalta el papel de los juristas. Estos personajes eran el resultado de una educación formada para el desarrollo de la política, las leyes. Sin duda, los juristas hacían parte de la clase o élite letrada: "Los juristas como gremio han estado vinculados de manera decisiva a las élites políticas de las sociedades donde se desarrollaba su oficio" (Fortich, 2001, p. 145).

La política tenía, ahora, que tomar el aspecto de la obediencia al sistema impuesto o la libertad de la cual tanto se habla en la ilustración. La autodeterminación, concepto exógeno de los novatores, su respuesta fue opuesta a sus proclamas, pues entre telas, se mantuvo la idea de que las leyes estaban encumbradas en unas normas establecidas desde España y que, el virreinato debía acogerlas como propias; sin embargo, era prudente darles a los ilustrados y a las clases sociales altas, una visión diferente. De allí que la ley que sometía, solo era aplicable para el común mientras que, para las altas castas, se podían generar algunas variaciones: "Fuera de las élites, los demás miembros del todo social siguen siendo tenidos en cuenta por los ilustrados tan solo como "castas", como simples actores colectivos sometido a su tutela" (Peralta, 2005, p. 106).

Con lo anterior, un gran proyecto con agentes propios, generó más inestabilidad que unión, pues los ilustrados, los que usaban la razón, los que degradaban los principios religiosos y humanistas, los que hablaban de la liberta autodeterminación, ya habían determinado cómo la sociedad se dividía. Esto dio pie a descontentos, pues simplemente, la discusión que parecía generar cambios, retornaba a la idea natural de los conquistadores: "el poder monárquico, las 
instancias de los gobiernos locales, dirigidas por las élites regionales" (Peralta, 2005, p. 113).

Estos descontentos hicieron que los novatores accedieran, de alguna manera, a ciertos cambios de ideario, pero ya su credibilidad estaba sujeta a sus nuevas propuestas, las cuales no dejaban de estar bajo la tutela de los españoles; de allí, que el lugar de los novatores no fue otro, que el de una cultura pensante que coadyuvó a la sociedad del nuevo mundo a pensar y crear un nuevo mundo. 


\section{Conclusiones}

Después de generar una disertación abierta al diálogo y a la discusión, es primordial relatar las relaciones intrínsecas entre el poder la élite y su función histórica y presente en América Latina, más allá que esta sea o no traumática para nuestra dignidad frente a los hechos que la historia nos refleja. A partir de ello y como forma de posible conclusión se puede afirmar que:

El recorrido de la investigación, el documento permite ver la dialéctica del poder y las élites, y cómo las élites a través de la historia han sido las gerentes y garantes del poder en todas sus aristas, tanto intelectuales como culturales, económica y políticas. Los pensadores y literatos en sus escritos formulan ideas que permiten el análisis de los dos conceptos tanto en su conjunto, como de manera individual. De allí que, el logro de la investigación traducida en la presente tesis, es la asimilación correlación y aplicación a la realidad propia de un universo de conceptos que formulan la realidad de nuestro ser como latinoamericano.

Es por ello que en cada uno de los apartados del presente informe de la investigación se hace una relación directa de América Latina con el contenido que ese estaba tratando, iniciando por la edad antigua: caso la visión mesopotámica, donde se menciona cómo el poder en la civilización mesopotámica, traspasó las fronteras de las épocas. El ejemplo que se cita es la división entre criollos y puros que se dio en la Nueva Granada, donde una clase favorecida, los puros españoles, dominaba y sometía a aquellos que habían nacido en la América, aun cuando tuviese sangre de la madre patria, situación que no fue diferente en la Mesopotamia antigua y 
nivel de las castas. Con ello se sustenta la conclusión de que ciertas estructuras de poder y de gobernabilidad, no solamente hacen parte de la historia, sino que también trascienden sobre ella.

La presente sustentación de esta conclusión se expande a la filosofía medieval ante todo aquella de carácter religioso y cómo esta forma de ver el poder fue aplicada en la Nueva Granada. Lo anterior sustentado en la posición de pensadores como Santo Tomas y San Agustín; sus pensamientos trascendieron, la idea del poder divino como fuente de gobierno, y la forma en que esta idea se mantuvo durante la época neogranadina, en particular, la fuerte influencia de la Iglesia, especialmente de la orden dominica, que fomentó los cambios políticos que se dieron en el nuevo mudo con la llegada de los españoles, haciendo creer a los habitantes del mismo que, el rey, por más que tuviese una figura humana, no era tan humano, pues estaba dirigido por la voluntad divina. No era difícil para los aborígenes asumirlo, pues sus mismos gobernantes tenían el mismo argumento, aunque con dioses diferentes. El nuevo Dios, representado en una cruz, infundía respeto, no por su bondad, sino por su acto de dar a su propio hijo de manera tan sangrienta. Los religiosos incentivaron al aborigen creer ciegamente en Dios y, por lo tanto, en el que lo representaba en especial, es decir, el rey, al punto que al no respetar estos mandatos, se caía en la herejía, la cual era castigada de manera drástica, mismo así con la muerte. Con el pasar del tiempo, la Iglesia continuó siendo el aval de las leyes y la herejía se mantuvo como delito. Si bien es cierto los tiempos cambiaron la etapa granadina, para América fue la etapa en que se vivió parte de la edad media europea, en cuanto a la visión de que el poder no era meramente humano, sino un acto divino.

Por otra parte, en cuanto a la época de la ilustración, este también provee un aparte del concepto de poder dentro de la realidad que se vivió en la Nueva Granada, puesto que ideas de 
varios de ellos entraron en las ideologías propias de aquellos que mantenían un descontento con la forma en que España dominaba a el nuevo mundo, en particular su estructura militar y de presión sobre la Nueva Granada, dado que ella mostraba indicios de poder y deseo de separación. Cabe tener en cuenta que quien más influenció a los americanos criollos fue Rousseau y su Contrato Social, el cual inspiró, sin duda alguna, los derechos del hombre y el afán de un Estado libre, de allí que el prócer de la libertad Simón Bolívar lo tomara como sustento teórico de su hazaña. De igual forma, los criollos ilustrados lograron su ilustración gracias a las teorías de estos pensadores, lo que implica y hace insistente la idea de que, los ilustrados permitieron un cambio ideológico en la América conquistada.

Finalmente se relaciona la élite europea antes de la conquista; dicha relación se establece basada en la economía y el intelecto de los letrados, los cuales por su conocimiento y poder se consideran con dones especiales y trasmiten tal ideología a quienes vienen a dominar a los habitantes del nuevo mundo. Con lo anterior queda claro que el poder y su función natural fue pasando a los habitantes del nuevo mundo, permitiendo así que la realidad actual sea basada en los poderes que al final son los que dominan las masas.

El recorrido bibliográfico hecho para lograr el corpus de la presente informe de investigación fue detenidamente seleccionado, de allí que, los argumentos aquí sustentados son de un amplio valor investigativo, pues componen la fundamentación de personas que han dedicado sus vidas a la búsqueda de elementos de cómo la sociedad se desarrolla en los diferentes espacios, algunos de ellos aquí mencionados como son el elemento del poder en la sociedad y las élites que estratifican a esa misma sociedad en la que hoy vivimos, sociedad apropiada por los latinoamericanos. 
Los conceptos de poder y élite en América Latina, son los elementos fundantes y primordiales de toda la investigación dada en el presente informe, estos conceptos asociados con nuestra América se entienden por separado y en su conjunto. Por separado, el concepto de poder es en sí mismo, una razón de la existencia de los latinoamericanos en el fin de emanciparse y gobernarse a sí mismos. Existencia y esencia que han buscado desde lo humano hasta lo divino. Por separado, las élites representan esos linajes ineludibles de nuestro pasado que históricamente han puesto sus nombres y apellidos, porque no decir, abolengos para formular en el latinoamericano unas castas que se ubican en las cumbres sociales y que desde allí estratifican al pueblo general.

En América Latina, los conceptos de poder y élite, vistos desde su conjunto, representan una simbiosis marcada en las superioridad de unos sobre otros, evidenciada en los campos culturales, económicos intelectuales y políticos de este continente, los cuales después de diversas divergencias, tocaron fondo y cumbre en la época de la Nueva Granada, cuando los criollos y los españoles de pura sangre se enfrentaron, los primeros por su reconocimiento y los segundos por su permanecía; esa lucha fue el reflejo de lo que la historia nos ha contado: las élites en acción por el poder.

De la misma manera que se ha concluido que el concepto de poder transcendió en la práctica y en lo ideológico desde la época antigua hasta la Nueva Granada y que aun hoy es notable sin mayores cambios, también aconteció con el concepto de élite, del cual se puede concluir que trascendió desde la edad antigua hasta nuestros días y cómo se vio influenciada la Nueva Granada por este concepto.

Como parte del sustento de la conclusión sobre el concepto de élite en la Nueva Granada, se puede afirmar que desde los inicios de la conquista los españoles tenían una escala social 
definida, esto a partir del concepto de "la sangre pura" que no era otra que aquellos españoles que nacieron en las casas de los grandes potentadas de la época, es decir, hijos de las sociedades más cercanas a los reyes o de familia de los reyes: los españoles de origen constituían la élite principal, luego la secundaban la Iglesia, militares de altos rangos y comerciantes, siendo estos últimos, la élite económica de la época. La llegada de esta escala de élites a el nuevo continente fortaleció su propio abolengo frente a los habitantes oriundos del continente americano, esto generó escalas más distantes, pues se concebía al español como la élite superior y única, siendo ella la que dominaba todos los aspectos de la vida dentro del territorio

Con el pasar del tiempo, los españoles dieron a luz a su prole en el nuevo mundo. Allí nació una nueva élite: la de los criollos. Dicha élite sería secundaria, y así se mantuvo durante la mayor parte de la Nueva Granada; sin embargo, con el pasar del tiempo asumieron una posición de reconocimiento como élite con mayor poder. Esta situación generó la primera lucha de poder entre las élites neogranadinas. La reyerta entonces se dio entre dos élites: la élite de origen, aquella que era española de nacimiento y que era cercana a los reyes y, la élite desarrollada en la Nueva Granada que estaba fundamentada en la posesión, en los bienes que habían adquirido por su relación consanguínea de los primeros españoles.

Con todo lo anterior, se entiende que el uso de las herramientas de poder basadas en la razón, evidenció que la forma más contundente de hacerse notar era estar en la élite y América Latina no fue ajena a esto. Como región geográfica, nació con una identidad cultural, religiosa y mismo así intelectual, lo cual le dio paso a una identidad de poder político y en tanto, a unas élites definidas; sin embargo, por medio de la fuerza y el engaño, unos agentes ajenos llamados conquistadores, generaron cambios sustanciales a la identidad y con ello, al poder y a la estructura de sus élites. 
Se reconoce que el poder de las élites en América Latina no es otro que la consecuencia de unos actos histórico que trascendieron el tiempo. Como queda claro desde la edad antigua, cuando la élite de poder estaba encarnada en la monarquía o en los dioses, donde los sabios representaban la élite intelectual y los comerciantes y feudales, la élite económica. Ya en la época medieval, la élite de la religión, los papas y los sacerdotes representaban a Dios: el todo poderoso que dominaba a la humanidad, que no era otra cosa que una esclava de dichos poderes. Con estos dos antecedentes, es claro que la unión de la élite antigua, que se relacionaba mas con lo monárquico y, la élite medieval que se relacionaba más el poder eclesial, formó un bloque de poder que trascendió hasta la época de la conquista y sin duda, a la etapa de la Nueva Granada que en este informe de investigación se prioriza.

La lucha entre estas dos élites se mantuvo sin dar un resultado de independencia ni de mayor poder al uno o al otro, así, el concepto de poder subyacente en las élites latinoamericanas, por ahora, es un concepto que carece de la identidad del entorno y está condicionado por la historia y la dominación generacional de las mentalidades e idearios que cada individuo latinoamericano va adquiriendo por diversos medios.

Se resalta el valor histórico que da la Nueva Granada a la propia historia de América Latina y a su antecedente: América Hispánica, pues, de acuerdo a todo lo investigado, esta etapa fue la de quiebre entre dos Américas. La primera, una América surgida de los conquistadores que se da a finales del siglo XV y que se va desarrollando de manera paulatina por todo el territorio de lo que para la época era un nuevo mundo; una América que no era América, sino una región ultramar de España y de otros países europeos que llegaron, como fue Portugal, Inglaterra y la misma Italia. Los habitantes de esta América no eran ajenos a una cultura, pues tenían varias que surgían de sus creencias y sus costumbres, pero sus propias mitologías ayudaron a que los recién 
llegados obtuvieran poder sobre ellos al punto del dominio, a esta se le llama la América hispánica porque el poder y la élite eran directamente españoles.

La segunda América es la América Latina. Es aquella que surge de las luchas comuneras, de las revoluciones independentistas, que tuvieron su nido en la inconformidad de los criollos por el trato que les daban los españoles de sangre. La lucha criolla permitió el surgimiento de una nueva sociedad que tenía claro que de Europa no solo los separaban las inconformidades del trato, sino también una geografía marítima inmensa y, junto con ello, el desgaste de España por los problemas internos y externos, tales como la revolución francesa que también los golpeó y debilitó para enfrentar las inconformidades que se daban en el nuevo mundo. Esta nueva América, se hace y se forma en medio de la lucha de los poderes tanto económico, políticos, intelectuales y culturales de un mismo mundo enfrentado entre sí por generaciones diferentes, la generación pura y la generación criolla.

Así pues, la Nueva Granada, terreno de esta lucha entre las dos Américas, fue también la que garantizó la configuración de la nueva sociedad americana desarrollada al sur del continente y fue esta, la Nueva Granada, la que sin duda vislumbró y nos dejó el concepto de poder y la formación de la élite en América.

Estas conclusiones delimitan y muestran el constructor general del informe de investigación y cómo los conceptos de élite y poder que en ella se trataron, se fueron relacionando de manera general, hasta llegar a una noción aplicable a nuestra América. Sin embargo, son tantos los espacios y la diversidad de elementos, que se pueden sustraer de la realidad latinoamericana que sería imprudente afirmar que en el informe se sintetizan todos los elementos, de allí que, el presente abre los espacios para nuevas discusiones y futuros planteamientos. 


\section{Referencias bibliográficas}

“Qué es el libre comercio?”. En El Diario Exterior. Recuperado de: https://goo.gl/BqnxUm

Altamirano, C. y Myers J. (2008). Historia de los intelectuales en América Latina. Argentina: Katz Editores.

Álvarez, J. y Puello J. (2005). Élites intelectuales y tecnocracia. México: Calidoscopio.

Álvarez, H. y Juaneda, R. (2014). Artículo El Príncipe.

Aristóteles. (1935). La política. España: Ediciones nuestra raza.

Aristóteles. (1985). Ética nicomaquea, ética eudemia. España: Editorial Gredos.

Ávila-Fuentemayor, F. (2007). Concepto de poder en Michel Foucault. Recuperado de: http://serbal.pntic.mec.es/ cmunoz11/avila53.pdf

Bachrach, P. (1967). Crítica de la teoría elitista de la democracia. Argentina: Amorrortu Editores.

Bajtin, M. (2003). La cultura popular en la edad media y el renacimiento. Argentina: Alianza Editorial.

Birle, P., Hofmeister, Maihold, Potthast. (2007). Élites en América Latina. España: Biblioteca iberoamericana. 
Blacha, L. (2005). ¿Élite o clase política? Algunas precisiones terminológicas. Revista Theomai. Argentina.

Bolívar, R. (2002). La teoría de las Élites en Pareto, Mosca y Michels. Recuperado de: https://goo.gl/qbQ18P

Buci-Clucksmann, C. (1987). Gramsci y el estado- hacia una teoría materialista de la filosofía. España: Siglo XXI de Espasa editores.

Casares, H. y Tezanos, S. (2010) Principios de Economía. España: Universidad de Cantabria.

Chuaqui, T. (2005). La ciudad de dios de Agustín de Hipona: selección de textos políticos. Recuperado de: https://goo.gl/X4GCos

"Concepto de cultura elitista". (2013). De De Conceptos. Recuperado de: https://goo.gl/diOF3L

Corporación Andina de Fomento. (2011). Servicios financieros para el desarrollo: promoviendo el acceso en América Latina. Colombia: Publicaciones CAF

Darwin, C. (2005). El origen de las especies. España: Ediciones Espasa-Calpe.

Díez, A. (2003). Élites y poderes locales sociedades regionales ante la descentralización. Perú: Ministerio Británico para el Desarrollo Internacional, DFID.

Dri, R. (1999). Teología política de Santo Tomás. Capitulo IV. Recuperado de: https://goo.gl/GI9MYs

Echevarría, I. (2012). Apuntes sobre la élite Cultural y la crítica. Revista UDP, (09). Recuperado de: https://goo.gl/80UdEM 
“Élite”. (2007). En Enciclopedia de la política. Recuperado de: https://goo.gl/pj5khY

Fernández, A. (2011). La teoría del Estado y del poder en Antonio Gramsci: claves para descifrar la dicotomía dominación-liberación. Nómada, revista critica de ciencias sociales y jurídicas.

Ferrán, B. (2007). Poder y felicidad: Una propuesta de sociología del poder. España: La Catarata.

Fortich, M. (2011). Togados y letrados. Libros, lecturas y bibliotecas en la formación de los abogados neogranadinos 1739-1777. Colombia: Universidad Libre de Colombia.

Foucault, M. (1995). Discurso, poder, subjetividad. Argentina: Editorial El Cielo por Asalto.

Foucault, M. (1999). Estrategias de poder. Obras esenciales, Volumen II. España: Editorial Paidos.

Foucault, M. (1992). Microfísica del Poder, España: Editorial La Piqueta.

Fuertes, M. (2002). Bases sociales de la emblemática: aristocracia y nobleza, pasado y presente. Revista Emblemata.

Gramsci, A. (1932). Cuadernos de la cárcel. Edición crítica del Instituto Gramsci a cargo de Valentino Gerratana.

Gramsci, A. (1971). El materialismo histórico y la filosofía de Benedetto Croce. Argentina: Editorial Nueva Visión.

Hessen, J. (2007). Teoría del conocimiento. Instituto latinoamericano de ciencias y artes.

Hobbes, T. (1961). El leviatán. México: Instituto nacional de estudios políticos. 
Homero. (1998). La Ilíada. Colombia: Panamericana.

Homero. (1944). La Odisea. Argentina: Editorial Losada.

Kant, I. (1784). ¿Qué es la Ilustración?

Kotler, P. Bloom, P. (1984). Mercadeo de servicios profesionales. Colombia: Fondo Editorial Legis.

Larran, J. (2006). Política y buen gobierno en la óptica de Santo Tomás de Aquino. En Revista electrónica de historias del OrbisTerrarum. Recuperado de: https://goo.gl/gkR0XX

Locke, J. (2012). Ensayo sobre el gobierno civil. Recuperado de: https://goo.gl/vDJcMt

Losada, L. (2005). Aristocracia, patriciado, élite. Las nociones identitarias en la élite social porteña entre 1880 Y 1930. Anuario IEHS.

Luhmann, N. (2005). El poder. España: Editorial Anthropos.

Maquiavelo, N. (1999). El Príncipe. España: Editorial Espasa Calpe s.a.

Marín, J. (2008). Gente decente: la élite rectora de la capital 1797-1803. Colombia: Instituto colombiano de antropología e historia.

Martínez, J. (2014). Montesquieu y la ciencia de la sociedad. Política y complejidad. Recuperado de: https://goo.gl/btWJh6

Marx, K. Engels, F. (2011). Manifiesto del Partido Comunista. México: Centro de Estudios Socialistas Carlos Marx. Recuperado de: https://goo.gl/iUXTmO 
Marx, K. (1987). El capital Tomo I; "El Proceso de Producción del Capital”. México: Siglo XXI Editores.

Mattick, P. (1975). Marx y Keynes, los límites de la economía mixta. México: Ed. Era.

Mattoni, S. (2005). El poder: Para una historia de filosofía política moderna. Argentina: Siglo veintiuno editores.

Mazín, Ó. (2007), Iberoamérica: del descubrimiento a la independencia. El Colegio de México.

Mills, W. (1987). Élite del poder. México: Fondo de cultura económica.

Montesquieu., (1906). El espíritu de las leyes. España: Librería general de Victoriano Suárez.

Muñoz, C. Valencia, M. (2012). La Élite del Conocimiento en la Sociedad Moderna: Intelectuales, Científicos y Profesionales. Recuperado de: https://polis.revues.org/4234

Palacios, L. Junco, A. (2000). Acércate a la historia 1. Del surgimiento del hombre y las guerras religiosas. México: Editorial Ederde.

Parkin, M. (2004). Economía. México: Pearson Editores.

Peralta, J. (2005). Los novatores. La cultura ilustrada y la prensa colonial en la Nueva Granada 1750-1810. Colombia: Editorial Universidad de Antioquia.

Platón. (1988). Diálogos IV La República. Madrid: Editorial Gredos s.a.

Real Academia Española. (2005). Diccionario Panhispánico de Dudas. Madrid. Recuperado de: http://lema.rae.es/dpd/?key= 
Reale, G. Antisieri, D. (2010). La ilustración Historia Del Pensamiento Filosófico Y Científico. Recuperado de: https://goo.gl/7JbKNR

Richet, D. Chaussinand-Nogaret, G. Gauthier, F. Robin, R. Soboul, A. Grenon, M. (1996). Estudios sobre la revolución francesa y el final del antiguo régimen. España: Akal editores.

Roche, P. (2010a). El pensamiento político en la edad media. España: Fundación Ramón Areces.

Roche, P. (2010b). Pensamiento medieval. España: Editorial Centro de Estudios Ramón Areces.

Rodríguez, D. (2005). Diagnóstico de procesos. México: Alfaomega.

Rousseau, J. (1999). El contrato social o principios de derecho político. Recuperado de: https://goo.gl/b9tyid

Sabino, C. (1991). Diccionario de economía y finanzas. Venezuela: Editorial Panapo.

Santo Tomás de Aquino. (1996). Tratado de la Ley, Tratado de la Justicia. México: Editorial Porrúa. Recuperado de: https://goo.gl/yO9xEH

Schröder, P. (2004). Estrategias políticas. México: Fundación Friedrich Naumann.

Subgerencia Cultural del Banco de la República. (2015). Macroeconomía. Recuperado de: http://www.banrepcultural.org/blaavirtual/ayudadetareas/economia/macroeconomia

Tragedias. (2001) V: Prometeo encadenado; Fragmentos de otras tragedias sobre Prometeo. Chile: Pehuén Editores.

Valdivieso, R. (2009). Teoría de las élites en el Diccionario Crítico de Ciencias Sociales. Recuperado de: https://goo.gl/LwUrgA 
Várnagy, T. (2000). El pensamiento político de John Locke y el surgimiento del liberalismo. Recuperado de: https://goo.gl/aM8hZn 